\title{
17. SEDIMENTATION IN THE MARSILI BASIN DURING QUATERNARY (ODP SITE 650, TYRRHENIAN SEA) ${ }^{1}$
}

\author{
Werner Hieke, ${ }^{2}$ Georgette Glaçon, ${ }^{3}$ Shiro Hasegawa, ${ }^{4}$ Carla Müller, ${ }^{5}$ and Jean Pierre Peypouquet ${ }^{6}$
}

\begin{abstract}
Twenty-three sediment intervals from top of Site 650 down to $510 \mathrm{~m}$ below seafloor have been studied. Their thicknesses vary between $0.25 \mathrm{~m}$ and about $40 \mathrm{~m}$. The studied deposits are turbidites or parts of them except one which is interpreted as an ash-fall layer.

The composition of the turbidites signalizes sources from shallow water/coastal areas as well as from deep water levels. Repeated mobilization and displacement seems to have been common.

Volcaniclastic material is the dominant component of the whole studied part of Site 650 sedimentary sequence. Ashfall deposits as well as normal open marine sediments are rare.
\end{abstract}

\section{INTRODUCTION}

This study was initiated by the onboard observations describing the lithology of Site 650 .

Most obvious is the abnormal thickness of the Quaternary deposits (about $570 \mathrm{~m}$ ) which indicates anything but normal open marine sedimentation. The frequency of graded sandy layers in the upper $130 \mathrm{~m}$ of the hole does not cast doubt on the occurrence of turbidites and their role in an abnormal sedimentation rate. However, there are also thick sequences of macroscopically homogenous sediments, the origin of which could not be explained immediately.

The problem of interpreting the recovered sediments becomes more complicated in Cores $650 \mathrm{~A}-14 \mathrm{X}$ to total depth, where we have a drastic decrease of recovery due to XCB coring. In this interval the number of graded sandy layers is much less than in Cores $650 \mathrm{~A}-1 \mathrm{H}$ through $13 \mathrm{H}$ (APC coring), whereas more or less homogenous sediments prevail. Therefore, the following questions arose:

1. Do the so-called homogenous intervals represent the upper part of turbidites the bases of which are sandy and graded?, and

2. If so, are we able to identify so-called homogenous intervals in the cores of bad recovery as parts of turbidites the bases of which are washed out by drilling processes?

3. Moreover, and naturally, where does the material of the turbidites come from?

A first set of samples was requested while on board to test the turbidite nature of sediments selected, on the supposition that they are representative of the problem. The study of this material showed that there are different types of turbidites as to

\footnotetext{
${ }^{1}$ Kastens, K. A., Mascle, J., et al., 1990. Proc. ODP, Sci. Results, 107: College Station, TX (Ocean Drilling Program)

${ }^{2}$ Lehrstuhl für Allgemeine, Angewandte und Ingenieur-Geologie, Technische Universität München, Lichtenbergstrasse 4, D-8046 Garching, Federal Republic of Germany.

${ }^{3}$ Laboratoire de Stratigraphie et de Paleoécologie, Université de Provence, 3, Place Victor Hugo, F-13331 Marseille Cedex 3, France.

${ }^{4}$ Institute of Geology and Paleontology, Faculty of Science, Tohoku University, Aobayama, Sendai, 980, Japan.

5 Geologisch-Paläontologisches Institut, Universität Frankfurt/Main, Senckenberg-Anlage 32-34, D-6000 Frankfurt/Main 1, Federal Republic of Germany.

6 Department Geologie et Oceanographie, Université Bordeaux, 1 avenue des Facultés, F-33405 Talence Cedex, France.
}

thickness, composition, provenance, and presumably triggering events.

From these first results, a new set of problems arose: Are we able to make a calendar of triggering events like sea-level changes, tectonic movements, and instability phases due to volcanism?

The following paper is a front-line report. The studies are not yet finished. However, some basic results can be presented.

\section{GENERAL INFORMATION ON SITE 650}

\section{Location and Initial Core Description}

Site 650 is located near the western rim of the Marsili Basin at $39^{\circ} 21.40^{\prime} \mathrm{N}$ and $13^{\circ} 54.05^{\prime} \mathrm{E}$ (Fig. 1). The water depth is $3516.3 \mathrm{~m}$ (echo-sounding corrected). The hole penetrated $602 \mathrm{~m}$ of sediments before entering basalt. The oldest sediments represent foraminifera zone MPl6 and nannoplankton zone NN 18 which means late Pliocene of an absolute age of about $2 \mathrm{~m}$.y (for details, see Shipboard Scientific Party, 1987).

Two lithologic units were distinguished on board (Shipboard Scientific Party, 1987):

Unit I: from top to Core $650 \mathrm{~A}-37 \mathrm{X}$ (0-354 mbsf), characterized by normally-graded sequences, low carbonate content (less than $30 \%$ ), episodic input of volcanic glass and pumice and high input of clay-sized terrigenous material. This unit has been subdivided by a "thick pumice layer" (Subunit Ib). Sedimentation rate: about $75 \mathrm{~cm} / 1000 \mathrm{yr}$.

Unit II: from Core $650 \mathrm{~A}-38 \mathrm{X}$ to Core $650 \mathrm{~A}-66 \mathrm{X}$ (354-602 mbsf), with higher carbonate contents as well as thinner and less frequent normally-graded clastic sequences and less volcanic detritus than in Unit I. Subunit IIa (Cores 650A-38X through 57X): predominantly calcareous mud (mean carbonate content $15 \%$ $20 \%$ ). Subunit IIb: predominantly nannofossil ooze (mean carbonate content $35 \%-40 \%$ ). Sedimentation rates: about $25 \mathrm{~cm} /$ $1000 \mathrm{yr}$ (upper part) and about $10 \mathrm{~cm} / 1000 \mathrm{yr}$ (lower part).

Normally-graded sequences as indication for turbidites have been reported to be frequent in Subunits $\mathrm{Ia}$ and $\mathrm{Ib}$, less frequent in Subunits Ic and Id, and with a frequency of only few percent in Subunit IIa.

In order to judge this information correctly, one should take into consideration that the recovery was around $100 \%$ in Cores $650 \mathrm{~A}-1 \mathrm{H}$ through $13 \mathrm{H}$ (nearly identical with Subunits Ia and Ib) but decreased to a mean value of $39 \%$ in the deeper cores (in some cases even no recovery). 


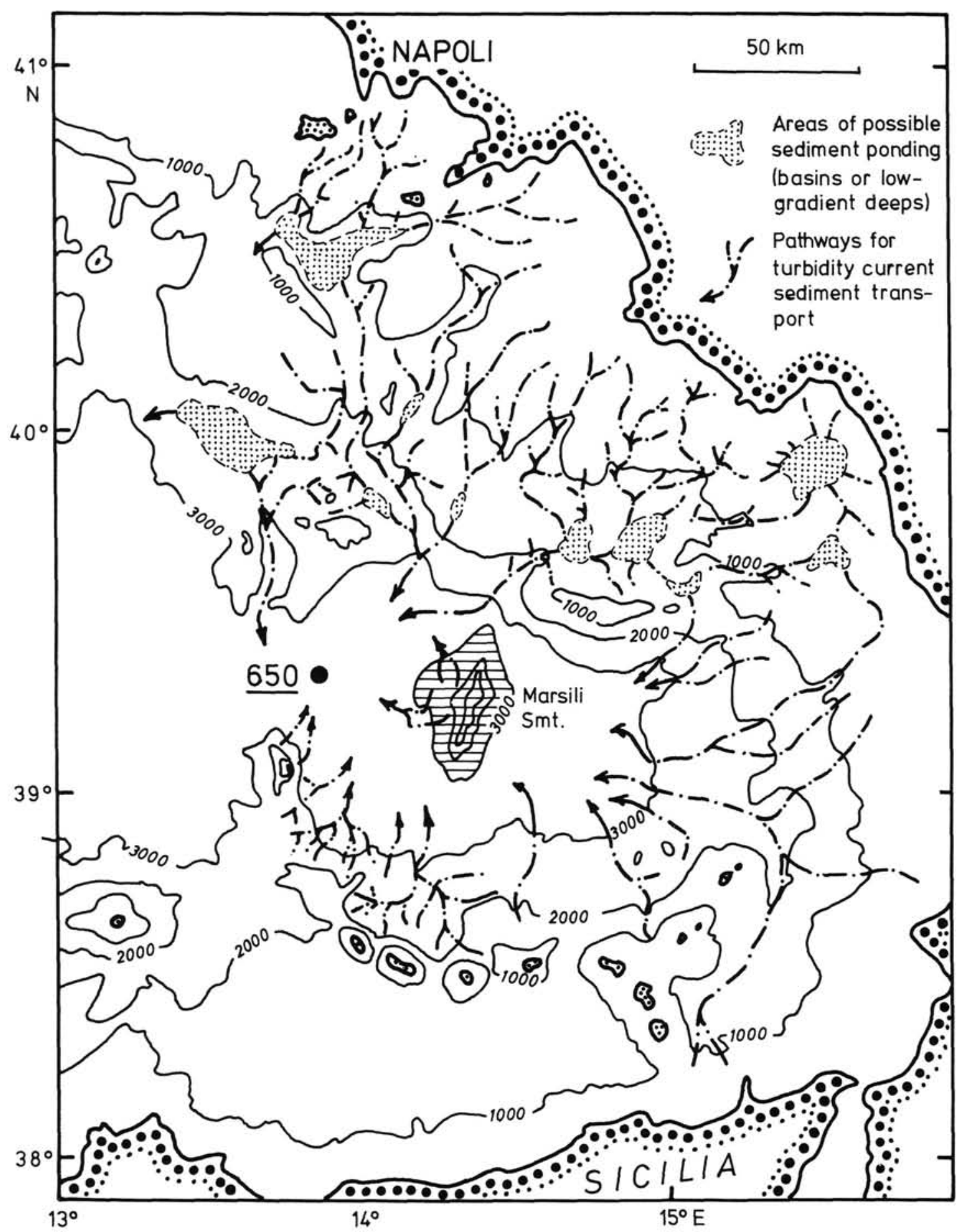

Figure 1. Bathymetric sketch map of the eastern Tyrrhenian Sea showing the morphological situation and possible paths and impediments for downslope sediment transport.

\section{Partial Redescription of Lithology}

It was one of the stratigraphic projects of Leg 107 to establish a tephra chronology for the Tyrrhenian Sea. As already known on board, there are many problems in identifying true ash fall layers and distinguishing them from normally-graded layers with volcanic detritus components. However, there was no time to describe the lithology of Site 650 as detailed as neces- sary for this goal. Therefore, Floyd McCoy and Winton Cornell, Woods Hole Oceanographic Institution, redescribed the cores at the ODP East Coast Repository (L-DGO) with regard to the occurrence of normally-graded layers and/or Bouma sequences as well as readily identifiable tephra layers. They interpreted 235 individual layers which are suspected to be turbidites. Only 53 layers interpreted to be true tephra layers were reported. This information is based on megascopic observations only and 
is, of course, not yet the solution of the set of problems. However, it will be helpful to focus further studies on the most promising lithological levels.

\section{Criteria for Sampling}

The sampled and studied intervals are unevenly scattered over the drilled sediment column. The reasons are two: (1) to identify turbidites or parts of them (in case of incomplete recovery) and (2) to study their provenances and triggering events.

Using observations and a few analyses made on board, we started our study with samples from following intervals (the respective special problems are indicated):

1. Cores $650 \mathrm{~A}-11 \mathrm{H}-2,58 \mathrm{~cm}$, to $650 \mathrm{~A}-14 \mathrm{X}-\mathrm{CC}$ (thick "volcanic sand" and overlying "homogenous calcareous mud").

2. Core 650A-17X-1, 74-121 cm (complete turbidite sequence including burrowed sediment on the top?).

3. Core $650 \mathrm{~A}-20 \mathrm{X}-1,67 \mathrm{~cm}$, to $-20 \mathrm{X}-\mathrm{CC}$ (nature of "homogenous" calcareous mud?).

4. Core $650 \mathrm{~A}-26 \mathrm{X}-1,43 \mathrm{~cm}$, to $650 \mathrm{~A}-26 \mathrm{X}-\mathrm{CC}$ (nature of "homogenous" mud?).

5. Core $650 \mathrm{~A}-27 \mathrm{X}-1,70 \mathrm{~cm}$, to $650 \mathrm{~A}-27 \mathrm{X}-\mathrm{CC}$ (nature of "homogenous" mud?).

6. Core $650 \mathrm{~A}-31 \mathrm{X}-2,70 \mathrm{~cm}$, to $650 \mathrm{~A}-31 \mathrm{X}-\mathrm{CC}$ (nature of "homogenous" indurated mud?).

7. Core $650 \mathrm{~A}-38 \mathrm{X}-1,40-73 \mathrm{~cm}$ (complete turbidite sequence?).

8. Core $650 \mathrm{~A}-56 \mathrm{X}-1$ to $650 \mathrm{~A}-56 \mathrm{X}-\mathrm{CC}$ (nature of "homogenous" tuffaceous calcareous mudstone?).

The second set of samples was requested mainly for studies of individual normally-graded layers with regard to their indicative value for geodynamics.

Finally, some samples, taken for micropaleontological studies (G. Glaçon) outside the sedimentological sampling scheme, have been used for stratigraphic interpretation.

\section{METHODS}

The following laboratory methods have been applied:

1. Grain size analysis: sieving for sand fraction; buret cylinder method according to Fabricius and Müller (1970) for silt and clay fractions.

2. Organic carbon and total carbonate: The samples were dried $\left(40^{\circ} \mathrm{C}\right)$ and ground to a size less than $40 \mu \mathrm{m}$. Carbon has been analyzed volumetrically using a LECO analyzer (two analyses on treated and untreated material respectively). Organic carbon: carbonate solution with $1 \mathrm{~N} \mathrm{HCl}$. Total carbonate: calculation from the difference between total carbon and organic carbon content.

3. Carbonate and bulk mineralogy: X-ray analysis with unoriented powder specimens with scanning speed of $1^{\circ} 2 \theta / \mathrm{min}$. The calcite/dolomite ratio was estimated after the method described by Tennant and Berger (1957). The $\mathrm{MgCO}_{3}$ content of calcite was determined by the shift of the 104 peak of calcite (Goldsmith and Graf 1958). The relative frequency of noncarbonate minerals has been only roughly estimated using their peak heights.

4. Clay mineralogy: The samples were decarbonated in $0.1 \mathrm{~N} \mathrm{HCl}$ and treated for few minutes with $0.5 \mathrm{~N} \mathrm{NaOH}$ at $80^{\circ} \mathrm{C}$ in order to dissolve possible siliceous matrix (Wewer, 1975). The less than $2-\mu \mathrm{m}$ fraction was separated applying the Atterberg method. Oriented slides were made by pipetting the dispersed particles onto glass slides. Following x-ray analyses were carried out between $2^{\circ}$ and $22^{\circ} 2 \theta$ (scanning speed $1^{\circ} 2 \theta / \mathrm{min}$ ): (a) on the untreated oriented aggregates, (b) after ethyleneglycol treatment. A semiquantitative evaluation of the records for smectite, illite, kaolinite, and chlorite has been made using the weighted peak area method described by Biscaye (1965). The frequency values indicate only the relative abundance of the listed minerals.

5. The source of turbidite material was sought on the basis of species compositions of benthic foraminifers. Their depths are estimated on the analogy of the Recent bathymetric distribution of species, mainly in the Mediterranean (e.g., Venec-Peyre, 1983) but also in the North At- lantic (e.g. Phleger et al., 1953), Gulf of Gascogne (e.g., Pujos-Lamy, 1973), and Gulf of Mexico (Pflum and Frerichs, 1976). The numbers indicating the depth zones 1-7 correspond to the bathymetric zonation in the Mediterranean of Wright (1979) as follows: $1=$ inner neritic (0-50 $\mathrm{m}) ; 2$ = outer neritic (50 to $150-200 \mathrm{~m}$ ); 3 = upper epibathyal (150-200 to $500-700 \mathrm{~m}) ; 4=$ lower epibathyal $(500-700$ to $1000-1300 \mathrm{~m}) ; 5=$ upper mesobathyal (1000-1300 to $1800 \mathrm{~m}), 6=$ mid-mesobathyal $(1800$ $2500 \mathrm{~m}) .7=$ lower mesobathyal $(2500-4000 \mathrm{~m})$. Assemblages of benthic foraminifers of some samples are transferred into depth zone histograms showing cumulative numbers of individuals in every depth zone. The present water depth at Site $650(3516 \mathrm{~m})$ belongs to the lower mesobathyal zone.

\section{DETAIL DESCRIPTION OF STUDIED INTERVALS}

\section{Layer 1 (Core 2, Section $5,40 \mathrm{~cm}$, to Section $6,150 \mathrm{~cm}$ )}

This layer (thickness: $2.60 \mathrm{~cm}$; depth below seafloor: 9.40 $12.00 \mathrm{~m}$ ) consists of a macroscopically sandy lower part (base to Section $650 \mathrm{~A}-2 \mathrm{H}-6,17.5 \mathrm{~cm}$ ) and a nearly homogenous to only slightly laminated upper part.

\section{General Textural Data}

Grain size distribution as well as carbonate and organic carbon contents are synoptically presented on Figure 2.

Grain size distribution: The curves show a break between Sections $650 \mathrm{~A}-2 \mathrm{H}-5$ and -6 . Sand size decreases from base $(90 \%)$ to top of Section $650 \mathrm{~A}-2 \mathrm{H}-6(0 \%)$. On the contrary, silt increases from $10 \%$ to $77 \%$. Clay size increases steadily from $0 \%$ to $39 \%$ at the top of Section $650 \mathrm{~A}-2 \mathrm{H}-6$. Thus, grain size distribution indicates a typical normally-graded sequence within Section 650A-2H-6. Within Section 650A-2H-5, there are only two samples. Their wide distances from each other and from top of Section $650 \mathrm{~A}-2 \mathrm{H}-6$ make the interpretation of their textural data somewhat hazardous. The grain size distribution, however, seems to indicate, that the macroscopically nearly homogenous or only slightly laminated part of this layer does not only represent the upper finer-grained part of a normally-graded sequence but contains at least one more separate sedimentary interval of generally silty-clayey texture.

Organic carbon and total carbonate contents: They support the observations from grain size distribution for Section 650A2H-6 interval but do not distinctly support the speculative interpretation for Section 650A-2H-5 interval.

Bulk mineralogy: Quartz, calcite, and feldspar; additionally dolomite.

Clay mineralogy: Illite and irregular mixed layer minerals are always present. Kaolinite and chlorite occur in varying proportions.

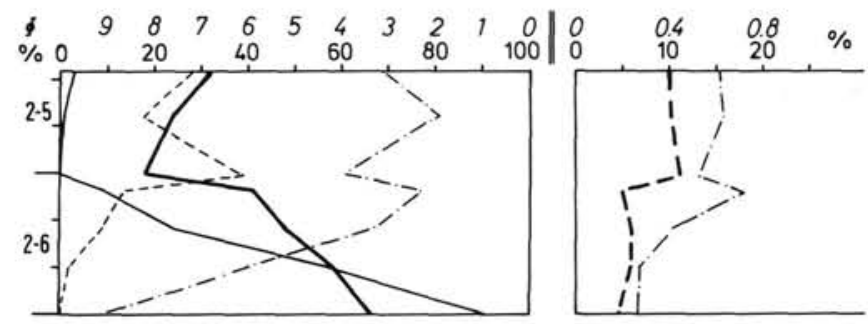

Figure 2. Sedimentological parameters for Core $650 \mathrm{~A}-2 \mathrm{H}$, Section 5,40 $\mathrm{cm}$ to Section $6,150 \mathrm{~cm}$. Grain size distribution (left) as well as organic carbon and total carbonate contents (right) of studied intervals. Note the different vertical scales. Left side diagrams: --.---- (thin) = sand, ........ = silt, ....... = clay, ......- (bold) = mean size (sensu Folk). Right side diagrams: -- -- -- (bold) $=$ total carbonate, -...-.- = organic carbon. 


\section{Biogenic Components}

Planktonic and benthic foraminifers, ostracodes, fragments of bryozoans, echinoid spines, siliceous sponge spicules, and plant remains (wood, fragments of seeds and fruits) all occur. Benthic foraminifers are rare except in the two deepest samples (see Table 1). There, neritic and upper epibathyal elements (zones 1, 2, and 3) are dominant (Fig. 3).

Planktonic foraminifers: The base sample (650A-2H-6, $147-$ $149 \mathrm{~cm}$ ) is characterized by a mixture of Globigerina bulloides, G. quinqueloba, Globorotalia scitula, Globigerinita glutinata, dextral Neogloboquadrina pachyderma (all abundant), dextral $N$. dutertrei, sinistral Globorotalia truncatulinoides excelsa, G. inflata, Globigerinoides ruber (all rare), and the cold-water-indicating pteropod Limacina retroversa. The samples following upcore show very similar assemblages but without Globorotalia inflata and $G$. truncatulinoides excelsa. Sample 650A-2H-6, 2-4 $\mathrm{cm}$, is barren. In the upper part of the studied interval, the spectrum is similar to that of the lower part but without Globorotalia scitula. Sample 650A-2H-5, 92-96 cm, contains only few foraminifers larger than $125 \mu \mathrm{m}$ and until the top sample (650A$2 \mathrm{H}-5,40-42 \mathrm{~cm}$ ), size and number of foraminifers continue to decrease. These observations support the hypothesis that the studied interval contains two separate sedimentary units.

\section{Nonbiogenic Components of Sand Fractions}

The sand fraction is predominantly represented by grain size interval 63-125 $\mu \mathrm{m}$. This interval contains mainly quartz, feldspar, volcanic glass, and mica. Within the coarser grained fractions, mica of different colors is also a main constituent besides clasts of light colored sediments and of low-grade phyllites.

\section{Interpretation}

Section $650 \mathrm{~A}-2 \mathrm{H}-6$ represents a turbidite which perhaps continues into the deepest part of Section $650 \mathrm{~A}-2 \mathrm{H}-5$. The upper part of the studied interval contains at least one more separate turbidite layer of much finer grain size spectrum than the underlying one.

\section{Stratigraphic Hypothesis}

Overlying sediment: Sample 650A-2H-3, 92-96 cm (from a thin turbidite layer), contains an assemblage with abundant Globorotalia inflata, common Globigerinoides ruber, and some dextral Globorotalia truncatulinoides excelsa as well as reworked upper Pliocene species (especially Globorotalia tosaensis). In the Tyrrhenian Sea we have the last occurrence of dextral $G$. truncatulinoides excelsa during Termination I of Broecker and Van Donk, 1970 (G. Glaçon, unpubl. data). Within the Holocene, sinistral individuals are very dominant. $G$. inflata occurs sporadically within the Holocene. In isotope Stage $2 G$. inflata and $G$. truncatulinoides excelsa are almost absent (Muerdter and Kennett, 1983). Below Stage 2 dextral G. truncatulinoides excelsa occur perhaps in Stage 5. Since we found only dextral $G$. truncatulinoides excelsa in Sample 650A-2H-3, $92-96 \mathrm{~cm}$, it is most likely that this sediment is not older than about Termination I (about 10,000 yr).

Underlying sediment: Sample 650A-3H-1, 136-140 cm, contains a cold assemblage with very abundant Globigerina bulloides, Globorotalia scitula (larger than $250 \mu \mathrm{m}$ ), and the cold pteropod Limacina retroversa. This sediment should not be older than Stage 2 (maximum age 27,000 yr).

Result: The stratigraphic position of the studied interval cannot be older than isotope Stage 2 and is most likely within this stage.

\section{Layer 2 (Core 3, Section 3, 17-149 cm)}

This layer consists of a light-colored, somewhat laminated and moderately bioturbated sediment (thickness: $1.32 \mathrm{~m}$; depth below seafloor: $15.87-17.19 \mathrm{~m}$ ) with a darker-colored, few centimeter thick base (which unfortunately is not yet sampled).

\section{General Textural Data}

Grain size distribution, organic carbon, and total carbonate are presented on Figure 4.

Grain size distribution: mean size (sensu Folk) indicates a normal gradation.

Organic carbon and total carbonate: The significance of both curves is impaired by the lack of samples in the deeper part. Organic carbon values vary in a wide scale whereas carbonate contents increase distinctly in the upper part from $11 \%$ to $27 \%$.

Carbonate mineralogy: Calcite is the only identified carbonate mineral. Its $\mathrm{MgCO}_{3}$ content varies between $1.5 \%$ and $2.8 \%$.

Bulk mineralogy: The deepest sample $(650 \mathrm{~A}-3 \mathrm{H}-3,134-136$ $\mathrm{cm}$ ) contains quartz, calcite, and feldspar; mica, kaolinite, and chlorite show low intensities (which in powder analyses indicate considerable amounts of these minerals). In the other samples only quartz, calcite, and feldspar are identified.

Clay mineralogy: Illite and irregular mixed layer minerals are always present; kaolinite dominates chlorite.

\section{Components of Sand Fractions}

Sand sized components are always rare. Planktonic foraminifers and indefinite debris of calcareous shells signalize in the deepest sample $(650 \mathrm{~A}-3 \mathrm{H}-3,134-136 \mathrm{~cm})$ the content of "coarser" material. Volcanic glass shards are a component in all samples. The upper samples $(650 \mathrm{~A}-3 \mathrm{H}-3,63-65 \mathrm{~cm}$, to $650 \mathrm{~A}-3 \mathrm{H}-3,22-$ $24 \mathrm{~cm}$ ) contain fragments of slightly cemented sediment.

Planktonic foraminifers: The samples from the deeper part contain cool assemblages dominated by Globigerina bulloides with few G. quadrilatera, rare G. cariacoensis, and dextral Neogloboquadrina dutertrei (larger than $200 \mu \mathrm{m}$ ) as well as Globigerinita glutinata (larger than $125 \mu \mathrm{m}$ ). Limacina retroversa is abundant. These assemblages suggest isotope stage 2 . The samples from the upper part are getting poorer.

\section{Sedimentological Interpretation}

The occurrence of planktonic foraminifers and the upcoreincrease of carbonate contents point to a gravity sedimentation. Because of incomplete study, this layer is interpreted only reservedly as turbidite.

\section{Stratigraphic Hypothesis}

Overlying sediment: Sample $650 \mathrm{~A}-3 \mathrm{H}-1,136-140 \mathrm{~cm}$, should not be older than isotope stage 2 .

The layer itself: No exact information.

Underlying sediments: Sample $650 \mathrm{~A}-3 \mathrm{H}-4,14-18 \mathrm{~cm}$, contains only cool species. In the grain size fraction between 500 and $200 \mu \mathrm{m}$ only common Globigerina bulloides, in the smaller size fractions abundant G. quinqueloba, common dextral Neogloboquadrina pachyderma and few Globigerinita occur. This assemblage may reflect isotope Stage 2 .

Result: This layer should be situated within isotope Stage 2 .

\section{Layer 3 (Core 3, Section 5, 22-87 cm)}

In this layer (thickness: $0.65 \mathrm{~m}$; depth below seafloor: $18.92-$ $19.57 \mathrm{~m}$ ), the lower $52 \mathrm{~cm}$ are macroscopically sandy, the upper part of the layer is nearly homogenous and slightly laminated at the top.

\section{General Textural Data}

Grain size distribution as well as carbonate content and organic carbon content curves are shown in Figure 5.

The layer represents a normally-graded sequence without clay size content. Total carbonate and organic carbon contents vary at low levels within the sandy interval and increase distinctly within the "homogenous" upper part (one sample only). 
Bulk mineralogy: quartz, calcite $\left(2 \% \mathrm{MgCO}_{3}\right)$, mica, and feldspar.

Clay mineralogy: Illite and irregular mixed layer minerals are always present; kaolinite dominates chlorite.

\section{Biogenic Components}

Few specimens of benthic and planktonic foraminifers, ostracodes, pteropods, echinoid spines, and wood.

In the benthic foraminiferal assemblages (Table 1), inner neritic (zone 1) and epibathyal (zones 3 and 4) elements are abundant (Fig. 3).

Planktonic foraminifers: The samples between $650 \mathrm{~A}-3 \mathrm{H}-5$, $85-87 \mathrm{~cm}$, and $650 \mathrm{~A}-3 \mathrm{H}-5,38-40 \mathrm{~cm}$, contain small numbers of Globorotalia inflata, Globigerinoides ruber, G. cyclostomus (temperate to warm), as well as Globigerina bulloides (cold). Moreover, there are reworked species from early Pliocene (Globorotalia puncticulata in $650 \mathrm{~A}-3 \mathrm{H}-5,57-59 \mathrm{~cm}$; $G$. margaritae in $650 \mathrm{~A}-$ $3 \mathrm{H}-5,38-40 \mathrm{~cm})$ and from upper Miocene $(G$. conoidea in $650 \mathrm{~A}-3 \mathrm{H}-5,38-40 \mathrm{~cm})$. Near the top (650A-3H-5, 23-25 cm) there is an nonnormal distribution of planktonic foraminifers in the grain size fractions. The finest fraction (less than $88 \mu \mathrm{m}$ ) is barren; in the fraction $88-125 \mu \mathrm{m}$, Globigerina quinqueloba occurs rarely, and in the coarser fractions planktonic foraminifers are more frequent: Globigerina bulloides (dominant), Globigerinoides elongatus, and dextral Neogloboquadrina dutertrei (rare).

\section{Nonbiogenic Components of Sand Fractions}

The sand fractions (Pl. 1, Fig. 1 demonstrates an average composition of fraction 125-177 $\mu \mathrm{m}$ ) predominantly consist of quartz (larger grains sometimes rounded); dark volcanic glass of low vesicularity (often with pyrogenic crystals), but also pumice with spheric vesicles; and black and red opaque lapilli of low vesicularity. There occur also fragments of metamorphic rocks (preliminary, R. Sartori and G. Zuffa, pers. comm., 1987): lowgrade phyllites, mostly sericitic; quartz-biotite medium- to highgrade metamorphic rocks; and greenish clasts with possible pyroxene (ophiolite suites?). Moreover, there occur mica, feldspar, greenish to olive colored minerals, and sediment clasts (low lithification).

\section{Sedimentological Interpretation}

The polymict composition and the normal gradation characterize this layer as turbidite.

\section{Stratigraphic Hypothesis}

Overlying sediment: Samples $650 \mathrm{~A}-3 \mathrm{H}-4,70-74 \mathrm{~cm}$, and $650 \mathrm{~A}-3 \mathrm{H}-4,32-36 \mathrm{~cm}$, show about the same assemblages as Sample $650 \mathrm{~A}-3 \mathrm{H}-3,130-134 \mathrm{~cm}$, supposed to be Stage 2 (see "Layer 2").

The layer itself: no exact information.

Underlying sediments: Sample $650 \mathrm{~A}-3 \mathrm{H}-5,135-139 \mathrm{~cm}$, is clearly a mixture of cool species suggesting Stage 2 with warmer species like Globigerinoides elongatus. The occurrence of Limacina retroversa is noted. The assemblage resembles one from Stage 2.

Result: This layer may be situated within isotope Stage 2 .

\section{Layer 4 (Core 5, Section 3, 63-150 cm)}

The upper boundary of the layer (thickness: $0.87 \mathrm{~m}$; depth below seafloor: $36.43-37.30 \mathrm{~m}$ ) is uncertain. Between $650 \mathrm{~A}$ $5 \mathrm{H}-3,53 \mathrm{~cm}$, and $650 \mathrm{~A}-5 \mathrm{H}-3,63 \mathrm{~cm}$ (above the studied layer), darker-colored sediments like those of this studied layer enclose fragments of different sizes of a lighter-colored sediment which seems to be identical with that above level $650 \mathrm{~A}-5 \mathrm{H}-3,53 \mathrm{~cm}$. We take this feature to be a slumping structure rather than a drilling disturbance. The lower boundary seems to be sharp (at $650 \mathrm{~A}-5 \mathrm{H}-4,1 \mathrm{~cm}$ ?) but is influenced by the cut between Sections $650 \mathrm{~A}-5 \mathrm{H}-3$ and -4 .

\section{General Textural Data}

Grain size distribution, contents of organic carbon, and total carbonate are presented on Figure 6. Only three samples are available up to now $(650 \mathrm{~A}-5 \mathrm{H}-3,65-67 \mathrm{~cm}, 650 \mathrm{~A}-5 \mathrm{H}-3,121-$ $123 \mathrm{~cm}$, and $650 \mathrm{~A}-5 \mathrm{H}-3,146-148 \mathrm{~cm}$ ). They show a very simple grain size distribution; the two deepest samples consist of $100 \%$ sand, the upper one is composed of $78 \%$ sand and $22 \%$ silt. Total carbonate content is generally low $(5 \%-7 \%)$ with increasing tendency upcore. Organic carbon content varies between $0.2 \%$ and $0.3 \%$.

\section{Biogenic Components}

They are not very frequent. Beside skeletal fragments of echinoderms and bryozoans and debris of gastropods, there occur few ostracodes as well as benthic and planktonic foraminifers. Benthic foraminifers are frequent only in the base sample (see Table 1) and a mode in the histogram occurs at upper epibathyal (Fig. 3).

The assemblages of planktonic foraminifers are poor. A sinistral Globorotalia truncatulinoides excelsa and few G. inflata, Globigerina bulloides, Globigerinoides elongatus, and Orbulina universa have been found.

\section{Nonbiogenic Components of Sand Fractions}

The dominating constituents of the sand fractions are shards of light-colored and (subordinately) brownish pumice of different vesicularity (elongate to spheric vesicles). There occur also cuspate and platy shards of brownish glass (increasing frequency toward the top) and dark gray and reddish opaque lapilli with low vesicularity. Mineral grains (quartz, feldspar, and greenish and olive colored undetermined minerals) are frequent in the finer fractions of the base sample but become distinctly less frequent toward the top.

\section{Sedimentological Interpretation}

Grain size distribution as well as the content of bryozoans and benthic foraminifers from shallower environments characterize this layer as turbidite. Its complete thickness is unknown.

The original thickness is possibly reduced by slumping. Compared with the other studied layers, it is not very plausible to imagine a turbidity current which only remobilizes coarse-grained material including shallow-water biogenic material. The layer can be easily compared with any small section of the deeper parts of the thick turbidites (see "Layer 6" and "Layer 9") which are characterized by very similar grain size/carbonate content relations (Figs. 8 and 11) and shallow-water biogenic contents.

\section{Stratigraphic Hypothesis}

Overlying sediment: The planktonic foraminiferal assemblages from $650 \mathrm{~A}-4 \mathrm{H}-5$ to $650 \mathrm{~A}-5 \mathrm{H}-4,1 \mathrm{~cm}$, seem to be reworked from Stage 3, since Globorotalia inflata is always present. At the state of the study we do not know at which level Stage 3 is in situ. In Sample $650 \mathrm{~A}-5 \mathrm{H}-4,16-18 \mathrm{~cm}$, Limacina retroversa is the only constituent of the fraction larger than $500 \mu \mathrm{m}$. The fractions between 500 and $125 \mu \mathrm{m}$ consist completely of planktonic foraminifers. The assemblage reflects that of Stage 2 with dominant Globigerina bulloides, but Globorotalia inflata is present as usual in Stage 3 (Muerdter and Kennett, 1983).

The layer itself and underlying sediment: no useful information.

Result: The stratigraphic position is uncertain (Stages 2 or 3). 
Table 1. Distribution of benthic foraminifers with indication of water depth significance.

\begin{tabular}{|c|c|c|c|c|c|c|}
\hline No. & & Taxa & & Depth zones & & 1 \\
\hline$\frac{1}{2}$ & $\begin{array}{l}\text { Adelosina spp. } \\
\text { Ammonia spp. }\end{array}$ & & & 1 & $107-650 \mathrm{Acm}$ & \\
\hline 3 & Amphicoryna sca & laris (Batsch) & & $2-3$ & $2 \mathrm{H}-5,89-91$ & \\
\hline 4 & Articulina tubulo & sa (Seguenza) & & $?$ & (1) & \\
\hline $\begin{array}{l}5 \\
6\end{array}$ & $\begin{array}{l}\text { Asterigerinita ma } \\
\text { Astrononion stell. }\end{array}$ & $\begin{array}{l}\text { milla (Williams } \\
\text { igerum (d'Orbi }\end{array}$ & $\begin{array}{l}\text { on) } \\
\text { gny) }\end{array}$ & $\frac{1}{2}$ & $2 \mathrm{H}-6,100-102$ & \\
\hline 7 & Bolivine albatros & si Cushman & & 4 & $2 \mathrm{H}-6,147-149$ & \\
\hline 8 & B. dilatate Reuss & & & $2-4$ & & \\
\hline $\begin{array}{r}9 \\
10\end{array}$ & $\begin{array}{l}\text { Brizalina aenarier } \\
\text { B. alato (Seguenz }\end{array}$ & nsis Costa & & $\begin{array}{l}2 \\
3\end{array}$ & $3 \mathrm{H}-5,38-40$ & \\
\hline 11 & B. catenata (Segu & enza) & & $2-3$ & $3 \mathrm{H}-5.57-59$ & \\
\hline 12 & B. difformis (Wil & liamson) & & $2-3$ & 3H-5, $57-59$ & \\
\hline $\begin{array}{l}13 \\
14\end{array}$ & $\begin{array}{l}\text { Buccella granulos } \\
\text { Buliming ocanthi }\end{array}$ & $\begin{array}{l}a \text { (di Napoli A } \\
a \text { Costa }\end{array}$ & lliata) & $\frac{1}{3}$ & $3 \mathrm{H}-5,85-87$ & \\
\hline is & B. aculeata d'Orb & igny & & $2-6$ & & 1 \\
\hline 16 & B. gibbo William & & & $2-3$ & $5 H-3,121-121$ & \\
\hline 17 & & & & $2-5$ & & \\
\hline 18 & B. marginata d'O & rbigny & & $2-4$ & $5 \mathrm{H}-3,146-148$ & \\
\hline 19 & Cassidulina carin & ate Silvestri & & $2-3$ & & \\
\hline $\begin{array}{l}20 \\
21\end{array}$ & $\begin{array}{l}\text { C. spp. } \\
\text { Cassidulinoides b }\end{array}$ & & & $\frac{1}{2}$ & $7 \mathrm{H}-1,20-22$ & \\
\hline 22 & Chilostomella oo & lina Schwager & & 4 & & \\
\hline 23 & Cibicides lobatuh & us (Walker and & Jacob) & 1 & $7 \mathrm{H}-2,20-22$ & \\
\hline 24 & $\begin{array}{l}\text { C. refulgens Mon } \\
\text { C. wuellerstorfi i }\end{array}$ & $\begin{array}{l}\text { tfort } \\
\text { Schwager) }\end{array}$ & & $\begin{array}{l}2 \\
4\end{array}$ & $7 \mathrm{H}-3,20-22$ & \\
\hline $\begin{array}{l}25 \\
26\end{array}$ & cibicidotdes kulle & $\begin{array}{l}\text { Schwaget) } \\
\text { enbergi (Parker }\end{array}$ & & $\begin{array}{l}4 \\
6\end{array}$ & & \\
\hline 27 & C. pachyderma (C & Czjzek) & & $3-5$ & $7 \mathrm{H}, \mathrm{CC}(15-17)$ & \\
\hline 28 & Eggerella bradyi & Cushman & & 4 & & \\
\hline 29 & Eponides sp. & & & 2 & $7 \mathrm{H}, \mathrm{CC}(36-38)$ & 2 \\
\hline $\begin{array}{l}30 \\
31\end{array}$ & $\begin{array}{l}\text { Elphidium spp. } \\
\text { Gavelinopsis proe }\end{array}$ & geri (Heron-Al & (en and Earland) & ${ }_{2-4}^{1}$ & $8 \mathrm{H}-4,145-147$ & \\
\hline 32 & Glabratella spp. & & & $i$ & & \\
\hline 33 & Globobulimina sf & D. & & 3 & $9 \mathrm{H}-3,28-30$ & \\
\hline 34 & Globocassidulina & subglobosa (B) & rady) & $3-4$ & & \\
\hline $\begin{array}{l}35 \\
36\end{array}$ & $\begin{array}{l}\text { G. spp. } \\
\text { Guttulina spp. }\end{array}$ & & & $\begin{array}{l}2-4 \\
2-4\end{array}$ & $9 \mathrm{H}-3,65-67$ & \\
\hline 37 & Gyroidina spp. & & & $4-6$ & & \\
\hline 38 & $\begin{array}{l}\text { Gyroidinoides spr } \\
\text { Hanzawaia rhodi }\end{array}$ & D. & & $4-6$ & $11 \mathrm{H}-3,116-120$ & \\
\hline 39 & & ensis (Terquem. & & $2-3$ & & \\
\hline 40 & $\begin{array}{l}\text { H. sp. } \\
\text { Hoeglundina eles }\end{array}$ & & & $1-2$ & $11 \mathrm{H}-6,116-120$ & \\
\hline 41 & $\begin{array}{l}\text { Hoeglundina eles } \\
\text { Hyalined bolthica }\end{array}$ & ans (d'Orbigny & & $2-4$ & & \\
\hline 42 & $\begin{array}{l}\text { Hyalined balthice } \\
\text { Lenticuling spp. }\end{array}$ & (Schroter) & & $2-3$ & $12 \mathrm{H}-2,35-37$ & \\
\hline 43 & $\begin{array}{l}\text { Lenticulina spp. } \\
\text { Martinottiella spt }\end{array}$ & & & $2-4$ & & \\
\hline 44 & $\begin{array}{l}\text { Martinoultiella spr } \\
\text { Massilina spp. }\end{array}$ & & & 3 & $12 \mathrm{H}-2,105-107$ & \\
\hline 45 & Massilina spp. & & & 1 & & \\
\hline 46 & Melonis spp. & & & 2-5 & $12 \mathrm{H}-3,35-37$ & \\
\hline 47 & Miliolinella spp. & & & 1 & & \\
\hline 48 & Neoconarbina or & bicularis (Terqu & em) & 1 & $12 \mathrm{H}-4,35-37$ & 1 \\
\hline 49 & Nonion spp. & & & 1 & & \\
\hline 50 & Planorbulina med & Aiternanensis $\mathrm{d}^{\prime}$ & Orbigny & i & $12 \mathrm{H}-4,105-107$ & \\
\hline 51 & Planuline arimine & ensis d'Orbigny & & $2-4$ & & \\
\hline 52 & Protelphidium sp & & & $i$ & $12 \mathrm{H}-5,35-37$ & \\
\hline 53 & Pullenia spp. & & & $2-4$ & & \\
\hline 54 & Pyrgo spp. & & & 5 & $12 \mathrm{H}-5,105-107$ & 1 \\
\hline s5 & Pyrgoella sphaera & d'Orbigny & & $2-4$ & 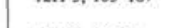 & \\
\hline 56 & Quinqueloculina & bicaringta d'Or & bigny & $1-2$ & $12 \mathrm{H}-6,35-37$ & \\
\hline 57 & Q. oblonga (Mon & tagu) & & $1-2$ & & \\
\hline 58 & Q, padana Percor & & & $1-2$ & $12 \mathrm{H}-6,105-107$ & \\
\hline 59 & $Q$. venusta Karre & & & $2-4$ & & \\
\hline 60 & Q. viennensis Le & Calvez and Le & Calvez & $2-3$ & $13 \mathrm{H}-1,52-54$ & \\
\hline 61 & Q. spp. & & & 1 & & \\
\hline 62 & Rectobolivina zitt & eli (Karret). & & 3 & $13 \mathrm{H}-1,100-102$ & \\
\hline 63 & Reussella sp. & & & 1 & & \\
\hline 64 & Robertinoides bro & dyf Cushman : & and Parker & $4-5$ & $13 \mathrm{H}-1,116-120$ & 1 \\
\hline 65 & Rosalina spp. & & & 1 & & \\
\hline 66 & Sigmoilinita tenu & $s$ (Czjzek) & & 3-5 & $13 \mathrm{H}-2,52-54$ & \\
\hline 67 & Sigmoilopsis scht & umbergeri (Silv & estri) & 3-5 & Wher & \\
\hline 68 & Siphonina spp. & & & $2-4$ & $13 \mathrm{H}-2,100-102$ & 1 \\
\hline 69 & Sorites sp. & & & 1 & & \\
\hline 70 & Sphaeroidina bull & oides d'Orbign & & $2-4$ & $13 \mathrm{H}-2,116-120$ & \\
\hline 71 & Spiroloculine can & aliculata d'Orb & & $2-4$ & & \\
\hline 72 & $S$, spp. & & & 1 & $13 \mathrm{H}-3,52-54$ & \\
\hline 73 & Spiroplectammin & wrighti (Silves & & $2-3$ & & \\
\hline 74 & Textularia pseudo & rugosa Lacroix & & 2 & $13 \mathrm{H} \cdot 3,100-102$ & \\
\hline 75 & Trifarina spp. & & & 3 & & \\
\hline 76 & Triloculina tricar & nata d'Orbigny & & 2 & $13 \mathrm{H}-3,116-120$ & \\
\hline 77 & $T$. spp. & & & 1 & & \\
\hline 78 & Uvigerina auberic & na d'Orbigny & & 3 & $13 \mathrm{H}-4,52-54$ & \\
\hline 79 & U. mediterranea 1 & Hofker & & $3-4$ & & \\
\hline 80 & $U$. peregrina Cus! & $\operatorname{man}$ & & 3-4 & $13 \mathrm{H}-4,100-102$ & \\
\hline 81 & Valvulineria brad & vane (Fornasini & & $2-3$ & & \\
\hline 82 & Miscellanea & & & & $13 \mathrm{H}-4,116-120$ & \\
\hline & & & & & $13 \mathrm{H}-5,52-54$ & \\
\hline & & & & & $13 \mathrm{H}-100-100$ & \\
\hline $\mathrm{TL}$ & Total (upper: 1 & inbroken specin & nens: lower: total s & pecimens). & & \\
\hline RW & Number of rey & vorked specime & ns (shown with - i & t table). & $13 \mathrm{H}-5,116-120$ & \\
\hline $\mathrm{AV}$ & Estimated pale & odepth zones & calculated by simp & e weighted average of & & \\
\hline SHAI & $\begin{array}{l}\text { depth rang } \\
\text { L Ratio of shallo }\end{array}$ & $\begin{array}{l}\text { es of selected s } \\
\text { w water species }\end{array}$ & $\begin{array}{l}\text { Decies). } \\
\text { to total (both unbr }\end{array}$ & oken and broken spec- & $13 \mathrm{H}-6,100-102$ & \\
\hline & $\begin{array}{l}\text { imens). } \\
\text { Ratio of broke }\end{array}$ & secimens & . & 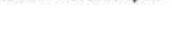 & $14 X, C C(12-14)$ & \\
\hline BR & Ratio of broke & n specimens to & total individuals. & & & \\
\hline & & & & & $17 X-1,119-121$ & \\
\hline & & & & & $20 \times-1,116-118$ & \\
\hline & Depth zones & $\begin{array}{l}\text { Upper limir } \\
\text { (m) }\end{array}$ & $\begin{array}{l}\text { Lower limit } \\
\text { (m) }\end{array}$ & & $20 \mathrm{X}-1,124-126$ & \\
\hline 1 In & iner neritic & 0 & 50 & & $31 X-2,74-76$ & \\
\hline${ }_{2}^{2} \mathrm{O}$ & $\begin{array}{l}\text { uter neritic } \\
\text { pper epibathyal }\end{array}$ & $\begin{array}{c}50 \\
150-200\end{array}$ & $\begin{array}{l}150-200 \\
500-700\end{array}$ & & $38 \times-1,69-71$ & \\
\hline $4 \mathrm{Lg}$ & $\begin{array}{l}\text { pper epibathyal } \\
\text { ower epibathyal }\end{array}$ & $500-700$ & $1000-1300$ & & & \\
\hline $5 U_{t}$ & pper mesobathyal & $1000-1300$ & 1800 & & $38 X-1,71-73$ & \\
\hline $6 \mathrm{M}$ & id mesobathyal & 1800 & 2500 & & & \\
\hline $\begin{array}{l}7 \mathrm{Lo} \\
\text { (Wris }\end{array}$ & $\begin{array}{l}\text { ower mesobathyal } \\
\text { he. 1979) }\end{array}$ & 2500 & 4000 & & $38 \times-1,73-75$ & \\
\hline
\end{tabular}


Table 1 (continued).

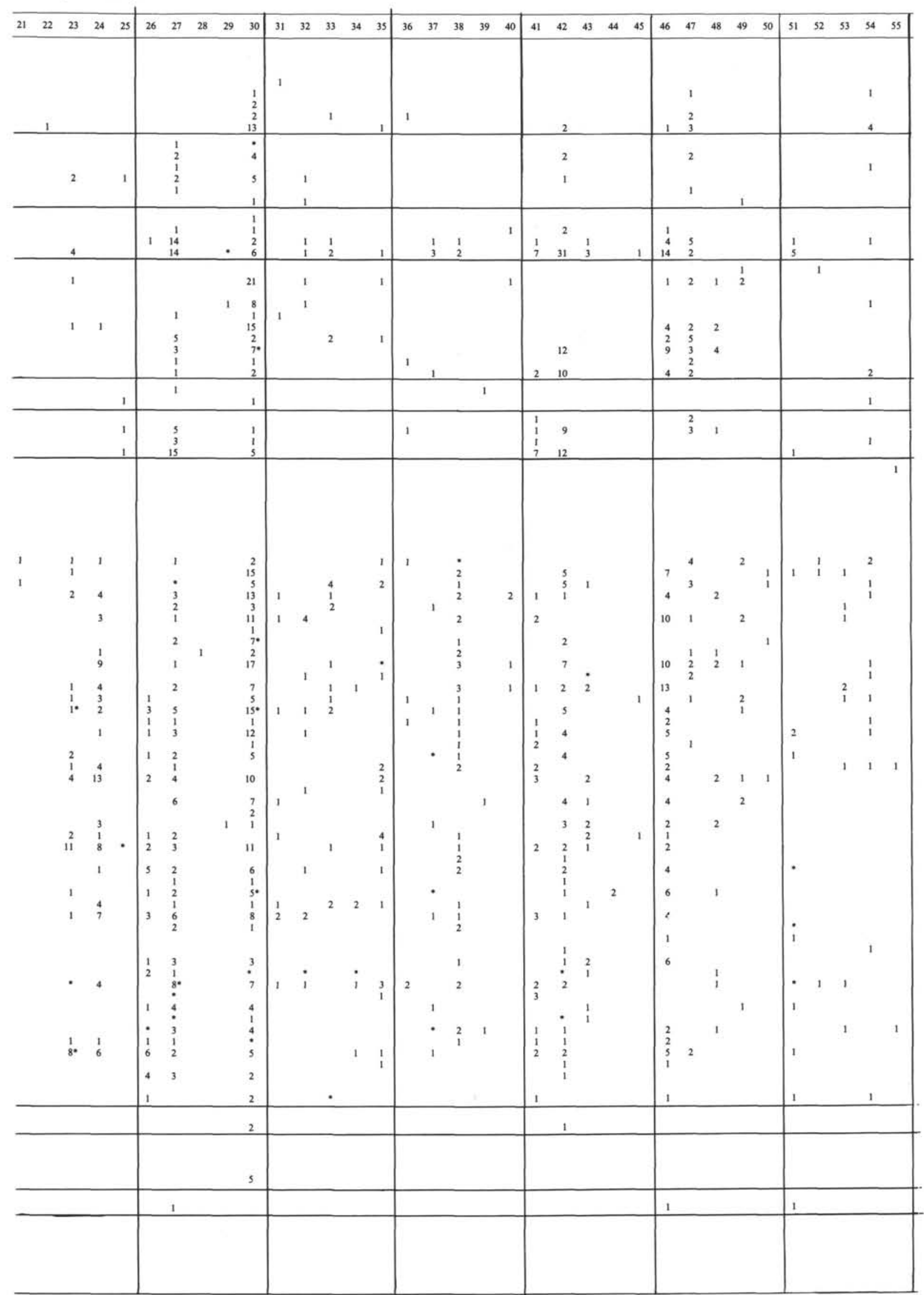


Table 1 (continued).

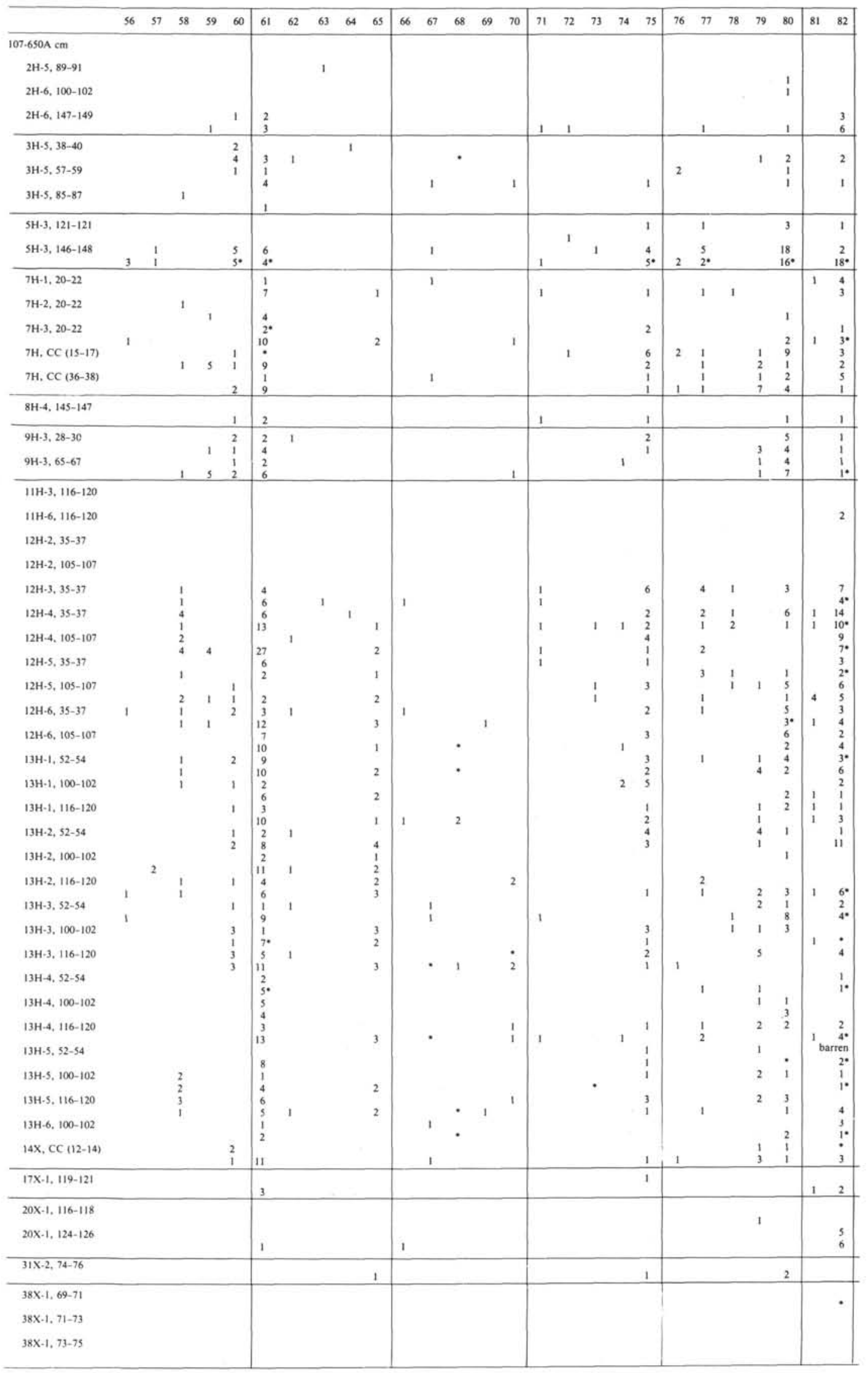


Table 1 (continued).

\begin{tabular}{|c|c|c|}
\hline TL & 1 & II \\
\hline 1 & 1 & 0 \\
\hline 2 & 0 & 1 \\
\hline 5 & 2 & 0 \\
\hline 5 & 2 & 3 \\
\hline $\begin{array}{l}23 \\
46\end{array}$ & $\begin{array}{r}6 \\
21 \\
\end{array}$ & $\begin{array}{l}11 \\
13 \\
\end{array}$ \\
\hline 4 & 0 & 2 \\
\hline 23 & 9 & 6 \\
\hline 8 & 1 & 4 \\
\hline 24 & 13 & 3 \\
\hline 3 & 2 & 1 \\
\hline 8 & 5 & 3 \\
\hline 8 & 2 & 1 \\
\hline ?7. & $3^{3}$ & 4 \\
\hline 121 & 24 & 42 \\
\hline 152 & 35 & 101 \\
\hline 18 & 4 & 4 \\
\hline 57 & 39 & 11 \\
\hline 2 & 1 & 1 \\
\hline 24 & 13 & 6 \\
\hline $\begin{array}{l}20 \\
89\end{array}$ & $\begin{array}{l}3 \\
36\end{array}$ & $\begin{array}{r}4 \\
33\end{array}$ \\
\hline 64 & 11 & 14 \\
\hline 87 & 28 & 41 \\
\hline 23 & 5 & 6 \\
\hline 61 & 18 & 24 \\
\hline 4 & 0 & 3 \\
\hline 11 & 3 & 3 \\
\hline 16 & 4 & 3 \\
\hline 43 & 9 & 19 \\
\hline 22 & 3 & 7 \\
\hline 71 & 14 & 32 \\
\hline 1 & 0 & 1 \\
\hline 0 & 0 & 0 \\
\hline 2 & 0 & 0 \\
\hline 1 & $\begin{array}{l}0 \\
0\end{array}$ & $\begin{array}{l}0 \\
0\end{array}$ \\
\hline 1 & $\begin{array}{l}0 \\
0\end{array}$ & $\begin{array}{l}0 \\
0\end{array}$ \\
\hline 0 & 0 & 0 \\
\hline 1 & 1 & 0 \\
\hline 74 & 20 & 29 \\
\hline 65 & 27 & 2 \\
\hline 89 & 22 & 27 \\
\hline $\begin{array}{l}96 \\
45\end{array}$ & $\begin{array}{r}36 \\
5\end{array}$ & $\begin{array}{l}32 \\
13\end{array}$ \\
\hline 98 & 54 & 34 \\
\hline 18 & , & 7 \\
\hline 29 & 17 & 4 \\
\hline 51 & 5 & 20 \\
\hline 92 & 33 & $4 !$ \\
\hline 48 & 9 & 21 \\
\hline 81 & 29 & 38 \\
\hline $\begin{array}{l}54 \\
84\end{array}$ & $\begin{array}{l}19 \\
37\end{array}$ & $\begin{array}{l}14 \\
19\end{array}$ \\
\hline $\begin{array}{l}64 \\
49\end{array}$ & 12 & 2 \\
\hline 69 & 26 & 22 \\
\hline 23 & 6 & 5 \\
\hline 38 & 16 & 13 \\
\hline 32 & 5 & 17 \\
\hline 84 & 32 & 38 \\
\hline 25 & 3 & 7 \\
\hline 69 & 26 & 21 \\
\hline 8 & 6 & 19 \\
\hline 37 & $\begin{array}{l}18 \\
12\end{array}$ & 19 \\
\hline $\begin{array}{l}34 \\
94\end{array}$ & $\begin{array}{l}12 \\
42\end{array}$ & 31 \\
\hline is & 1 & 4 \\
\hline 71 & 20 & 24 \\
\hline 22 & 5 & 7 \\
\hline 37 & 16 & 11 \\
\hline 3 & 7 & 12 \\
\hline 79 & 33 & 31 \\
\hline 10 & 3 & 1 \\
\hline 12 & 6 & 2 \\
\hline 1 & 6 & 4 \\
\hline $2 \theta$ & 8 & 9 \\
\hline 2 & 5 & ${ }^{6}$ \\
\hline & 33 & 20 \\
\hline 13 & $\begin{array}{r}0 \\
15\end{array}$ & $\begin{array}{l}9 \\
4\end{array}$ \\
\hline 30 & $\begin{array}{r}15 \\
4\end{array}$ & 4 \\
\hline 3. & 15 & 12 \\
\hline 3 & 1 & 14 \\
\hline 65 & 25 & 23 \\
\hline 12 & 1 & 6 \\
\hline 18 & 4 & 3 \\
\hline 5 & 0 & 2 \\
\hline 31 & 14 & 6 \\
\hline 3 & 0 & I \\
\hline 18 & 5 & 5 \\
\hline 0 & 0 & \\
\hline 1 & & 0 \\
\hline 5 & 0 & 0 \\
\hline 28 & 6 & 2 \\
\hline 0 & 0 & 0 \\
\hline 14 & 1 & 9 \\
\hline 0 & 0 & 0 \\
\hline 2 & 0 & \\
\hline & 0 & 0 \\
\hline 2 & 0 & 0 \\
\hline 0 & $\begin{array}{l}0 \\
0\end{array}$ & $\begin{array}{l}0 \\
0 \\
0\end{array}$ \\
\hline & & \\
\hline
\end{tabular}

\section{Layer 5 (Core 5, Section 4, 56-94 cm)}

This layer (thickness: $0.38 \mathrm{~m}$; depth below seafloor: $37.86-$ $38.24 \mathrm{~cm}$ ) is macroscopically nearly homogenous except a $2-\mathrm{cm}$ thick finely laminated interval at the base (which unfortunately is not yet sampled).

\section{General Textural Data}

Grain size distribution, contents of organic carbon, and total carbonate are presented on Figure 7.

Grain size distribution: indicates normal gradation (sand and silt decrease from $3 \%$ to $1 \%$ and $67 \%$ to $55 \%$ respectively, clay increases from $30 \%$ to $44 \%$ ). Organic carbon content is low at the base $(0.36 \%)$ and increases upward $(0.62 \%-0.75 \%)$ Total carbonate content increases from $15 \%$ (base) to $18 \%$ (top).

Bulk mineralogy: quartz, calcite, feldspar (the latter especially clearly recorded in deepest sample), and mica.

Clay mineralogy: Illite and irregular mixed layer minerals are always present; kaolinite dominates chlorite.

\section{Components of Sand Fraction}

The very dominant components of the sand fractions are sediment fragments the origin of which cannot be clearly identified (true reworked clasts or incompletely prepared parts of the slightly cemented sediment). In the base sample (directly above the underlying laminated layer), there occur some flat cakes of pyritized fine-grained sandstones containing volcanic glass shards, different mineral grains, and planktonic foraminifers. Perhaps they can be explained as very thin continuations of the underlying laminae. There are also some isolated glass shards.

The biogenic content of the sand fractions is low: planktonic foraminifers (mainly less than $180 \mu$ m diameter), debris of pteropod shells, and at the base very rare siliceous sponge spicules.

Planktonic foraminifers: Near the base there occur only few Globigerina quinqueloba and some undetermined juvenile individuals in the finest fraction. Coarser fractions are barren. In the upper part few Neogloboquadrina dutertrei (larger than 250 $\mu \mathrm{m})$ and rare Globigerina quinqueloba in finer fractions occur.

\section{Sedimentological Interpretation}

Normal gradation, upcore-increasing carbonate content and occurrence of planktonic foraminifers characterize this layer as turbidite.

\section{Stratigraphical Hypothesis}

Overlying sediment: no information from the directly overlying deposits.

The layer itself: no useful information.

Underlying sediment: Sample $650 \mathrm{~A}-5 \mathrm{H}-4,98-100 \mathrm{~cm}$, contains only rare Globigerina bulloides and G. quinqueloba.

Result: The stratigraphic position cannot be established.

Layer 6 (Core 5, Section 6, $0 \mathrm{~cm}$, to Core 7, CC)

The layer (thickness (recovered): $16.88 \mathrm{~m}$; thickness (penetrated): $21.50 \mathrm{~m}$; depth below seafloor: $40.30-61.80 \mathrm{~m}$ ) is not completely recovered. We have to expect that the interval of no recovery (within Core $650 \mathrm{~A}-7 \mathrm{H}$ ) consists of noncohesive sand, since the recovered sandy sediments of Core $650 \mathrm{~A}-7 \mathrm{H}$ are soupy and seem to be easily removable by drilling.

\section{General Textural Data}

Curves of grain size distribution, total carbonate, and organic carbon contents are compiled on Figure 8.

Grain size distribution: The basal part of the layer (whole Core $650 \mathrm{~A}-7 \mathrm{H}$ ) is a sand with $10 \%$ maximum silt content. Within Core $650 \mathrm{~A}-6 \mathrm{H}-\mathrm{CC}$ through Section 5, sand content decreases to $1 \%$ in favor of silt and few percent of clay. In the following up- 

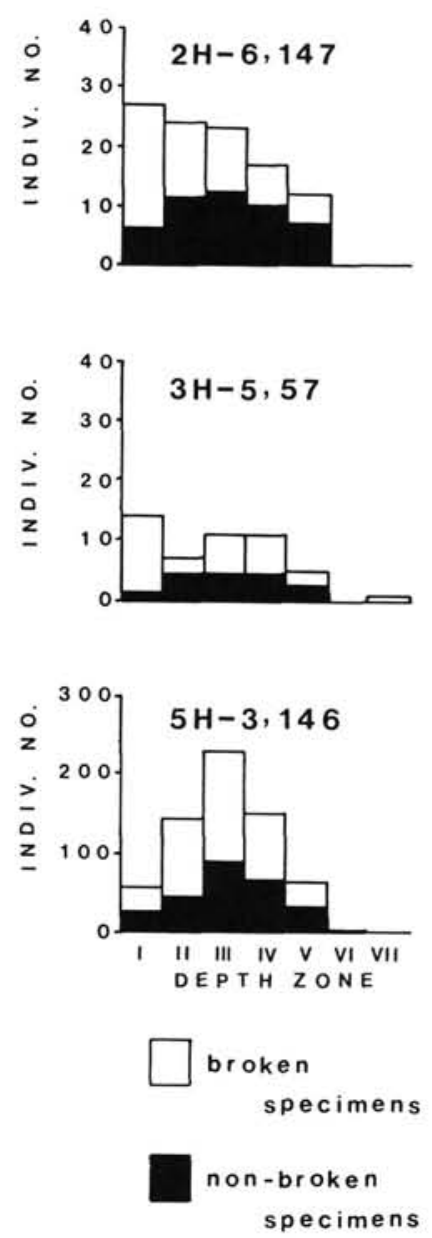
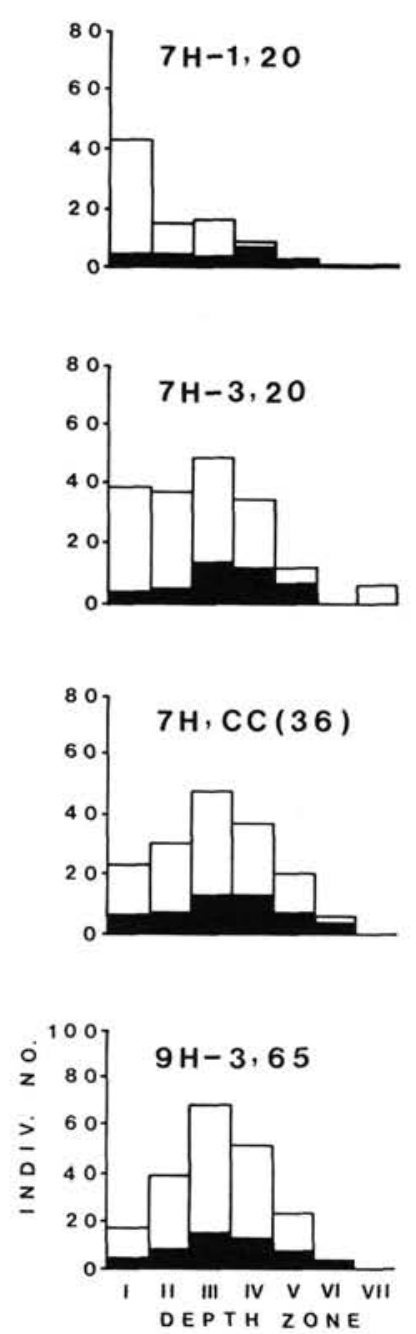
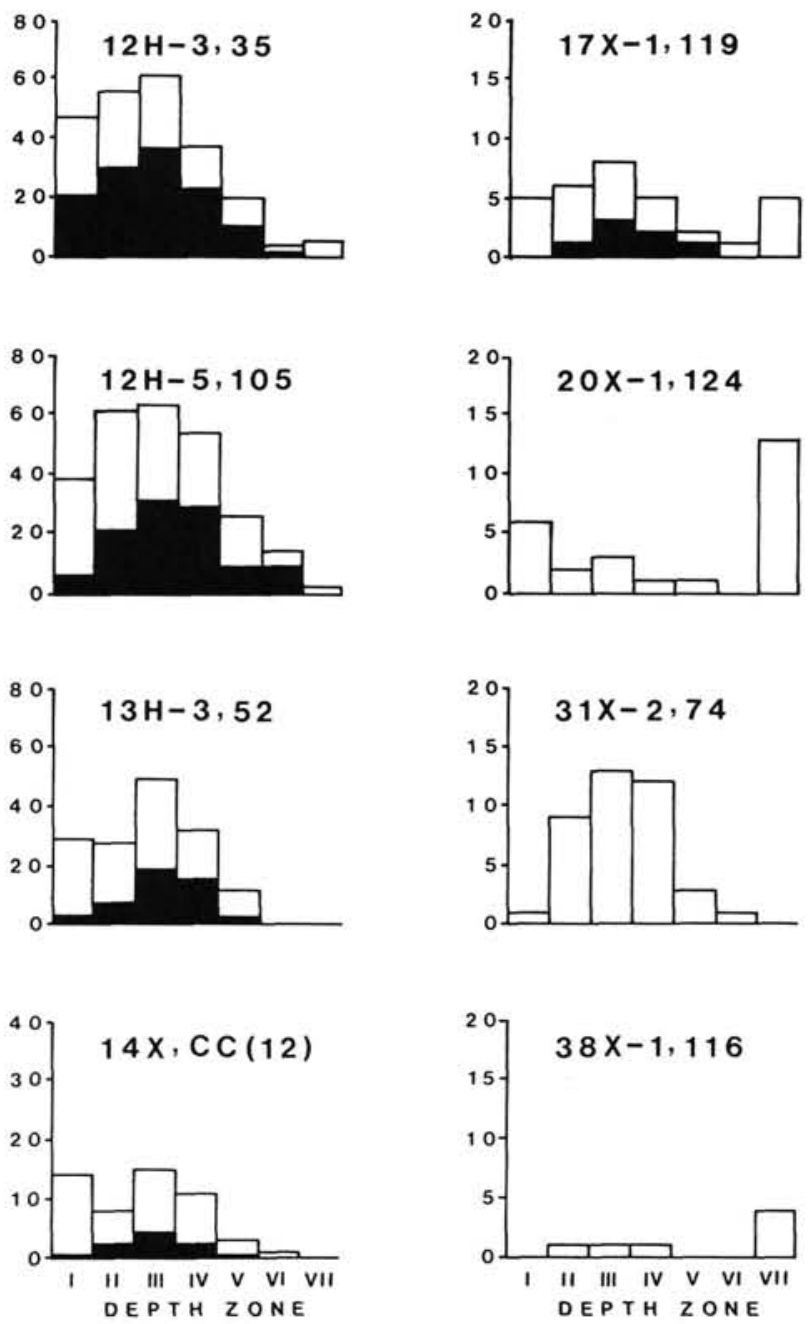

Figure 3. Histograms of frequency of benthic foraminifers according to their bathymetric significance. See Table 1 for explanation of zone numbers.

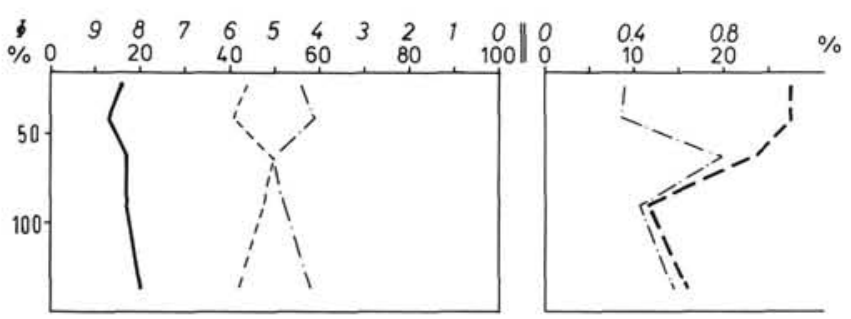

Figure 4. Sedimentological parameters for Core 650A-3H, Section 3, $17-149 \mathrm{~cm}$. See Figure 2 for legend.

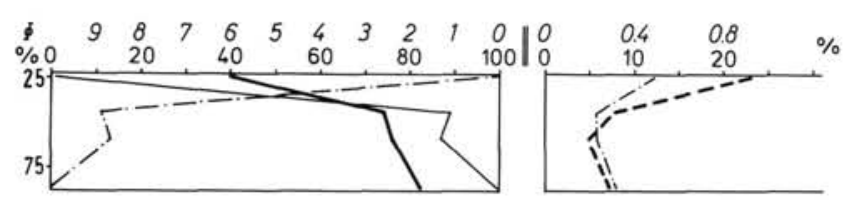

Figure 5. Sedimentological parameters for Core $650 \mathrm{~A}-3 \mathrm{H}$, Section 5 , $22-87 \mathrm{~cm}$. See Figure 2 for legend.

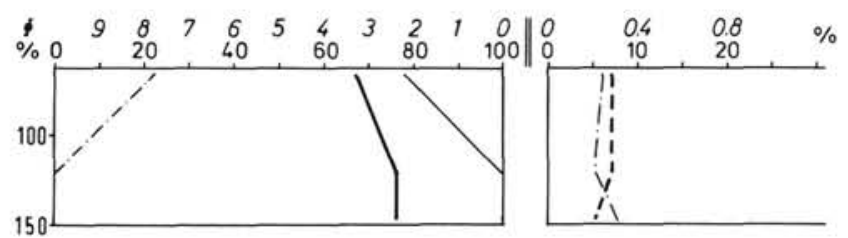

Figure 6. Sedimentological parameters for Core $650 \mathrm{~A}-5 \mathrm{H}$, Section 3, $63-150 \mathrm{~cm}$. See Figure 2 for legend.

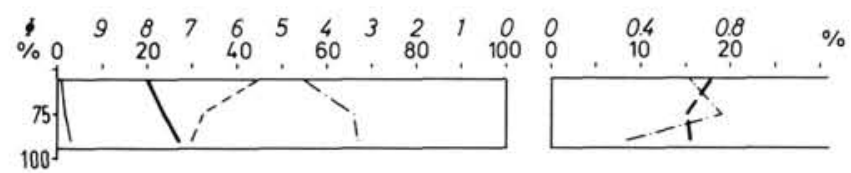

Figure 7. Sedimentological parameters for Core $650 \mathrm{~A}-5 \mathrm{H}$, Section 4, $56-94 \mathrm{~cm}$. See Figure 2 for legend. 


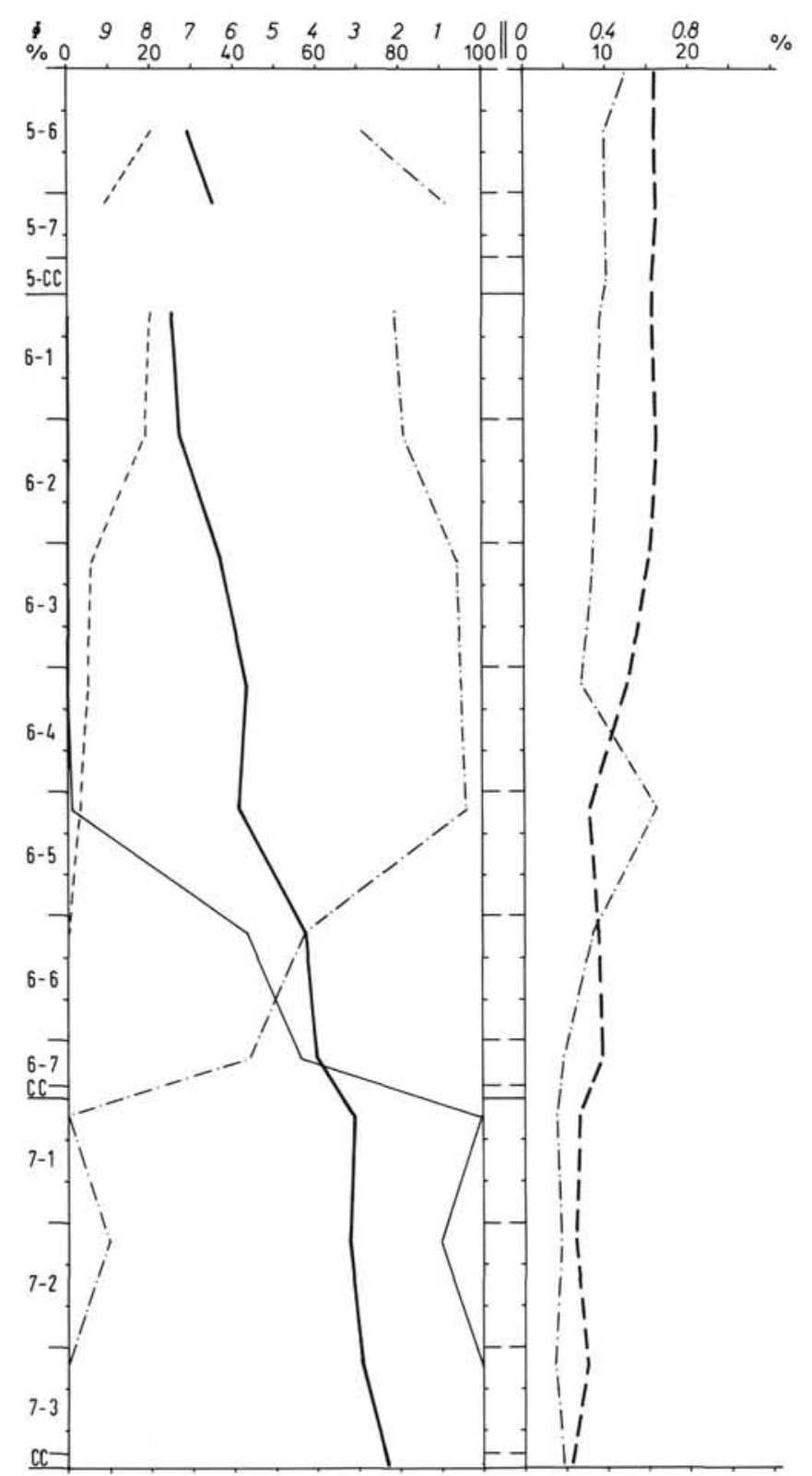

Figure 8. Sedimentological parameters for Core $650 \mathrm{~A}-5 \mathrm{H}$, Section 6,0 $\mathrm{cm}$, to Core $650 \mathrm{~A}-7 \mathrm{H}-\mathrm{CC}$. See Figure 2 for legend.

per part, silt and clay oscillate with the general tendency of the size to decrease upcore.

Organic carbon: content increases generally from about $0.2 \%$ (base) to $0.5 \%$ (top) with an extraordinary maximum of $0.65 \%$ at the top of Section $650 \mathrm{~A}-6 \mathrm{H}-5$.

Total carbonate: content generally increases from $6 \%$ (base) to $16 \%$ (top), showing distinct relations to the grain size (less than $10 \%$ in the sandy interval and more than $10 \%$ in the silty interval).

Bulk mineralogy: quartz, calcite, feldspar, and sometimes dolomite.

Clay mineralogy: Illite and irregular mixed layer minerals are always present; kaolinite dominates chlorite.

\section{Composition of the Sand Fractions}

The sand fractions are highly dominated by light-colored pumice shards with predominantly elongate vesicles (sometimes with pyrogenic crystals). There also occur platy and cuspate glass shards and brownish high-vesicular pumice shards. Plate 1, Figure 2 represents an average composition of fraction 125-177 $\mu \mathrm{m}$.

The biogenic content of the sand fraction (generally not frequent) includes: ostracodes, pteropods, bryozoans, siliceous sponge spicules, echinoid spines, wood, and benthic and planktonic foraminifers.

Benthic foraminifers: Their spectrum is dominated by shallow water species (see Table 1). The modes of histograms move gradually from upper epibathyal (in the lower part) to inner neritic (in the upper part of the studied layer; see Fig. 3).

Planktonic foraminifers: In the base sample $(650 \mathrm{~A}-7 \mathrm{H}-\mathrm{CC}$, $20-22 \mathrm{~cm}$ ) occur in good preservation: Globorotalia inflata (abundant), Orbulina universa (common), Globigerina bulloides, Globigerinoides elongatus, Neogloboquadrina dutertrei (rare), and sinistral Globorotalia truncatulinoides excelsa (very rare). Sample $650 \mathrm{~A}-7 \mathrm{H}-\mathrm{CC}, 15-17 \mathrm{~cm}$, and almost all samples (23) between $650 \mathrm{~A}-7 \mathrm{H}-2,20-22 \mathrm{~cm}$, and $650 \mathrm{~A}-5 \mathrm{H}-6,5-7 \mathrm{~cm}$, are barren. Some samples below Section $650 \mathrm{~A}-6 \mathrm{H}-3$ contain rare individuals in varying assemblages: Bella digitata, Globigerina bulloides, G. quinqueloba, Globigerinita uvula, Globigerinoides cyclostomus, G. ruber, Globorotalia inflata, G. scitula, sinistral G. truncatulinoides excelsa, and dextral Neogloboquadrina pachyderma.

\section{Sedimentological Interpretation}

Grain size distribution, carbonate content, and content of shallow water biogenic material characterize this layer as turbidite.

\section{Stratigraphic Hypothesis}

Overlying sediment: Sample $650 \mathrm{~A}-5 \mathrm{H}-5,32-34 \mathrm{~cm}$ (from a turbidite), contains rare Globigerina quinqueloba (some larger than $125 \mu \mathrm{m})$, Globigerinita glutinata, and common Globigerina bulloides (larger than $200 \mu \mathrm{m}$ ). The assemblage predicates a cool environment.

The layer itself: no useful information.

Underlying sediment: All samples in Sections 650A-8H-1 through $650 \mathrm{~A}-8 \mathrm{H}-3$ are barren. The first sample bearing foraminifers is $650 \mathrm{~A}-8 \mathrm{H}-4,36-40 \mathrm{~cm}$. It contains a "temperate" assemblage with few Globigerina bulloides, Globorotalia inflata, and Neogloboquadrina dutertrei. Below this sample, in 650A$8 \mathrm{H}-4,92-96 \mathrm{~cm}$, we found beside planktonic foraminifers a mixture of the cold pteropod Limacina retroversa and Diacria trispinosa, a pteropod usually present in the warm isotope Stage 5e.

Result: From the occurrence of Diacria trispinosa in a mixture with cold pteropods, we conclude that the studied layer should be younger than isotope Stage $5 \mathrm{e}$.

\section{Layer 7 (Core 8, Section 4, 94-146 cm)}

The layer (thickness: $0.52 \mathrm{~m}$; depth below seafloor: $67.24-$ $67.76 \mathrm{~m}$ ) consists of a silty-sandy dark colored base (one sample) and a light-colored slightly laminated upper part (two samples). Grain size distribution (Fig. 9) shows a typical normallygraded sequence. Organic carbon and total carbonate contents are both stable at low levels within the slightly laminated upper part and are little higher and lower respectively in the base sample (Fig. 9). The clay mineral assemblages are characterized by the presence of illite and irregular mixed layer minerals and the predominance of kaolinite over chlorite.

The sand fraction of the base sample $(650 \mathrm{~A}-8 \mathrm{H}-4,145-146$ $\mathrm{cm}$ ) consists almost completely of shards of pumice, predominantly colorless or white, with spheric and (increasing in finer fractions) elongate vesicles. There occur also few shards of brownish pumice. Benthic and planktonic foraminifers are rare.

The benthic foraminifers (Table 1) show a mode of bathymetric distribution at upper epibathyal depth. 


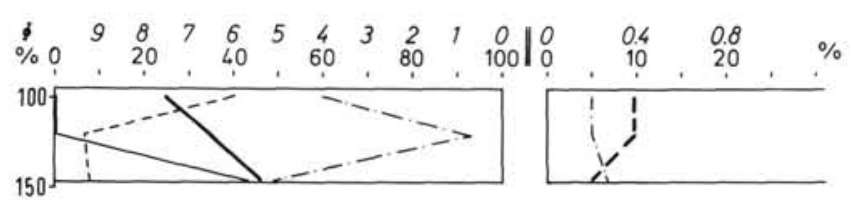

Figure 9. Sedimentological parameters for Core $650 \mathrm{~A}-8 \mathrm{H}$, Section 4 , $94-146 \mathrm{~cm}$. See Figure 2 for legend.

Planktonic foraminifers: The base sample $(650 \mathrm{~A}-8 \mathrm{H}-4,145-$ $147 \mathrm{~cm}$ ) contains Globigerina bulloides, G. quinqueloba, Globigerinita glutinata, Globigerinoides elongatus, Globorotalia inflata, dextral Neogloboquadrina pachyderma and Orbulina universa, the mixture of which simulates "temperate" environment. The top sample $(650 \mathrm{~A}-8 \mathrm{H}-4,92-96 \mathrm{~cm})$ contains the same assemblage with a mixture of the cold pteropod Limacina retroversa and the warm pteropod Diacria trispinosa.

\section{Sedimentological Interpretation}

Because of normal gradation and upcore-increase of carbonate content, this layer is interpreted as turbidite.

\section{Stratigraphic Hypothesis}

Overlying sediments: no useful information.

The layer itself: There is a contrast between the "temperate" foraminiferal assemblage, the cold Limacina retroversa, and Diacria trispinosa (usually characteristic for the warm isotope Stage 5e).

Underlying sediments: Sample $650 \mathrm{~A}-8 \mathrm{H}-5,38-42 \mathrm{~cm}$, seems to represent a normal, nonturbiditic sediment. Its planktonic foraminiferal assemblage (Globigerina glutinata, G. quinqueloba, Globigerinoides cyclostomus, G. elongatus, G. ruber, Globorotalia inflata, G. scitula, Neogloboquadrina acostaensis, $N$. dutertrei, and dextral $N$. pachyderma) indicates a temperate environment.

Result: According to the occurrence of obviously reworked Diacria trispinosa, the layer should be younger than isotope Stage 5e. The climatic indication of Sample 650A-8H-5, 38-42 $\mathrm{cm}$, is not useful.

\section{Layer 8 (Core 8, Section 6, $52 \mathrm{~cm}$ to Core 9, Section 3, $69 \mathrm{~cm}$ )}

The contact of this layer (thickness: $5.25 \mathrm{~m}$; depth below seafloor: $69.82-74.99 \mathrm{~m}$ ) with the underlying finely laminated sediment is sharp. The deepest part (Section 650A-9H-3) shows blurred laminae of centimeter size. The following interval in Section 650A-9H-2 (from base to $93 \mathrm{~cm}$ ) is somewhat soupy; internal structures cannot be observed. The interval $650 \mathrm{~A}-9 \mathrm{H}-2$, $22-93 \mathrm{~cm}$, shows fine lamination which is most clear in the deepest part. Finally, the upper part of the layer is nearly homogenous.

\section{General Textural Data}

Curves of grain size distribution, total carbonate, and organic carbon contents are shown on Figure 10.

Grain size distribution: In the deepest part of the layer, at first, the sand content increases and then (within Section 650A$9 \mathrm{H}-2$ ) decreases steadily to zero in favor of silt. Within Section $650 \mathrm{~A}-9 \mathrm{H}-1$, silt decreases in favor of clay. This is a normallygraded sequence. In the upper part of the studied layer (Sections $650 \mathrm{~A}-8 \mathrm{H}-\mathrm{CC}$ through $650 \mathrm{~A}-8 \mathrm{H}-6$ ), one more normallygraded sequence is perhaps documented. The sand content at the top of this sequence consists of glass shards and pumice with sticking pyrogenic crystals. These sand particles are possibly a contamination from the directly superposed coarser-grained layer.

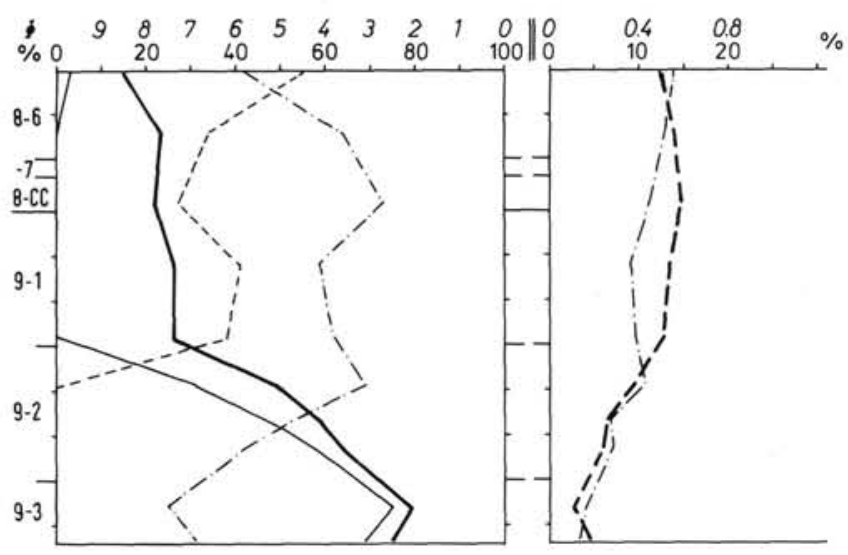

Figure 10. Sedimentological parameters for Core $650 \mathrm{~A}-8 \mathrm{H}$, Section 6 , $52 \mathrm{~cm}$, to Core $650 \mathrm{~A}-9 \mathrm{H}$, Section 3, $69 \mathrm{~cm}$. See Figure 2 for legend.

Organic carbon: increases nearly steadily from $0.12 \%$ (base) to $0.55 \%$ (top).

Total carbonate: decreases within the basal part of the layer when sand content increases, then increases from $3 \%$ to a maximum of $15 \%$ in Section $650 \mathrm{~A}-8 \mathrm{H}-\mathrm{CC}$ and decreases again toward the top of the layer. This tendency change could support the assumption derived from grain size distribution that the upper part of the studied layer (Sections 650A-8H-CC through -6 , $52 \mathrm{~cm}$ ) represents an individual fining-upward sequence.

Bulk mineralogy: quartz, calcite, feldspar, and mica.

Clay mineralogy: illite and irregular mixed layer minerals; kaolinite is dominating chlorite.

\section{Biogenic Content}

Bryozoans (very rare), echinoid spines, benthic (see Table 1) and planktonic foraminifers, ostracodes, pteropods, siliceous sponge spicules, and undetermined debris.

The bathymetric spectrum of benthic foraminifers in each horizon shows a mode of upper epibathyal depth (Fig. 3).

Planktonic foraminifers: In the base sample (650A-9H-3, 65$67 \mathrm{~cm}$ ) Globorotalia inflata is dominating as in Sample 650A$8 \mathrm{H}-5,38-42 \mathrm{~cm}$. Sample $650 \mathrm{~A}-9 \mathrm{H}-3,28-30 \mathrm{~cm}$, contains a similar assemblage. The samples between $650 \mathrm{~A}-9 \mathrm{H}-2,115-117 \mathrm{~cm}$, and $650 \mathrm{~A}-9 \mathrm{H}-1,58-60 \mathrm{~cm}$, are barren. In the upper part of the layer (Samples 650A-9H-1, 27-31 cm, and 650A-8H-CC), planktonic foraminiferal assemblages occur again which show compositions similar to the base sample. These observation supports the presumption that the studied layer consists of two separate turbidites, the upper one of which seems to begin already in Section 650A-9H-1.

\section{Nonbiogenic Components of Sand Fraction}

Main constituents are shards of glass and highly vesicular pumice of different vesicle shapes and dominating light colors, but also of brownish colors. The finer sand fractions at the base of the layer contain large amounts of feldspar and other mineral grains, the number of which decreases drastically upward. Low vesicular opaque lapilli of dark gray and red colors occur in all samples in few numbers.

\section{Sedimentological Interpretation}

It is most likely that the studied interval comprises two separate turbidites.

\section{Stratigraphic Hypothesis}

Overlying sediments: Sample $650 \mathrm{~A}-8 \mathrm{H}-5,38-42 \mathrm{~cm}$, gives no useful information. 
The layer itself: no useful information.

Underlying sediments: A useful sample (normal sedimentation?) seems to be $650 \mathrm{~A}-9 \mathrm{H}-3,142-146 \mathrm{~cm}$. Its assemblage is dominated by Globigerina bulloides (cold) and Globorotalia inflata (temperate). Moreover, there are rare Limacina retroversa (cold). This assemblage indicates a temperate cool environment. It is warmer than the maximum of the cold isotope Stage 6. Similar relations are observed from Sample 650A-9H-5, 34-38 $\mathrm{cm}$, where Globorotalia inflata dominates Globigerina bulloides.

Result: The studied layer can be situated within or above isotope Stages 4 or 6 . We favor Stage 4 because of the interpretation of Layer 9.

\section{Layer 9 (Core 11, Section 2, $58 \mathrm{~cm}$, to Core 14, CC)}

The thickness of this layer (thickness: $39.32 \mathrm{~m}$ ?; depth below seafloor: $92.78-132.1 \mathrm{~m}$ ?) cannot be exactly obtained, since the lower boundary is uncertain. Because of slowed drilling progress during Core $650 \mathrm{~A}-13 \mathrm{H}$, the coring method was changed from APC (Cores $650 \mathrm{~A}-1 \mathrm{H}$ through $650 \mathrm{~A}-13 \mathrm{H}$ ) to XCB (Cores $650 \mathrm{~A}-14 \mathrm{X}$ to base). This change resulted in a decreased recovery which is drastically demonstrated in Cores $650 \mathrm{~A}-13 \mathrm{H}(88.8 \%)$ and $650 \mathrm{~A}-14 \mathrm{X}(1.1 \%)$. The lithology of the $15 \mathrm{~cm}$ of sediment recovered in Core 650A-14X does not really differ from that of Core $650 \mathrm{~A}-13 \mathrm{H}$ sediments. Therefore, we can assume that the complete length of Core 650A-14X should consist of the same less-cohesive sediment which, however, has been washed out nearly completely due to the more powerful coring method.

\section{General Textural Data}

Some textural data are compiled in Figure 11. The others and details of the previous ones are described as follows.

Grain size: Within the deeper part (from base to about the section boundary $650 \mathrm{~A}-12 \mathrm{H}-3 / 650 \mathrm{~A}-12 \mathrm{H}-4$ ) the sediment is dominated by the sand fraction, whereas silt and clay fractions do not exceed $25 \%$ and $5 \%$ respectively. Within Sections $650 \mathrm{~A}$ $12 \mathrm{H}-3$ and $650 \mathrm{~A}-12 \mathrm{H}-2$, the sand content decreases to less than $5 \%$ and, with the opposite tendency, silt content increases to about $90 \%$. In the course of the upper part of this layer, the silt content decreases generally but oscillatingly to $40 \%$ minimum and clay content increases respectively, whereas, sand sized particles are very rare. This is a typical normally-graded sequence. The uppermost sample $(650 \mathrm{~A}-11 \mathrm{H}-2,59-61 \mathrm{~cm})$ shows a rapid increase of sand content again $(22 \%)$ which is easily explained by the considerable amount of planktonic foraminifers.

Total carbonate: Within the sandy lower part of the layer, the carbonate content is low (3\%-7\%). Within the interval of decreasing sand content, the carbonate values increase oscillatingly to about $10 \%$, then they increase steadily to $20 \%$, and finally (uppermost sample) reach $27 \%$. This maximum value is considerably less than in normal open marine sediments, but represents one of the highest values within lithological Unit I of the initial core description.

Organic carbon: The content of organic carbon is generally low (between $0.05 \%$ and $0.3 \%$ ) and shows nearly the same tendencies as the total carbonate.

Carbonate mineralogy: In many cases, the carbonates are represented by calcite only. Its $\mathrm{MgCO}_{3}$ content varies in the deeper part (corresponding with the sand size dominated interval) between $1.5 \%$ and $4.5 \%$ with maximum around $2 \%$, and shows less variations $(1.5 \%-2.5 \%)$ in the upper part of the sequence. Dolomite is documented within the interval from Section $650 \mathrm{~A}-11 \mathrm{H}-7$ to $650 \mathrm{~A}-11 \mathrm{H}-2,90 \mathrm{~cm}$, however, always near the identification limit. Therefore, its quantity has not been calculated.

Bulk mineralogy: Two different bulk mineralogy assemblages have been distinguished: (1) quartz, feldspar, hornblende, py-

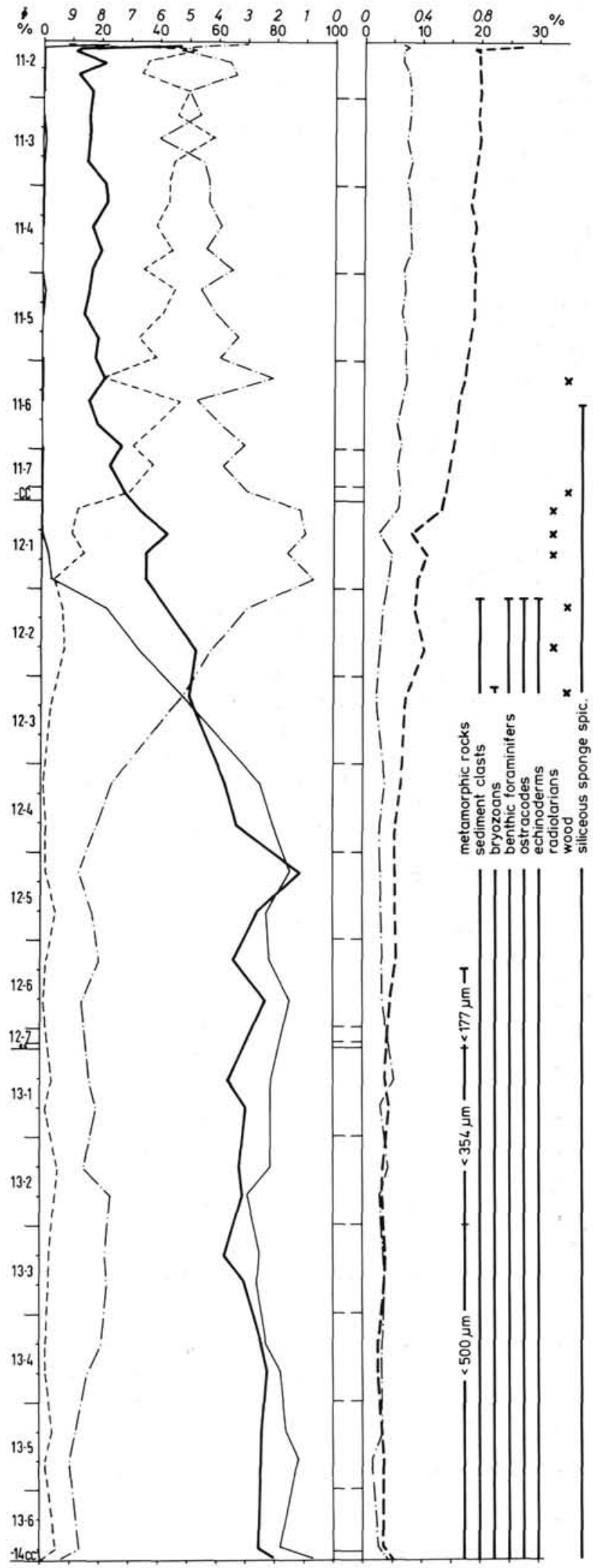

Figure 11. Sedimentological parameters for Core 650A-11H, Section 2, $58 \mathrm{~cm}$, to Core $650 \mathrm{~A}-14 \mathrm{X}-\mathrm{CC}$. Occurrences of important sand components are indicated. See Figure 2 for legend. 
roxene, palagonite, and calcite (base to Sample 650A-12H-1, $55-57 \mathrm{~cm}$ ); the palagonite indication becomes weaker in Sections $650 \mathrm{~A}-12 \mathrm{H}-4$ through $650 \mathrm{~A}-12 \mathrm{H}-1$; and (2) quartz, calcite and dolomite, less feldspar than in assemblage (1), traces or lack of hornblende, pyroxene, and palagonite (Sample 650A$12 \mathrm{H}-1,15-17 \mathrm{~cm}$, to top). Within this interval, the content of feldspar decreases again above Sample 650A-11 H-5, 29-31 cm.

Clay mineralogy: Depending on the quantity of clay size fraction, the analysis has been made only for the interval from Sample $650 \mathrm{~A}-12 \mathrm{H}-2,105-107 \mathrm{~cm}$, to top. This interval shows a nearly uniform clay mineral assemblage: illite is most frequent with $53 \%-65 \%$. The content of $7 \AA$ minerals (kaolinite and chlorite) amounts to $35 \%-47 \%$; kaolinite always dominates chlorite in a relation of about $3: 1$. No smectite has been observed, but a broad area of irregular mixed layer minerals always occurs in the $\mathrm{x}$-ray records.

\section{Biogenic Content}

A broad spectrum of biogenic components occur within the sediments of this layer. Some of the groups have been studied in detail in order to get precise information. The other ones are only reported since their environmental indication is self-evident or of minor value.

Bryozoans: broad morphological spectrum of skeletal fragments (within deeper part up to Sample 650A-12H-3, 35-37 cm).

Echinoderms: fragments of spines and different skeletal elements (within deeper part up to Sample 650A-12H-2, 35-37 cm).

Benthic foraminifers: Complete list and details of occurrence on Table 1. Benthic foraminifers have been found from base to Sample $650 \mathrm{~A}-12 \mathrm{H}-2,35-37 \mathrm{~cm}$, and in two samples from the silt-dominated upper part of the layer (out of our sample pattern and with larger sediment volume). Additional samples with larger sediment volume (all the $116-120 \mathrm{~cm}$ samples) have been studied also from the sand-dominated deeper part of the layer. The main results are:

1. Samples of "good quality" ( $>50$ specimens) are arranged in the upper part of the sand-dominated interval. The samples of the deeper part (up to Sample 650A-13H-3, 100-102 cm) contain almost always less than 50 specimens each (even the samples of large volume). The samples above Sample 650A-12H-3, 35-37 cm contain less than 10 specimens each.

2. Few reworked specimens occur within most of the samples.

3. The spectrum of bathymetric zones is widely expanded from upper neritic to lower mesobathyal, but its mode is usually upper epibathyal through the sequence (Fig. 3).

4. The percentage of shallow water species (depth intervals 1 and 2) varies in samples of "good quality" between $17 \%$ and $64 \%$.

5. The broken specimens almost always dominate the unbroken ones (up to $89 \%$ ).

Obviously, the benthic foraminifera indicate the provenance of the material of this layer from shallow water environments including the upper shelf. Their occurrence within the layer is most likely dependent on their transportation and deposition properties.

Planktonic foraminifers: They occur as a common component within the sand-dominated deeper part of the layer up to Sample $650 \mathrm{~A}-12 \mathrm{H}-2,35-37 \mathrm{~cm}$. Within the upper part, small tests of planktonic foraminifers (about $200 \mu \mathrm{m}$ maximum) occur only sporadically. In contrast, the uppermost sample $(650 \mathrm{~A}$ $11 \mathrm{H}-2,59-61 \mathrm{~cm})$ contains a considerable amount of plank- tonic foraminifers which (according to the relatively high total carbonate value; see above and Fig. 11) indicates a nearly normal sedimentation.

In the base sample (650A-14X-CC, $12-14 \mathrm{~cm}$ ), planktonic foraminifers are rare and moderately preserved. Globorotalia inflata is dominant with rare Globigerinoides ruber and Orbulina universa. In Sample 650A-13H-CC, number and preservation are similar. The assemblage contains additionally rare dextral Neogloboquadrina pachyderma and sinistral Globorotalia truncatulinoides excelsa.

We studied 23 samples from Core $650 \mathrm{~A}-13 \mathrm{H}$. In all of them, Globorotalia inflata is the dominant species, but in detail the artificial associations are diversified. In some of them, Globorotalia truncatulinoides excelsa occurs dextrally or sinistrally coiled or both. In some samples Globigerina bulloides is well represented giving a "temperate cool" impression, in others the warmer species Globigerinoides ruber occurs, its pink variety (often observed in connection with warm sapropelic levels) appears in $650 \mathrm{~A}-13 \mathrm{H}-2,100-102 \mathrm{~cm}$. In the finest sand fractions, there are only few planktonic foraminifers. This is in contrast to true hemipelagic sediments.

Similar mixtures occur in Core $650 \mathrm{~A}-12 \mathrm{H}$ where we studied 25 samples and noted the occurrence of Neogloboquadrina dutertrei in $650 \mathrm{~A}-12 \mathrm{H}-5,35-37 \mathrm{~cm}, 650 \mathrm{~A}-12 \mathrm{H}-4,92-96 \mathrm{~cm}$, and $650 \mathrm{~A}-12 \mathrm{H}-3,28-30 \mathrm{~cm}$. Between $650 \mathrm{~A}-12 \mathrm{H}-1,135-137 \mathrm{~cm}$, and $650 \mathrm{~A}-11 \mathrm{H}-3,109-111 \mathrm{~cm}$, only 2 of 29 samples contain planktonic foraminifers. In Sample 650A-11H-CC, we found rare Orbulina universa, sinistral Globorotalia truncatulinoides excelsa, Globigerinella siphonifera, and Globigerinita glutinata. In Sample $650 \mathrm{~A}-11 \mathrm{H}-4,69-71 \mathrm{~cm}$, few juvenile Globorotalia inflata and Globigerina bulloides occur.

The assemblage of the top sample $(650 \mathrm{~A}-11 \mathrm{H}-2,59-61 \mathrm{~cm})$ is described in discussion "Stratigraphic Hypothesis" below.

Gastropods: debris of ornamented conical gastropods and of pteropods (from base to Sample 650A-12 H-3, 35-37 cm).

Nannoplankton: Based on the nannoplankton biostratigraphy, the layer belongs to Zone NN21. For our problem, the nannoplankton assemblages were studied with regard to ratio autochthonous/reworked species and the total content of nannoplankton. The total number of species varies considerably. Within almost all samples, reworked species occur with wide variations. Autochthonous species occur only within a minority of the samples and seem to become more frequent toward the top of the layer.

Ostracodes: Ostracode tests have been found in all samples from base to Sample $650 \mathrm{~A}-12 \mathrm{H}-2,35-37 \mathrm{~cm}$. The list of species is presented on Table 2. The origin of the species is shown on Table 3. In some cases "autochthonous" ostracodes occur when allochthonous ones are plentiful. The average size of "in-situ" fauna $(1 \mathrm{~mm})$ is twice as large as that of the allochthonous one $(0.5 \mathrm{~mm})$. The "autochthonous" assemblage (small numbers and slightly diversified) is typical for present-day deep-water environments $(>2500 \mathrm{~m}$ ) of the western Mediterranean (Peypouquet and Nachite, 1984; Nachite, 1984). This interpretation is supported by the predominance of Bythocypris obtusata (Peypouquet and Hamoudi, this volume). Allochthonous ostracodes occur in all samples analyzed. Following characteristics have to be noted:

1. Few mesohaline species like Loxoconcha elliptica or Cypris pubera suggest the existence of continental inputs;

2. Most of the forms detected belong to inner coastal environments (5-30 m water depth) and, above all, to phytal domains (sea-grass, phanerogames). Major genera identified: Loxoconcha, Aurila, Semicytherura, Neocythereis; and 
Table 2. Distribution of ostracodes in Layer 9 (Core 650A-11H-2, $58 \mathrm{~cm}$, to Core 650A-14XCC). ${ }^{a}$

$\begin{array}{lllllllllllllllllll}1 & 2 & 3 & 4 & 5 & 6 & 7 & 8 & 9 & 10 & 11 & 12 & 13 & 14 & 15 & 16 & 17 & 18 & 19\end{array}$

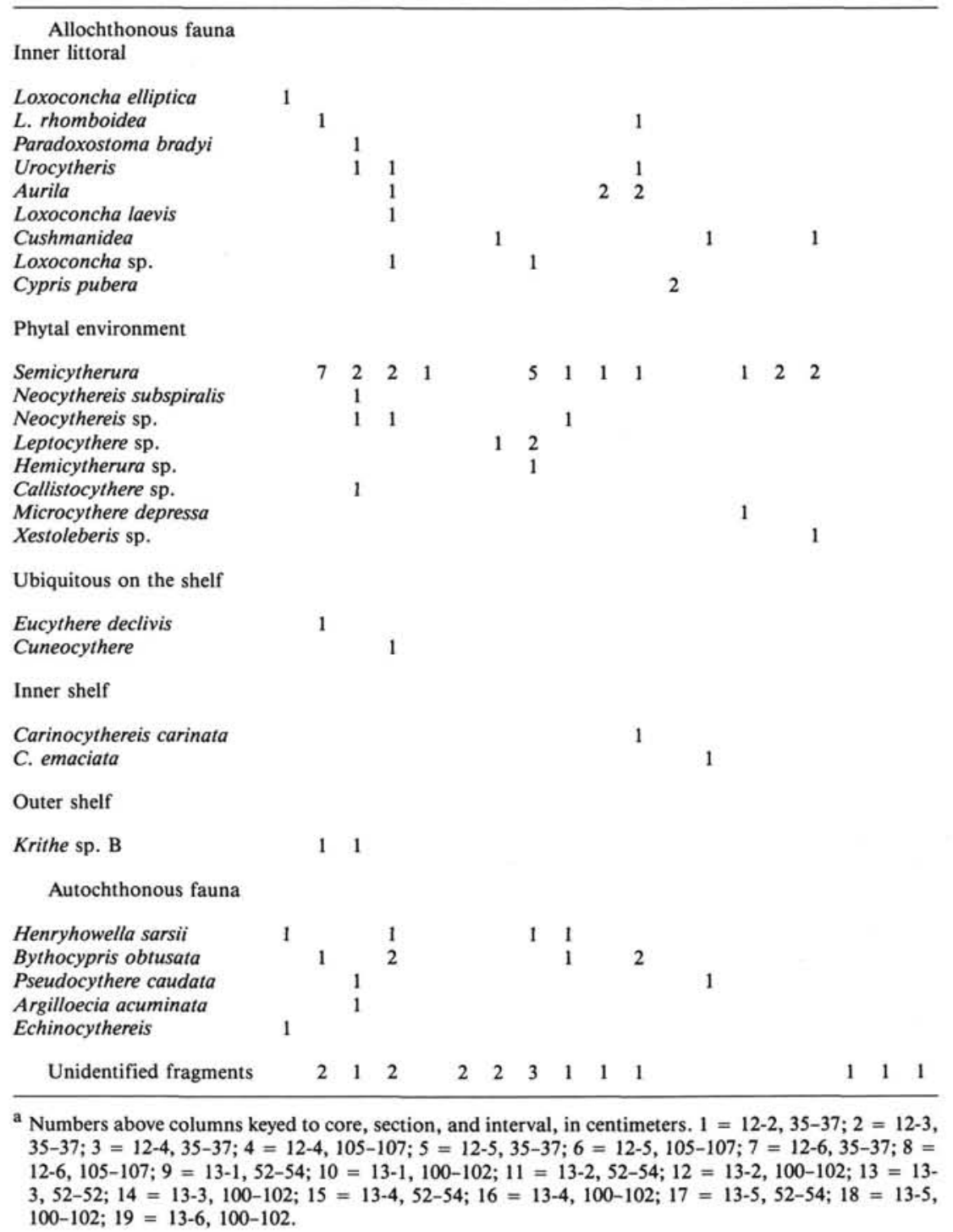

3. Ubiquitous species occur far less frequently over the entire continental shelf; even some rare Krithe sp. B (Peypouquet, 1977) have been detected living on the outer shelf.

The co-occurrence of allochthonous and "autochthonous" species can be explained by reworking of recent to subrecent sediments in water depths of more than $2500 \mathrm{~m}$ by the turbidity current (already laden with shallow water ostracodes) and winnowing effects within the turbulent environment which enrich both types of ostracodes in respective levels within the graded sequence. Therefore, the term "autochthonous" can be understood only as "originated from the deepest water depth interval,"

Pelecypods: carbonate shells of juvenile pelecypods with vitreous walls. (within almost all samples from base to Sample $650 \mathrm{~A}-12 \mathrm{H}-2,35-37 \mathrm{~cm}$ ).

Plant remains: debris of conifers (rare, within silt-dominated sediments; Sections $650 \mathrm{~A}-12 \mathrm{H}-2$ and -3 , and Sections $650 \mathrm{~A}$ $11 \mathrm{H}-6$ and $-\mathrm{CC})$.
Porifera: siliceous sponge spicules (tetraxone, orthotriaene, dichotriaene, rhizoclone). Continuously present from base to Sample $650 \mathrm{~A}-11 \mathrm{H}-6,69-71 \mathrm{~cm}$, and in three samples of Sections $650 \mathrm{~A}-11 \mathrm{H}-2$ and -3 .

Radiolarians: only few specimens in Sections 650A-12H-1 and -2 . Relatively well preserved, even if broken.

\section{Components of Sand Fraction}

The composition of the sand fraction is very complex. It varies within the grain size fractions of each sample as well as within the sand-dominated part of the sequence from base to top. Plate 1, Figures 3 and 4 demonstrate the change of composition from base of the layer to top of the sand-dominated interval by means of fraction $125-177 \mu \mathrm{m}$.

Main constituents are different types of volcaniclastic particles:

1. Pumice shards of different size, high vesicularity, and different size of vesicles (Pl. 2, Fig. 1): (a) elongate, light gray to 
Table 3. Ecological significance of ostracode faunas from Layer 9 (Core 11, Section 2, $58 \mathrm{~cm}$, to Core $14, \mathrm{CC}$ ).

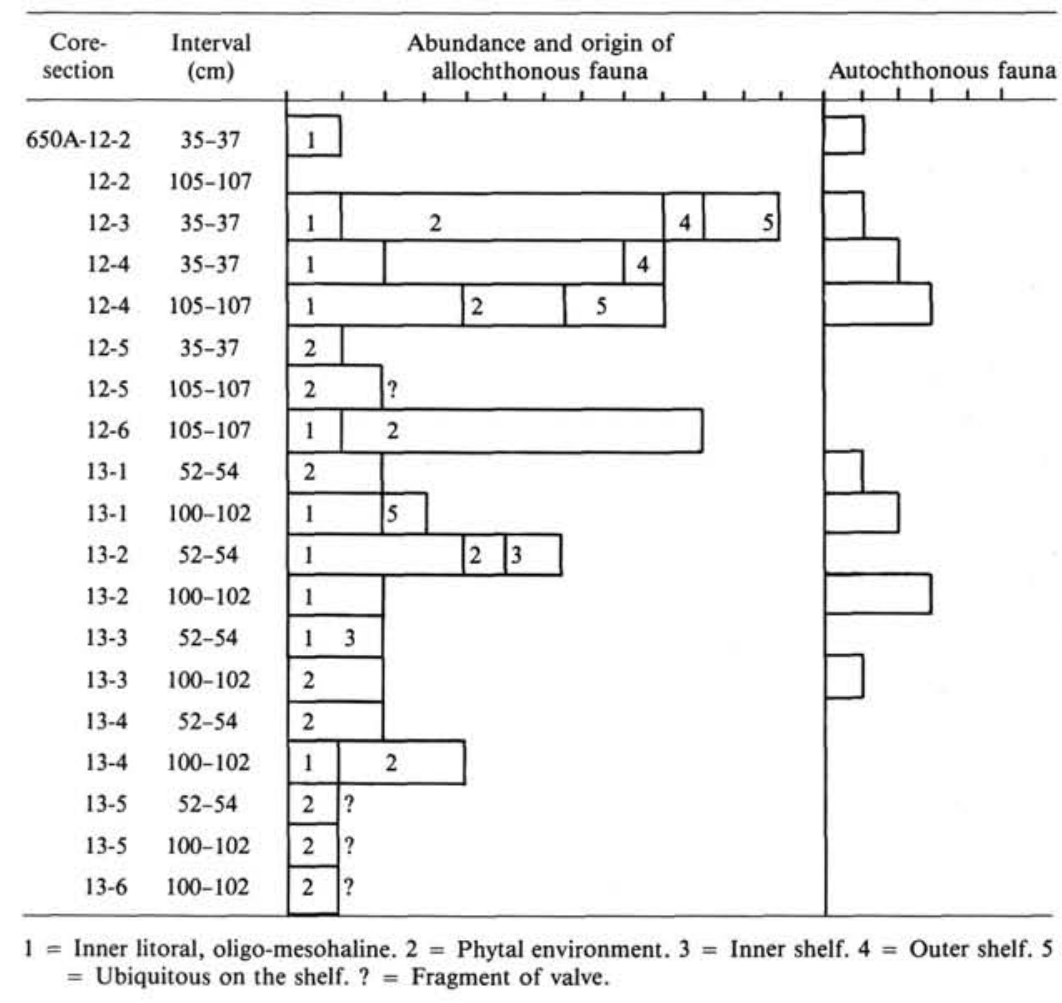

colorless, less frequently brownish, sometimes including pyrogenic crystals (Pl. 2, Fig. 2); (b) equant, with globular vesicles, brownish colors (Pl. 2, Figs. 3-5).

2. Pumice lapilli of low vesicularity, with smooth or rough surfaces, gray to black and reddish colors (PI. 3).

Additionally, following components occur with varying frequencies:

1. K-feldspar and plagioclase;

2. Quartz;

3. Hornblende, augite;

4. Biotite;

5. Fragments of metamorphic rocks (preliminary, R. Sartori and G. Zuffa, pers. comm., 1987): low-grade phillites, mostly sericitic; quartz-biotite medium- to high-grade metamorphic rocks;

6. Greenish clasts with possible pyroxenes (ophiolite suites?) (preliminary, R. Sartori and G. Zuffa, pers. comm., 1987);

7. Clasts of sediments (Pl. 4, Fig. 1) containing volcaniclastic particles, mineral grains (quartz, feldspar, hornblende), fragments of metamorphic rocks, planktonic foraminifers, ostracodes (internal mold; Pl. 4, Fig. 3), nannoplankton.

The existence of internal molds and the only gradual disintegration of the clasts during ultrasonic preparation indicate a certain lithification and point to a somewhat higher age for these reworked sediments.

Because of possible partial disintegration of sediment clasts during preparation, we have to expect that some of the mineral and biogenic grains of the complete sediment may be derived from such clasts. The same effect, however, may have occurred during the transport of reworked sediments.

All biogenic materials mentioned in the preceding paragraph except nannoplankton are components of the sand fraction.
Their occurrence and frequency within the whole sand-dominated part of the layer depend obviously on their deposition properties. Planktonic and benthic foraminifera are rare within the deepest part but common within the higher parts of the sand-dominated interval (PI. 1, Figs. 3 and 4). Within the whole sand-dominated interval, bryozoan debris occurs as well as ostracodes and debris of echinoderms, but disappears within the interval of transition from sand- to silt-dominance somewhat earlier than the others. In contrast, radiolarians and wood occur only around the transition interval. Siliceous sponge spicules are a constant component from base into the silt-dominated interval (see Fig. 11).

Comparable relations can be observed for the nonbiogenic components. Maximum size and frequency of metamorphic rock fragments and sediment clasts decrease upward. Mineral grains and pumice shards of low vesicularity dominate in basal parts of the layer whereas shards of high vesicularity are most frequent in upper parts (Pl. 1, Figs. 3 and 4).

\section{Sedimentological Interpretation}

A turbidite of unusually great thickness. The turbidity current obviously started from a shallow water region and eroded older, slightly cemented sediments on its way to the deep.

\section{Stratigraphic Hypothesis}

Overlying sediments: no useful information.

The layer itself: The uppermost sample $(650 \mathrm{~A}-11 \mathrm{H}-2,59-61$ $\mathrm{cm}$ ) contains an assemblage characterized by the abundant occurrence of Globorotalia inflata and Orbulina universa (some $>500 \mu \mathrm{m}$ ) with large dextral Neogloboquadrina pachyderma $(>125 \mu \mathrm{m})$. The co-occurrence of some dextral Globorotalia truncatulinoides excelsa with common Globigerinella siphonifera allows us to propose a temperature interval during Stage 5. (Stage 4 is characterized by the abundance of Globorotalia inflata associated with Orbulina, however, G. siphonifera has never 
been found in Stage 4 sediments.) Stage 5 is incomplete in the sedimentary sequences of all Leg 107 Sites. It is difficult to decide whether this assemblage is indicating Stage $5 \mathrm{~b}(90,000 \mathrm{yr})$ or Stage $5 \mathrm{~d}(110,000 \mathrm{yr})$.

Underlying sediments: Bad recovery and barren samples in Core $650 \mathrm{~A}-15 \mathrm{X}$ prevented obtaining information. A fix datum is the boundary between nannoplankton zones NN20 and NN21 in Core 650A-16X (Shipboard Scientific Party, 1987, p. 149).

Results: According to the interpretation of its top sample, the studied layer is interpreted to be situated within isotope Stage 5 .

\section{Layer 10 (Core 17, Section 1, 74-121 cm)}

The layer (thickness: $0.47 \mathrm{~m}$; depth below seafloor: $152.04-$ $152.51 \mathrm{~m}$ ) is macroscopically subdivided into (1) 9-cm-thick siltysandy base, (2) 3-cm-thick laminated interval, (3) 27-cm-thick structureless interval, and (4) 8-cm-thick light colored interval with few darker laminae. The bottom contact is sharp, the top contact seems to be somewhat disturbed by drilling.

\section{General Textural Data}

Grain size distribution and contents of organic carbon and total carbonate are presented on Figure 12.

Grain size distribution: shows a normally-graded sequence.

Organic carbon: The content is almost constant at about $0.4 \%$ except of base and top of the layer $(0.2 \%-0.3 \%)$.

Total carbonate: The content increases steadily from $22 \%$ (base) to $31 \%$ (top).

Carbonate mineralogy: Calcite is always dominating component. Its $\mathrm{MgCO}_{3}$ content varies between $2 \%$ and $3 \%$ with the maximum at $2 \%$. Dolomite amounts usually to about $5 \%$ of total carbonate and does not exceed $10 \%$.

Bulk mineralogy: The mineralogical assemblage is more or less constant: quartz, calcite, dolomite, feldspar, mica, chlorite, and palagonite. Pyroxene occurs only in the base sample.

Clay mineralogy: There occur two assemblages (obtained from only three samples): (1) illite $78 \%, 7 \AA$ minerals (dominated by chlorite) $22 \%$, neither mixed layer minerals nor smectite; in Sample 650A-17X-1, 119-121 cm; (2) illite 71\%-73\%, 7£ minerals (dominated by kaolinite) $27 \%-29 \%$, broad band of illitesmectite mixed layer minerals, smectite not clearly identified; in Samples 650A-17X-1, 95-97 cm, and 650A-17X-1, 74-76 cm.

\section{Biogenic Content}

Echinoderms: few debris in Sample 650A-17X-1, 114-116 cm (interval 1).

Benthic foraminifers: in the base sample (650A-17X-1, 119$121 \mathrm{~cm}$ ) 3 unbroken and 18 broken specimens (details on Table 1). There, not only shallower water depth species (zones 1,2 , and 3), but also lower mesobathyal species are frequent (Fig. 3).

Planktonic foraminifers: The base sample (650A-17X-1, 119$121 \mathrm{~cm}$ ) is dominated by Globigerina bulloides with some dextral Neogloboquadrina pachyderma. The following samples until $650 \mathrm{~A}-17 \mathrm{X}-1,104-106 \mathrm{~cm}$, contain generally very few individuals (dextral N. pachyderma, Globorotalia inflata, and Globigerina bulloides). The samples between $650 \mathrm{~A}-17 \mathrm{X}-1,95-97 \mathrm{~cm}$, and $650 \mathrm{~A}-17 \mathrm{X}-1,84-86 \mathrm{~cm}$, are barren.

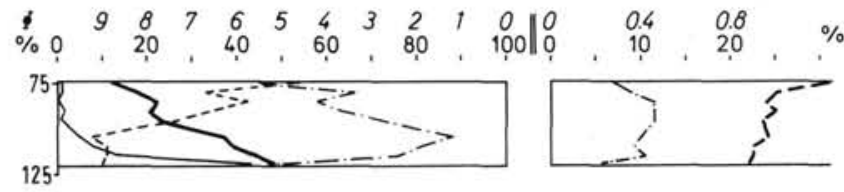

Figure 12. Sedimentological parameters for Core 650A-17X, Section 1, $74-121 \mathrm{~cm}$. See Figure 2 for legend.
The sand fractions of both samples in interval (4) (650A$17 \mathrm{X}-1,79-81 \mathrm{~cm}$, and $650 \mathrm{~A}-17 \mathrm{X}-1,74-76 \mathrm{~cm})$ consist of almost only planktonic foraminifers. The top sample shows a very well preserved assemblage consisting only of Globigerina bulloides with rare dextral Neogloboquadrina pachyderma which corresponds well with Sample 653A-2H-6, 91-95 cm. Sample 650A$17 \mathrm{X}-1,79-81 \mathrm{~cm}$, has a more diversified composition: dominant Globigerina bulloides, few dextral Neogloboquadrina pachyderma as well as abundant Globigerina quinqueloba, some Orbulina universa and dextral Neogloboquadrina dutertrei. There occur also fragments of foraminiferal tests which seem to show dissolution.

Nannoplankton: The studied layer is situated at the top of Zone NN20. Autochthonous nannoplankton is abundant only in the top sample. There, reworked nannoplankton is very rare. In contrast, the other samples contain only rare to very rare autochthonous species but in most cases Pliocene and reworked Quaternary species.

Plant remains: several specimens including wood in Sample 650A-17X-1, 114-116 cm (interval 1).

Porifera: siliceous sponge spicules occur rarely in Sample $650 \mathrm{~A}-17 \mathrm{X}-1,79-81 \mathrm{~cm}$ (interval 4), and more frequently in the two samples of interval (1).

Pteropods: in samples of interval (1).

Undetermined: debris of calcareous shells.

\section{Nonbiogenic Components of Sand Fraction}

The composition of the sand fraction is very complex. It varies within the grain size fractions of each sample as well as within the sedimentary sequence from base to top.

Volcaniclastic material dominates in Samples 650A-17X-1, $119-121 \mathrm{~cm}(>500 \mu \mathrm{m}), 650 \mathrm{~A}-17 \mathrm{X}-1,114-116 \mathrm{~cm}(>1000 \mu \mathrm{m})$, $650 \mathrm{~A}-17 \mathrm{X}-1,109-111 \mathrm{~cm}(>354 \mu \mathrm{m}), 650 \mathrm{~A}-17 \mathrm{X}-1,104-106 \mathrm{~cm}$ $(>250 \mu \mathrm{m})$, and $650 \mathrm{~A}-17 \mathrm{X}-1,89-91 \mathrm{~cm}(>354 \mu \mathrm{m})$. There are opaque, red and dark brown to black lapilli of low vesicularity, sometimes with pyrogenic minerals; glass shards, dark gray to colorless, highly vesicular with elongate vesicles, and brownish ones with spheric vesicles.

In connection with the volcaniclastic material are some grains of feldspar and subrounded quartz as well as fragments of metamorphic rocks (quartz-biotite rocks and low-grade phyllites).

Grains of quartz, feldspar, and undetermined minerals dominate the $<125-\mu \mathrm{m}$-fraction of the three deepest samples with tendency of decreasing grain size upcore. Mica is a prominent component of the four deepest samples (also with distinct tendency of upcore-decreasing grain size).

Few clasts of somewhat lithified sediment occur in Sample $650 \mathrm{~A}-17 \mathrm{X}-1,104-106 \mathrm{~cm}$.

Planktonic foraminifers show a sinusoidal distribution within this layer; decreasing frequency and grain size within the deeper part and increasing within the upper part. This can be explained as follows: normal gradation of foraminifers as clastic components in the deeper part and a tendency to normal pelagic sedimentation in the upper part.

\section{Sedimentological Interpretation}

All observations (normal gradation, upcore-increasing carbonate content, two different clay mineral assemblages, shallow water benthic foraminifers, plant remains, distributions of planktonic foraminifers and nannoplankton, subrounded quartz grains, metamorphic rocks) support the interpretation as a turbidite with a "normal" hemipelagic top sediment.

The observations that in the base sample (1) Articulina tubulosa (indicative for bathymetric zone $7=$ lower mesobathyal) occurs as frequent as the benthic foraminifers of shallower water, and (2) the sand content is relatively small (compared with 
layer 9; Fig. 11) suggest the idea that we can interpret this turbidite layer as a distal one.

\section{Stratigraphic Hypothesis}

Overlying sediments: The nannoplankton zone boundary NN20/NN22 is situated in Core 650A-16X (Shipboard. Scientific Party, 1987, p. 149).

The layer itself: The top sample $(650 \mathrm{~A}-17 \mathrm{X}-1,74-76 \mathrm{~cm})$ is compared with Sample 653A-2H-6, 91-95 cm, which is located near Termination III of Broecker and Van Donk, 1970 (uppermost part of isotope Stage 8).

Underlying sediments: Samples from Core $650 \mathrm{~A}-18 \mathrm{X}$ show always a mixture of cool assemblages with warmer species like Globigerinoides ruber and Globigerina falconensis.

Result: The studied layer is considered to be deposited during the uppermost part of isotope Stage 8 .

\section{Layer 11 (Core 20, Section 1, $67 \mathrm{~cm}$, to Section 20, CC)}

In this layer (thickness: $1.40 \mathrm{~m}$; depth below seafloor: $180.47-$ $181.85 \mathrm{~m}$ ), only the interval $650 \mathrm{~A}-20 \mathrm{X} 1,67-135 \mathrm{~cm}$, has been sampled in detail. An additional sample was taken from 650A20X-CC, $13-15 \mathrm{~cm}$.

The deeper part consists of silty-sandy sediments with more or less intensive drilling disturbance. The interbedding of coarserand finer-grained sediments in Section 2 may represent true sedimentary sequences as well. The upper part (Section 650A-20X-1, above $120 \mathrm{~cm}$ ) is nearly structureless and becomes light-colored toward the top.

\section{General Textural Data}

Grain size distribution and contents of organic carbon and total carbonate are presented on Figure 13.

Grain size distribution: The well sampled interval (Section $650 \mathrm{~A}-20 \mathrm{X}-1,135 \mathrm{~cm}$, to top) documents a normally-graded sequence. The increase of sand fraction within the light-colored clayey sediments at the top is due to the increase of planktonic foraminifer content.

It is problematical to interpret the deeper part of the layer. The only sample from $650 \mathrm{~A}-20 \mathrm{X}-\mathrm{CC}$ does not support the idea of an increasing content of sand size below the well sampled interval. Perhaps, we have to consider the sediment interval of Sections $650 \mathrm{~A}-20 \mathrm{X}-2$ and $650 \mathrm{~A}-20 \mathrm{X}-\mathrm{CC}$ as an individual normally-graded sequence with a gross lamination in Section 650A$20 \mathrm{X}-2$. However, we can also speculate that the whole badly sampled deeper part has only a slight variation in the grain size spectrum, according to that reported from the thick turbidite layer of Layer 9 (Fig. 11).

Organic carbon: Low content (around $0.2 \%$ ) within the coarsest sediments at the base, distinct increase to $0.4 \%$ in the sample of highest silt content, and then steady decrease to $0.2 \%$.

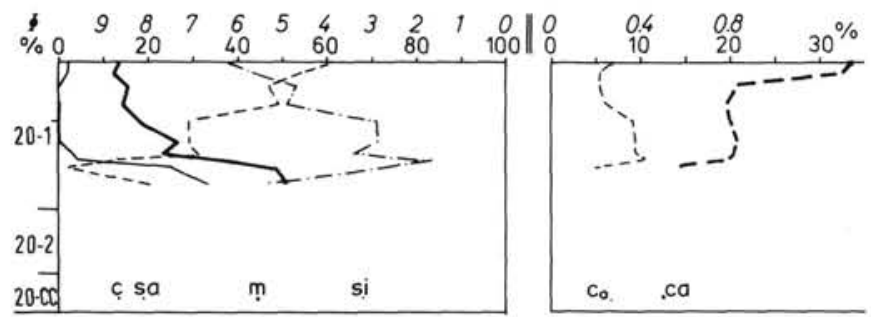

Figure 13. Sedimentological parameters for Core 650A-20X, Sections 1 , $67 \mathrm{~cm}$ to CC. Left side diagram: $\mathrm{c}=$ clay; $\mathrm{sa}=$ sand; $\mathrm{si}=$ silt $; \mathrm{m}=$ mean size. Right side diagram: $\mathrm{c}_{\mathrm{o}}=$ organic carbon, $\mathrm{ca}=$ total carbonate.
Total carbonate: Low content $(13 \%-15 \%)$ within the coarsest sediments at the base, distinct increase in the silt maximum sample $(20 \%)$, nearly constant content (about $20 \%$ ) within the greatest part of the structureless interval, and distinct increase to $33 \%$ within the uppermost centimeters (identical with the light-colored interval).

Carbonate mineralogy: Calcite is nearly the only component (dolomite has been found in some samples close to the identification limit). $\mathrm{MgCO}_{3}$ content of calcite varies between $1.5 \%$ and $2.75 \%$.

Bulk mineralogy: Impoverishment of mineral assemblages from base to top. Base sample: quartz, calcite, feldspar, chlorite, hornblende, mica, palagonite, pyrite, and pyroxene. In Sample $650 \mathrm{~A}-20 \mathrm{X}-1,110-112 \mathrm{~cm}$, pyrite disappeared. In Sample 650A-20X-1, 99-101 cm, palagonite disappeared. Sample 650A$20 \mathrm{X}-1,79-81 \mathrm{~cm}$, to top, chlorite content uncertain and decreased feldspar content.

Clay mineralogy: The assemblage is constant within the upper layer (three samples; from the deeper part of the layer data are not yet available): illite $86 \%-88 \%, 7 \AA$ minerals (dominated by chlorite) $12 \%-14 \%$, no mixed layer minerals, no smectite.

\section{Biogenic Content}

Echinoderms: few fragments of spines in Sample 650A-20X-1, $120-122 \mathrm{~cm}$.

Benthic foraminifers: Only in three samples; for details, see Table 1. The histogram of Sample 650A-20X-1, 124-126 cm (Fig. 3), shows a bimodal distribution. The smaller peak represents the inner neritic, and the larger one the lower mesobathyal zone.

Planktonic foraminifers: In addition to the samples for the sedimentological study, there exist two more samples taken for micropaleontological studies between $650 \mathrm{~A}-20 \mathrm{X}-1,133-135 \mathrm{~cm}$, and $650 \mathrm{~A}-20 \mathrm{X}-\mathrm{CC}, 13-15 \mathrm{~cm}$. In the base sample (650A-20X-CC, $13-15 \mathrm{~cm}$ ) planktonic foraminifers occur only in size fractions between 125 and $500 \mu \mathrm{m}$ but are rare (Globigerina bulloides, $G$. quinqueloba, Globigerinita glutinata, Globorotalia scitula, dextral Neogloboquadrina dutertrei, and Orbulina universa). In Sample 650 A-20X-2, 21-25 cm, there is a similar size distribution. Beside others, Globorotalia inflata occurs rarely. The samples following upcore are barren or contain only few small-sized individuals. The top samples $(650 \mathrm{~A}-20 \mathrm{X}-1,67-72 \mathrm{~cm})$ represent quite a normal sedimentation with Globigerina quinqueloba (abundant), G. quadrilatera and Globorotalia inflata (common), few G. scitula, Neogloboquadrina dutertrei, Orbulina universa (many larger than $500 \mu \mathrm{m}$ ), Globigerina cariacoensis, and dextral and sinistral Globorotalia truncatulinoides excelsa. In the topmost sample Globigerinella siphonifera is rare.

Holothurians: few skeletal elements in Sample 650A-20X-1, $120-122 \mathrm{~cm}$.

Nannoplankton: The layer belongs to Zone NN20. Autochthonous species are common in the two top samples (representing the light-colored interval) but are rare to missing in the other samples. Reworked Pliocene species occur in all samples except the two uppermost ones and in 650A-20X-1, 124-126 cm. Sample $650 \mathrm{~A}-20 \mathrm{X}-1,120-122 \mathrm{~cm}$, contains also reworked species older than Pliocene.

Plant remains: few specimens in Sample 650A-20X-1, 120$122 \mathrm{~cm}$

Porifera: siliceous sponge spicules (orthotriaene, dichotriaene, rhizoclone) in Samples $650 \mathrm{~A}-20 \mathrm{X}-1,124-126 \mathrm{~cm}$, and $650 \mathrm{~A}-$ $20 \mathrm{X}-1,120-122 \mathrm{~cm}$.

Radiolarians: few broken specimens in Sample 650A-20X-1, $120-122 \mathrm{~cm}$.

\section{Nonbiogenic Components of Sand Fractions}

Composition varies within grain size fractions as well as within the sequence from base to top. Clasts of silty sediments 
dominate in Samples 650A-20X-CC, 13-15 cm ( $>1000 \mu \mathrm{m})$ and $650 \mathrm{~A}-20 \mathrm{X}-1,133-135 \mathrm{~cm}$ (all fractions). Aggregates of relatively well sorted sand/silt sized grains occur in fractions $>500 \mu \mathrm{m}$ of Sample 650A-20X-1, 124-126 cm, whereas the finer fractions contain poorly sorted sediment aggregates which are frequently impregnated with pyrite.

Volcaniclastic material occurs in different size fractions. Shards of dark-colored, low-vesicular pumice and dark-colored opaque lapilli (both sometimes with pyrogenic minerals), as well as light-colored pumice with elongate vesicles occur in almost all samples with maximum grain sizes decreasing from base to top. Elongate glass shards dominate the fractions $<125 \mu \mathrm{m}$ of Sample 650A-20X-CC, $13-15 \mathrm{~cm}$.

Mica and undetermined mineral grains are frequent in fractions $<125 \mu \mathrm{m}$ of Samples $650 \mathrm{~A}-20 \mathrm{X}-1,124-126 \mathrm{~cm}$, and $650 \mathrm{~A}-$ 20X-1, 120-122 cm.

Few fragments of undetermined metamorphic rocks occur in Samples 650A-20X-CC, 13-15 cm; 650A-20X-1, 133-135 cm; and $650 \mathrm{~A}-20 \mathrm{X}-1,116-118 \mathrm{~cm}$.

The composition of Sample 650A-20X-CC, 9-13 cm (taken for foraminiferal studies, G. Glaçon), is similar to that of $650 \mathrm{~A}$ 20X-CC, $13-15 \mathrm{~cm}$.

\section{Sedimentological Interpretation}

There is no doubt that the well sampled interval (650A-20X-1, $135 \mathrm{~cm}$, to top) belongs to a turbidite (normal gradation, upcore-increasing carbonate content, benthic foraminifers, plant remains, metamorphic rocks). Its base is not yet fixed. It is likely that the sediments of Sections $650 \mathrm{~A}-20 \mathrm{X}-2$ and $650 \mathrm{~A}-$ $20 \mathrm{X}-\mathrm{CC}$ belong to the same turbiditic event, since they seem to be similarly composed (metamorphic rock fragments) as those of the studied layer.

\section{Stratigraphic Hypothesis}

Overlying sediments: no useful information.

The layer itself: the top samples $(650 \mathrm{~A}-20 \mathrm{X}-1,67-72 \mathrm{~cm})$ represent temperate environment.

Underlying sediments: Sample $650 \mathrm{~A}-21 \mathrm{X}-1,40-44 \mathrm{~cm}$, is taken from the upper part of a turbidite. Its foraminiferal assemblage is characterized by the occurrence of some warm species as Globigerinoides sacculifer, Globigerina ruber, and G. quadrilobatus. They should be reworked from a warm stage, perhaps isotope Stage 9.

Result: According to the stratigraphic interpretation of the warm species in the underlying sediment, the studied layer should be younger than isotope Stage 9 .

\section{Layer 12 (Core 22, Section 1, 12-70 cm)}

In Layer 12 (thickness: $0.58 \mathrm{~m}$ (true thickness unknown); depth below seafloor: $199.32-199.90 \mathrm{~m}$ ), the lower contact is presumably sharp (drilling disturbance), and the upper contact unknown. Structures in the lower, silty part of the layer cannot be ascertained because of drilling disturbances. The upper part is slightly laminated to structureless.

\section{General Textural Data}

Grain size distribution and contents of organic carbon and total carbonate are presented on Figure 14.

Grain size distribution shows a normally-graded sequence. The maximum sand content is $20 \%$ at the base. Slight cementation has produced sediment "clasts" which obviously did not exist during deposition of the layer. Scanning Electron Microscope (SEM) studies of such cemented sediments show that the average grain size of their components decreases upward. Therefore, we should not take the grain size curves as fact, but only as indications of tendencies. The real grain sizes are considered to be finer than measured.

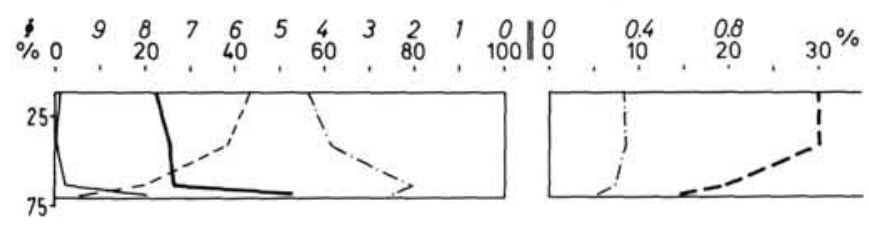

Figure 14. Sedimentological parameters for Core 650A-22X, Section 1, $12-70 \mathrm{~cm}$. See Figure 2 for legend.

Organic carbon and total carbonate contents show very similar relations: increase in the basal part (minimum $0.22 \%$ and $15 \%$ respectively) and stable contents in the upper part (around $0.33 \%$ and $30 \%$ respectively).

Clay mineralogy: illite and irregular mixed layer minerals; kaolinite dominates chlorite.

\section{Biogenic Components}

Only planktonic foraminifers occur. They are generally rare, badly preserved, and give no useful information. The top sample $(650 \mathrm{~A}-22 \mathrm{X}-1,12-14 \mathrm{~cm})$ is barren.

\section{Nonbiogenic Components of Sand Fractions}

Most components of the fractions owe their existence only to partial cementation of the studied deposit. However, as SEM photos show, in the lithified sediments, volcanic glass shards occur which are larger than $63 \mu \mathrm{m}$. Mica is a true component of the sand fractions.

\section{Sedimentological Interpretation}

Normal gradation and upcore-increasing carbonate contents characterize this layer as turbidite.

\section{Stratigraphic Hypothesis}

Because of lack of useful information, we have made no interpretation.

\section{Layer 13 (Core 24, Section 2, 12-89 cm)}

This core interval (thickness: $0.77 \mathrm{~m}$; depth below seafloor: $220.22-220.99 \mathrm{~m}$ ) is partly broken or in otherwise disturbed. Therefore, its condition renders structural observations more difficult. A few centimeters at the very base are laminated. The greatest part of the layer shows only diffuse color changes of low intensity. The sampling in the deeper part is insufficient.

\section{General Textural Data}

Grain size distribution and contents of organic carbon and total carbonate are shown in Figure 15.

Grain size distribution shows unclear relations (rather inversely-graded than normally-graded sequence). A sample (650A$24 \mathrm{X}-2,91-93 \mathrm{~cm}$ ) taken from the top of the underlying structureless layer contains few slightly cemented silty sandstones and sandy siltstones. They obviously belong to the laminated base of the studied layer which has been laterally caught by the

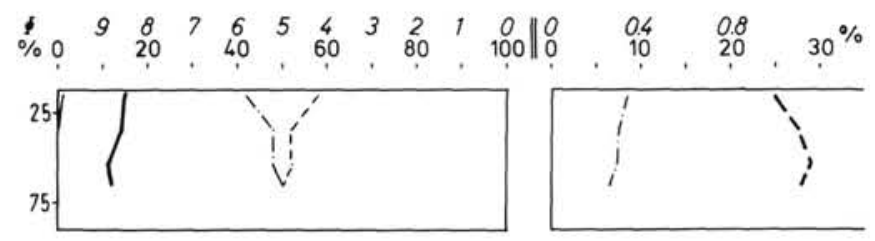

Figure 15. Sedimentological parameters for Core 650A-24X, Section 2, $12-89 \mathrm{~cm}$. See Figure 2 for legend. 
sample. Material from this laminated interval is no longer available (it was sampled for geochemical studies).

Organic carbon: steady increase upward from $0.26 \%$ to $0.34 \%$.

Total carbonate: nearly steady decrease upward from $28 \%$ to $25 \%$

Clay mineralogy: illite and irregular mixed layer minerals; kaolinite dominates chlorite.

\section{Biogenic content}

Benthic foraminifers: few undetermined specimens in Sample $650 \mathrm{~A}-24 \mathrm{X}-2,91-93 \mathrm{~cm}$. Occurrence in the laminated base of the layer is uncertain.

Planktonic foraminifers: Samples $650 \mathrm{~A}-24 \mathrm{X}-2,64-66 \mathrm{~cm}$, and $650 \mathrm{~A}-24 \mathrm{X}-2,52-54 \mathrm{~cm}$, are barren. The sand fraction of Sample $650 \mathrm{~A}-24 \mathrm{X}-2,36-40 \mathrm{~cm}$, consists almost completely of planktonic foraminifers indicating quite a normal sedimentation. The assemblage includes: dominant Globigerina quinqueloba, abundant $G$. bulloides, common Globorotalia scitula, few G. inflata, Globigerina falconensis, and Neogloboquadrina dutertrei, rare Globigerinella siphonifera, Globigerina cariacoensis, and Orbulina universa (some larger than $500 \mu \mathrm{m}$ ). Sample $650 \mathrm{~A}-24 \mathrm{X}-2,33-35 \mathrm{~cm}$, is very poor in planktonic foraminifers. Sample 650A-24X-2, 15-17 cm, shows a good assemblage similar to $650 \mathrm{~A}-24 \mathrm{X}-2,26-40 \mathrm{~cm}$, however, the number of Orbulina universa increased and few Bella praedigitata occur.

\section{Nonbiogenic Components of Sand Fractions}

Detail data for the base of this layer are not available (see above). Beside planktonic foraminifers, only few mineral grains occur in the top sample $(650 \mathrm{~A}-24 \mathrm{X}-2,15-17 \mathrm{~cm})$.

\section{Sedimentological Interpretation}

The data are insufficient for a good interpretation.

\section{Stratigraphic Hypothesis}

Overlying sediment: Samples $650 \mathrm{~A}-24 \mathrm{X}-1,33-37 \mathrm{~cm}$, and $650 \mathrm{~A}-24 \mathrm{X}-1,105-109 \mathrm{~cm}$, show assemblages very similar to those of the studied layer itself.

The layer itself is conspicuous, in that the assemblages considered to represent a normal sedimentation do not comprise species of the genus Globigerinoides (which normally occur in warm and temperate environments).

Underlying sediments: Sample 650A-24X-2, 92-96 cm (immediately below the studied layer), contains a mixture without any diagnostic value.

Result: The planktonic foraminiferal assemblages from the studied layer and the overlying sediments indicate a cold environment. This climatic interval is interpreted as most likely isotope Stage 10.

\section{Layer 14 (Core 25, Section 1, $120 \mathrm{~cm}$, to Section 25, CC)}

The whole core (thickness: $2.10 \mathrm{~m}$; depth below seafloor: $229.40-231.50 \mathrm{~m}$ ) shows beginnings of drilling biscuits. Therefore, fine-scaled structures cannot be observed. Core photos show differences in cohesion, which could indicate structural as well as textural inhomogeneities.

\section{General Textural Data}

Grain size distribution and contents of organic carbon and total carbonate are shown on Figure 16.

Grain size distribution: Single grains of sand size are obviously contaminations. Mean size (sensu Folk) suggests two separate normally-graded sequences.

Organic carbon: Highest content $(0.42 \%)$ is in base sample (650A-25X-CC, $18-20 \mathrm{~cm})$, decreases to $0.22 \%$, and then steady increases to $0.29 \%$.

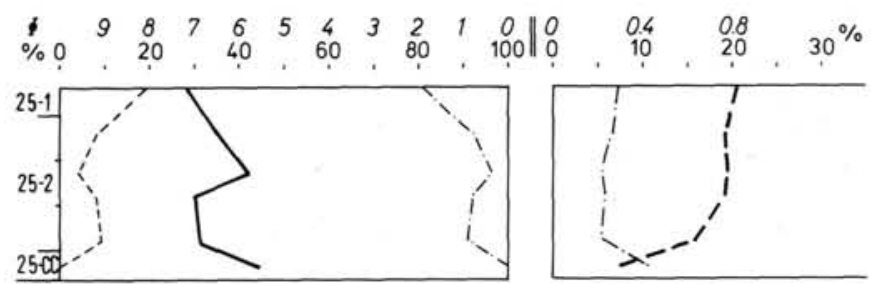

Figure 16. Sedimentological parameters for Core 650A-25X, Sections 1, $120 \mathrm{~cm}$ to CC. See Figure 2 for legend.

Total carbonate: lowest content $(8 \%)$ in base sample, rapid increase to $16 \%$, and then steady increase to $20 \%$. Carbonate content does not support the suggestion of two separate graded sequences.

Clay mineralogy: illite and irregular mixed layer minerals; kaolinite dominates chlorite.

\section{Biogenic Components}

Planktonic foraminifers: In $650 \mathrm{~A}-25 \mathrm{X}-\mathrm{CC}$, as in the whole studied layer, planktonic foraminifers are rare. In the part of the core catcher washed onboard we found rare Globigerinoides ruber, Globorotalia inflata, G. scitula, and Globigerina bulloides. In Samples 650A-25X-CC, 18-20 cm, and 650A-25X-2, 140-142 $\mathrm{cm}$, only small (less than $88 \mu \mathrm{m}$ ) individuals (Globigerina quinqueloba with few juvenile forms) occur. Samples 650A-25X-2, $92-96 \mathrm{~cm}$, and $650 \mathrm{~A}-25 \mathrm{X}-2,35-39 \mathrm{~cm}$, are barren. In Samples $650 \mathrm{~A}-25 \mathrm{X}-2,20-22 \mathrm{~cm}$, and $650 \mathrm{~A}-25 \mathrm{X}-1,120-122 \mathrm{~cm}$, very rare small individuals occur again (Globigerina bulloides and $G$. quinqueloba). Therefore, the hypothesis of two separate turbidites within the studied layer is supported.

\section{Sedimentological Interpretation}

The data are not yet sufficient for a definite interpretation. There exist obviously two separate turbidites of fine grain size spectra.

\section{Stratigraphic Hypothesis}

There are no arguments for a stratigraphic interpretation.

\section{Layer 15 (Core 26, Section 1, $43 \mathrm{~cm}$, to Section 26, CC)}

The whole core (thickness: $5.64 \mathrm{~m}$; depth below seafloor: 238.23-243.87 m) shows beginnings of drilling biscuits. Therefore, structural information cannot be obtained with certainty. Some parts of this layer seem to be structureless.

\section{General Textural Data}

Grain size distribution and contents of organic carbon and total carbonate are presented on Figure 17.

Grain size distribution: The curves show no definite tendencies. It is true that sand content is highest in the deeper part and decreases upward. However, mean size (sensu Folk) decreases upcore only very slightly.

Organic carbon and total carbonate: Both are nearly constant at very low levels (organic carbon around $0.1 \%$, total carbonate between $2 \%$ and $5 \%$ ):

Carbonate mineralogy: The only carbonate mineral is calcite; its $\mathrm{MgCO}_{3}$ content varies between $1.5 \%$ and $5 \%$ with a maximum around $2 \%$.

Bulk mineralogy: In most samples only quartz and calcite could be identified; in some samples feldspars are slightly indicated.

Clay mineralogy: The assemblage is nearly stable over the whole layer; it consists only of illite $(80 \%-85 \%)$ and $7 \AA$ miner- 


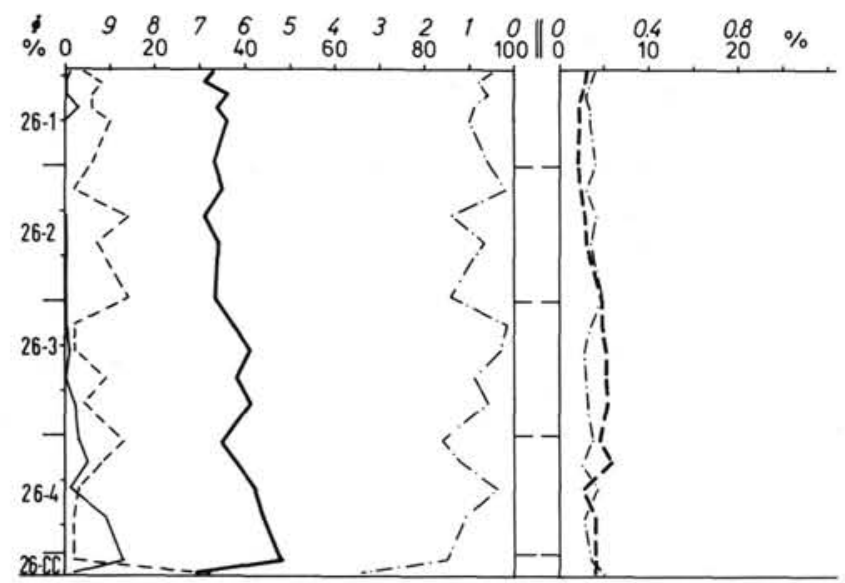

Figure 17. Sedimentological parameters for Core 650A-26X, Sections 1, $43 \mathrm{~cm}$ to CC. See Figure 2 for legend.

als $(15 \%-20 \%)$. The latter are almost totally represented by chlorite; there are only traces of kaolinite.

\section{Biogenic Components}

They are generally not frequent.

Planktonic foraminifers: In Sample 650A-26X-CC washed onboard, only few Globigerina quinqueloba and rare Globorotalia scitula occur. Samples between 650A-26X-CC, 19-21 cm, and $650 \mathrm{~A}-26 \mathrm{X}-2,144-146 \mathrm{~cm}$, are barren. In Sample 650A$26 \mathrm{X}-2,131-135 \mathrm{~cm}$, we found rare Globigerina quinqueloba (smaller than $125 \mu \mathrm{m}$ ) and rare Globorotalia inflata (larger than $200 \mu \mathrm{m}$ ). Samples between $650 \mathrm{~A}-26 \mathrm{X}-2,84-86 \mathrm{~cm}$, and $650 \mathrm{~A}-$ $26 \mathrm{X}-1,99-101 \mathrm{~cm}$, are barren. Again in $650 \mathrm{~A}-26 \mathrm{X}-1,84-86 \mathrm{~cm}$, rare Globorotalia inflata and Globigerina bulloides, and in Sample $650 \mathrm{~A}-26 \mathrm{X}-1,46-50 \mathrm{~cm}$, a Globorotalia scitula occur. Samples $650 \mathrm{~A}-26 \mathrm{X}-1,69-71 \mathrm{~cm}$, to $650 \mathrm{~A}-26 \mathrm{X}-1,45-47 \mathrm{~cm}$, are barren.

Nannoplankton: Autochthonous and reworked species in almost all samples but always in small amounts.

Porifera: few silicious sponge spicules in Sample 650A-26X-1, $84-86 \mathrm{~cm}$.

\section{Nonbiogenic Components of Sand Fraction}

From base to Sample $650 \mathrm{~A}-26 \mathrm{X}-2,84-86 \mathrm{~cm}$, the sand fraction consists nearly totally of shards of colorless elongate pumice or glass. Above this level volcaniclastic particles show a broad spectrum, however, their frequency is low. The particles consist of colorless elongate pumice, brownish pumice with globular vesicles, and dark-colored opaque lapilli. Mineral grains are generally rare.

\section{Sedimentological Interpretation}

The slight normal gradation suggests an interpretation as turbidite. Perhaps the sediments represent material which has been repeatedly reworked and displaced, and which has lost its coarser-grained portion.

\section{Stratigraphic Hypothesis}

There are no arguments for a stratigraphic interpretation.

\section{Layer 16 (Core 27, Section 1, $70 \mathrm{~cm}$, to Section 27, CC)}

The whole core (thickness: $6.10 \mathrm{~m}$; depth below seafloor: $248.20-254.30 \mathrm{~m}$ ) is influenced by drilling disturbances producing biscuits. Having regard to this fact, the layer seems to be nearly structureless.

\section{General Textural Data}

Grain size distribution and contents of organic carbon and total carbonate are presented on Figure 18.

Grain size distribution: Sand content exceeds $1 \%$ only in two samples (650A-27X-1, 120-122 cm, and 650A-27X-3, 89-91 cm). Silt and clay vary in wide ranges (maximum amplitude $45 \%$ ): The oscillations of the curves do not only indicate normallygraded sequences but also inversely-graded ones. Grain size distribution figured by silt/clay ratios is generally confirmed by the curve of "mean size" sensu Folk.

Organic carbon: Values are around $0.15 \%$ without distinct variations.

Total carbonate: Generally low (between $8 \%$ and $15 \%$ ). The curve of this parameter, however, easily shows variations which could be interpreted as cyclicity. Carbonate content increases in the lower part of the layer and is more or less constant in the middle and upper parts. Interruptions are documented only in Samples 650A-27X-3, 89-91 cm, 650A-27X-2, 28-30 cm, 650A$27 \mathrm{X}-1,120-122 \mathrm{~cm}$, and $650 \mathrm{~A}-27 \mathrm{X}-1,89-91 \mathrm{~cm}$, where the carbonate content is distinctly lower. These low carbonate values always correlate with maxima of silt as well as mean size curves. However, this rule cannot be reversed; some other maxima of these parameters are characterized by "high" carbonate contents.

Carbonate mineralogy: Calcite is the only identified carbonate mineral. Its $\mathrm{MgCO}_{3}$ content varies between $1.5 \%$ and $2.8 \%$.

Bulk mineralogy: The $\mathrm{x}$-ray diffractometer records show generally low intensities. Quartz and calcite dominate and feldspars are always identified.

Clay mineralogy: illite and irregular mixed layer minerals; kaolinite dominates chlorite.

\section{Biogenic Content}

Planktonic foraminifers are the only biogenic components of the sand fractions. In Sample 650A-27X-CC washed onboard, we found rare Globigerina bulloides, G. quinqueloba, and Globorotalia inflata. All other 39 samples are barren.

Nannoplankton: Autochthonous specimens are common to abundant in almost all samples. Reworked specimens are common in almost all samples but the number decreases at the top of the interval.

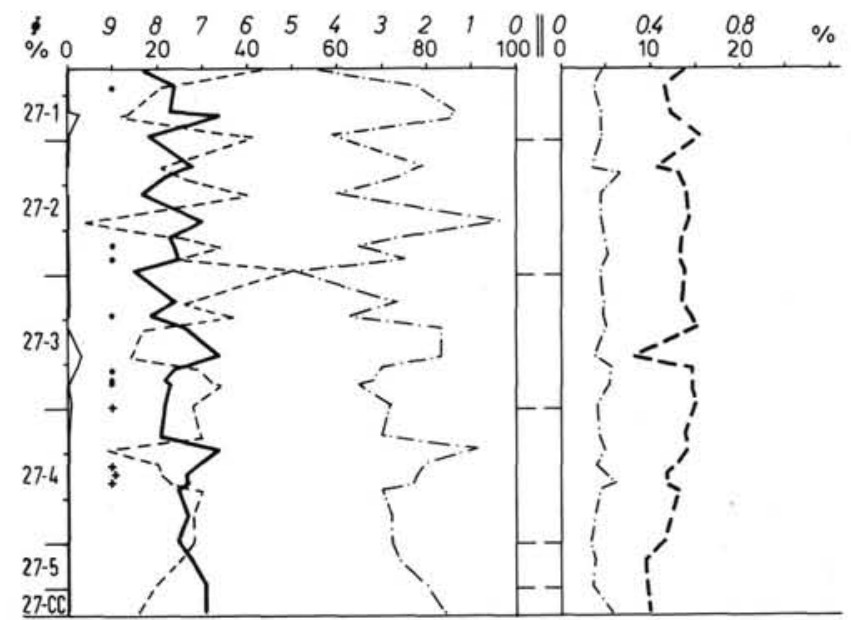

Figure 18. Sedimentological parameters for Core 650A-27X, Sections 1, $70 \mathrm{~cm}$ to $\mathrm{CC}$. Occurrences of aggregates (dots) and pyrite-cemented particles (crosses) are indicated. 


\section{Nonbiogenic Components of Sand Fractions}

Colorless volcanic glass is the most frequent component; in most cases it dominates the fractions $<125 \mu \mathrm{m}$. However, in some samples, the dominating components are aggregates of very fine-grained glass or even pyrite-impregnated sediments.

\section{Sedimentological Interpretation}

Aggregates occur only within relatively fine-grained sediments, never in relatively coarse-grained ones (see Fig. 18). We can conclude that relatively fine-grained deposits preferably tend to become cemented. From the occurrence of aggregates within the finest sand fractions, we can also conclude that aggregates occur in silt size fractions, too. This again means that we have to consider a secondary shift of the grain size spectrum toward the coarser side. As is indicated on Figure 18, the occurrence of the aggregates correlates with reversely-graded intervals.

From these observations and considerations, we can conclude that the reversely-graded intervals were most probably the finest-grained upper parts of normally-graded sequences.

The observations from sand composition, SEM photos, and $\mathrm{x}$-ray diffractometry lead to the conclusion that volcanic glass is the overwhelming component of this studied layer. This glass has obviously a small variation spectrum (maximum diameter of shards about $125 \mu \mathrm{m}$, colorless, platy to cuspate) in contrast to most of the other described layers (e.g., the thick turbidite of Layer 9).

Thus, we can interpret the studied layer as a sequence of at least seven individual normally-graded intervals. Their origin can be explained in different ways: (1) they can be turbidites which consist of relatively pure colorless glass shards primarily deposited by a volcanic event, (2) they can be turbidites the material of which has been repeatedly reworked. Thus, possible original pumice may have been more and more decomposed and matured, and (3) they can be true ash-fall layers from volcanic eruptions which immediately succeeded one another.

Since the maximum grain size of the glass shards is relatively small (about $125 \mu \mathrm{m}$ ) in all of the normally-graded sequences, and potential source volcanoes are not very far from the deposition site, it seems to be more likely that the deposits originated from turbidite processes. The latter could cause such a constant maximum grain size much earlier in a sequence of deposits than could be expected from succeeding volcanic eruptions which must have had exactly the same intensities. Moreover, the relatively high content of nannoplankton (observed in SEM photographs) contradicts the ash-fall hypothesis.

\section{Stratigraphic Hypothesis}

There are no arguments for a stratigraphic interpretation.

\section{Layer 17 (Core 29, Section 1, $22 \mathrm{~cm}$ to Section 29, CC)}

Because of drilling disturbances, detail structures in this layer (thickness: $3.28 \mathrm{~m}$; depth below seafloor: $267.02-270.30 \mathrm{~m}$ ) cannot be observed. These rather homogenous sediments look similar to those of Core 650A-27X (Layer 16). The sediments of the deepest parts (650A-29X-CC) tend to disintegrate into friable fragments.

\section{General Textural Data}

Grain size distribution and contents of organic carbon and total carbonate see on Figure 19.

Grain size distribution: The space between the samples is wider than in Core $650 \mathrm{~A}-27 \mathrm{X}$. Sand content never exceeds $0.2 \%$. The curves show a general grain size decrease upcore.

Organic carbon and total carbonate: Both are nearly constant at low levels (organic carbon around $0.15 \%$ and total carbonate between $7 \%$ and $9 \%$ with increasing tendency upcore.)

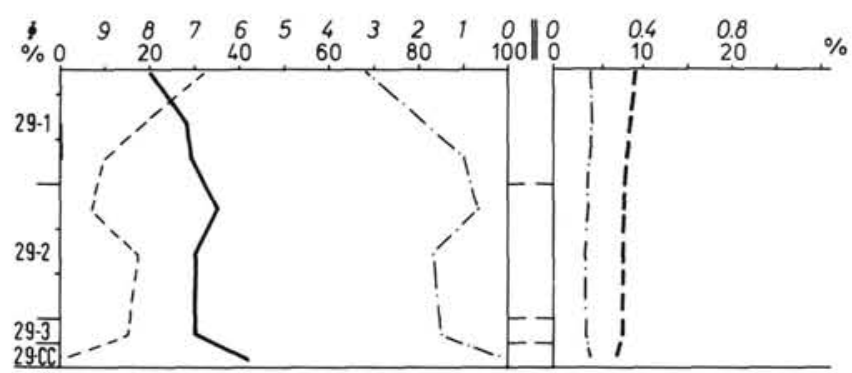

Figure 19. Sedimentological parameters for Core 650A-29X, Sections 1, $22 \mathrm{~cm}$ to CC. See Figure 2 for legend.

Carbonate mineralogy: Calcite is the only identified carbonate mineral; its $\mathrm{MgCO}_{3}$ content varies between $2.0 \%$ and $2.5 \%$.

Bulk mineralogy: The x-ray diffractometer records show generally low intensities. Quartz and calcite dominate; feldspars are always identified. The results are identical with those of Core 650A-27X (Layer 16).

\section{Biogenic Content}

Planktonic foraminifers: In Sample 650A-29X-CC (washed onboard), very rare Globigerina quinqueloba and a Globorotalia oscitans have been found. Rare Globorotalia inflata occur in 650A-29X-1, 30-34 cm. All other samples are barren.

Nannoplankton: Autochthonous specimens are common in all samples with upward-increasing tendency, whereas the frequency of reworked ones decreases upcore.

\section{Nonbiogenic Components of Sand Fractions}

True sand-sized components occur only in the base sample (650A-29X-CC, 15-17 cm). It consists totally of colorless volcanic glass. Few aggregates of obviously secondary origin have been found in Sample 650A-29X-1, 81-83 cm.

\section{Sedimentological Interpretation}

The textural data are not so extensive as for Core $650 \mathrm{~A}-27 \mathrm{X}$ sediments (Layer 16), but suggest a sediment type very similar to that of Core 650A-27X. However, in case of Core 650A-29X, the studied "homogenous/structureless" interval seems to be the upper part of a much thicker normally-graded sequence (note the incomplete recovery of Core 650A-29X and the zero recovery of Core $650 \mathrm{~A}-30 \mathrm{X}$ ).

The extreme interpretation of Cores $650 \mathrm{~A}-29 \mathrm{X}$ and $650 \mathrm{~A}-30 \mathrm{X}$ gives an about 19.5 -m-thick turbidite layer, the coarse-grained base of which has been washed out (analogy with Cores 650A$11 \mathrm{H}$ through $650 \mathrm{~A}-14 \mathrm{X}$, Layer 9).

\section{Stratigraphic Interpretation}

There are no arguments for stratigraphic interpretation.

\section{Layer 18 (Core 31, Section 2, $74 \mathrm{~cm}$, to Section 31, CC)}

The whole core (thickness: $4.08 \mathrm{~m}$; depth below seafloor: $288.44-292.52 \mathrm{~m}$ ) is affected by drilling disturbances. The studied interval includes sediments which appear to be normally graded, as well as the basal part of a superposed layer.

\section{General Textural Data}

Grain size distribution and contents of organic carbon and total carbonate are presented on Figure 20.

Grain size distribution: The curves show intensive variations. They have no value for the original sedimentary grain size distribution since fragments of secondarily cemented sediment always occur. 


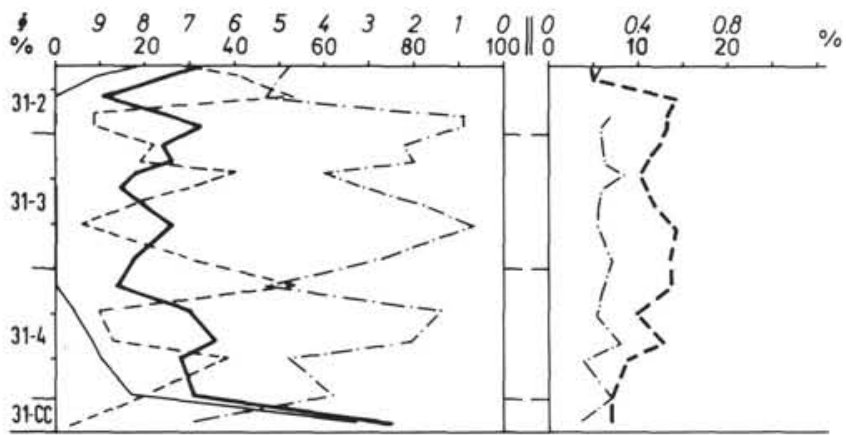

Figure 20. Sedimentological parameters for Core 650A-31X, Sections 2, $74 \mathrm{~cm}$ to $\mathrm{CC}$. See Figure 2 for legend.

Organic carbon and total carbonate: Both curves oscillate at low levels (organic carbon around 0:25\% and total carbonate between $7 \%$ and $14 \%$ ). They show no clear correlation to each other. The most obvious result from the carbonate curve is the observation that the lowermost contents occur in those sediments we considered to be the bases of normally graded sequences.

Carbonate mineralogy: Calcite is the only identified carbonate mineral; its $\mathrm{MgCO}_{3}$ content varies between $1.25 \%$ and $2.75 \%$.

Bulk mineralogy: Beside quartz, feldspar, and calcite, there occur phillipsite and analcime.

Clay mineralogy: The assemblage is very constant; illite $84 \%$ $88 \%, 7 \AA$ minerals (almost completely represented by chlorite) $12 \%-16 \%$, and smectite is not found.

\section{Biogenic Content}

Benthic foraminifers: Sample 650A-31X-2, 74-76 cm, contains 14 broken specimens (see Table 1). The mode of bathymetric distribution is located in epibathyal depths (zones 3 and 4; Fig. 3).

Planktonic foraminifers: In Sample 650A-31X-CC (washed onboard), we found abundant Globorotalia inflata, common dextral Neogloboquadrina pachyderma, Globigerina bulloides, G. quinqueloba, and Orbulina universa, rare Globorotalia truncatulinoides excelsa, G. scitula, and Globigerinoides ruber. In Sample 650A-31X-CC, $25-27 \mathrm{~cm}$, the same assemblage without Globorotalia truncatulinoides excelsa occurs, however, less frequent. Sample 650A-31X-4, 139-141 cm, contains only few Globigerina quinqueloba and a dextral Globorotalia scitula. In Sample $650 \mathrm{~A}-31 \mathrm{X}-4,99-101 \mathrm{~cm}$, there occur planktonic foraminifers only in size fractions between 88 and $177 \mu \mathrm{m}$ (common Globigerina quinqueloba, few dextral Neogloboquadrina pachyderma, Globigerinita glutinata, Globigerinoides cyclostomus, and rare Globorotalia inflata. All samples between $650 \mathrm{~A}-31 \mathrm{X}-4$, $79-81 \mathrm{~cm}$, and $650 \mathrm{~A}-31 \mathrm{X}-2,92-96 \mathrm{~cm}$, are barren. The topmost sample (650A-31X-2, 85-87 cm) contains Globigerina quinqueloba very rarely as free specimens, but sometimes identified within the cemented sediment.

Nannoplankton: Autochthonous specimens occur from Sample $650 \mathrm{~A}-31 \mathrm{X}-3,77-79 \mathrm{~cm}$, to top. Reworked specimens are rare within all samples.

\section{Nonbiogenic Components of the Sand Fraction}

Apart from few planktonic foraminifers, the sand fraction consists of fragments of cemented sediment and a small portion of undetermined mineral grains.

\section{Observations from SEM photographs}

Phillipsite is a very common constituent of the sediment. Platy minerals looking like clinoptilolite have been found concentrated in clusters. However, the occurrence of this mineral is not proved by x-ray diffractometry. Analcime, which is clearly identified in the $\mathrm{x}$-ray records, has not been observed in SEM photographs.

\section{Sedimentological Interpretation}

Since grain size distribution cannot be used to recognize the original sediment, we have rather to speculate than to interpret. From the carbonate content curve, we can assume that the studied interval comprises in fact (1) a normally-graded sequence (carbonate content generally increasing upcore) which means turbidite, and (2) the base of the superposed turbidite. This speculation is supported by the occurrence of relatively shallow water benthic foraminifers in the uppermost sample.

The sediments seem to be cemented by phillipsite (and analcime) developing from volcanic glass which obviously totally disappeared.

\section{Stratigraphic Hypothesis}

No arguments are given for an interpretation.

\section{Layer 19 (Core 38, Section 1, 40-73 cm)}

At the base of the studied layer (thickness: $0.33 \mathrm{~m}$; depth below seafloor: $354.30-354.63 \mathrm{~m}$ ) there is a sharply bounded dark interval. On top of it, the color develops from darker to lighter. Structures cannot be observed (partially disturbed core). The upper boundary is diffuse (structurally as well as color).

\section{General Textural Data}

Grain size distribution and contents of organic carbon and total carbonate are presented on Figure 21.

Grain size distribution: The curves do not present the real relations for two reasons: (1) The samples were requested in 1-cm intervals, but the actually sampled intervals ( $2 \mathrm{~cm}$ thickness) are too wide to document individual layers. Moreover, parts of the cores are often shifted within the liner after intensive sampling on board the ship. Then, a millimeter-precise sampling in the core repository is meaningful only when the core photographs are used to readjust the core length scale. Thus, we have to assume that the thin dark layer at the base has been caught in both Samples 650A-38X-1, 73-75 cm, and 650A-38X-1, 71-73 $\mathrm{cm}$. (2) Sample 650A-38X-1, 71-73 cm, contains a distinct portion of fragments of cemented sediment which shifts the grain size spectrum toward the coarse side.

Nevertheless, with regard to the insufficiencies and problems mentioned above, a normally-graded sequence is documented. The increase of sand content in the upper part is caused by an increasing amount of planktonic foraminifers (increasing normalization of sedimentation). The lowermost sample (650A$38 \mathrm{X}-1,73-75 \mathrm{~cm}$ ) represents generally the top of the underlying deposit (apart from the possible contamination with material from the dark layer).

Organic carbon: The curve shows decreasing content in the lower part and increasing content in the upper one.

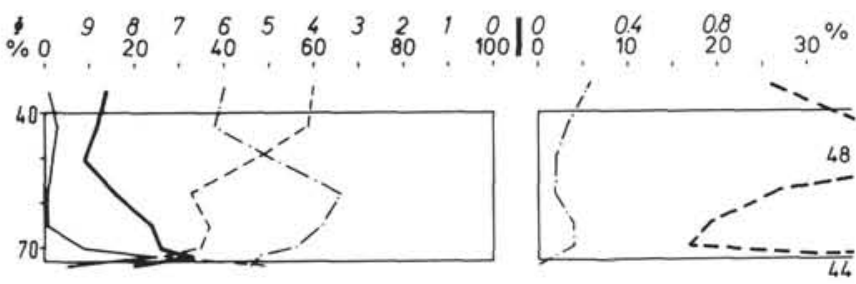

Figure 21. Sedimentological parameters for Core 650A-38X, Section 1, $40-73 \mathrm{~cm}$. See Figure 2 for legend. 
Total carbonate: The understanding of the lower part of the curve is difficult. The lowest carbonate value is recorded from Sample $650 \mathrm{~A}-38 \mathrm{X}-1,69-71 \mathrm{~cm}$, which is very likely situated above the dark-colored base of the studied layer. The underlying Sample $650 \mathrm{~A}-38 \mathrm{X}-1,71-73 \mathrm{~cm}$, which is considered to include the dark basal interval and which contains fragments of cemented sediments is astonishingly rich in carbonate.

From the lowest carbonate value in Sample 650A-38X-1, 69$71 \mathrm{~cm}$, the content increases steadily upcore and oscillates in the upper part at a level which is unusually high compared with those known from all layers described above (more than 40\%).

Carbonate mineralogy: Calcite is the only identified carbonate mineral; its $\mathrm{MgCO}_{3}$ content varies between $1.5 \%$ and $3 \%$.

Bulk mineralogy: Quartz and calcite are components in all samples. The frequency of the other components varies as follows: Feldspar occurs in all samples except the two uppermost ones (650A-38X-1, 49-51 cm, and 650A-38X-1, 42-44 cm). Analcime is present in the two deepest samples (650A-38X-1, $73-75 \mathrm{~cm}$, and $650 \mathrm{~A}-38 \mathrm{X}-1,71-73 \mathrm{~cm}$ ). Phillipsite occurs in Samples 650A-38X-1, 71-73 cm, and 650A-38X-1, 69-71 cm. These observations indicate an impoverishment of the mineral assemblages upcore; first, the zeolites disappear, then the feldspars.

Clay mineralogy: Only one analysis is available (Sample 650A$38 \mathrm{X}-1,71-73 \mathrm{~cm}$ ): illite $93 \%, 7 \AA$ minerals (dominated by chlorite) $7 \%$.

\section{Biogenic Content}

Fish remains occur in Samples 650A-38X-1, 49-51 cm, and $650 \mathrm{~A}-38 \mathrm{X}-1,42-44 \mathrm{~cm}$.

Benthic foraminifers: One or two broken specimens in Samples $650 \mathrm{~A}-38 \mathrm{X}-1,73-75 \mathrm{~cm}, 650 \mathrm{~A}-38 \mathrm{X}-1,71-73 \mathrm{~cm}$, and $650 \mathrm{~A}-$ $38 \mathrm{X}-1,69-71 \mathrm{~cm}$ (Table 1). All indicate the deepest bathymetric zone (lower mesobathyal).

Planktonic foraminifers: With regard to the insufficiencies of sampling as mentioned before, the assemblage of the base sample (650A-38X-1, 71-73 cm) cannot be clearly interpreted. It is characterized by abundant sinistral Globorotalia truncatulinoides excelsa (some larger than $500 \mu \mathrm{m}$ ), common Globigerinoides elongatus, rare Neogloboquadrina dutertrei, Globorotalia inflata (smaller than $354 \mu \mathrm{m}$ ), some Orbulina universa and Globigerina bulloides. In size fractions less than $180 \mu \mathrm{m}$, there occur very abundant Globigerina quinqueloba, some Globigerinita glutinata, and dextral Neogloboquadrina pachyderma.

The assemblage of Sample $650 \mathrm{~A}-38 \mathrm{X}-1,69-71 \mathrm{~cm}$, is totally different from the previous one. It is characterized by abundant Globigerina bulloides in fraction 250-354 $\mu \mathrm{m}$ and few rare dextral Neogloboquadrina pachyderma in smaller fractions.

Sample 650A-38X-1, 64-66 cm, contains fragments of planktonic foraminifers. In $650 \mathrm{~A}-38 \mathrm{X}-1,57-59 \mathrm{~cm}$, an assemblage similar to $650 \mathrm{~A}-38 \mathrm{X}-1,69-71 \mathrm{~cm}$, occurs. This sample and the following ones $(650 \mathrm{~A}-38 \mathrm{X}-1,49-51 \mathrm{~cm}$, and $650 \mathrm{~A}-38 \mathrm{X}-1,42-44$ $\mathrm{cm})$ represent a normal sediment characterized by the high carbonate content mentioned above. The composition of these assemblages differ in following ways: $650 \mathrm{~A}-38 \mathrm{X}-1,57-59 \mathrm{~cm}$, is characterized by the predominance of Globigerina bulloides with rare dextral Neogloboquadrina pachyderma (cold). 650A-38X-1, $49-51 \mathrm{~cm}$, is more diversified by addition of abundant large dextral Globorotalia scitula, few $G$. inflata, and Globigerinoides ruber to the previous assemblage (temperate warm). Finally, in sample $650 \mathrm{~A}-38 \mathrm{X}-1,42-44 \mathrm{~cm}$, Globorotalia inflata becomes common, the number of $G$. scitula decreases drastically, and some Globigerinoides elongatus are present (temperate). This changing in composition of the assemblages reflects a warming toward the top.
Gastropods: internal molds in Samples 650A-38X-1, 71-73 $\mathrm{cm}$, and $650 \mathrm{~A}-38 \mathrm{X}-1,69-71 \mathrm{~cm}$.

Indefinite calcareous debris occurs in Samples 650A-38X-1, $73-75 \mathrm{~cm}, 650 \mathrm{~A}-38 \mathrm{X}-1,71-73 \mathrm{~cm}$, and $650 \mathrm{~A}-38 \mathrm{X}-1,69-71 \mathrm{~cm}$.

\section{Nonbiogenic Components of Sand Fraction}

Indefinite mineral grains and mica occur in Samples 650A$38 \mathrm{X}-1,73-75 \mathrm{~cm}, 650 \mathrm{~A}-38 \mathrm{X}-1,71-73 \mathrm{~cm}$, and $650 \mathrm{~A}-38 \mathrm{X}-1$, $69-71 \mathrm{~cm}$. Small fragments $(<125 \mu \mathrm{m})$ of gray, greenish and brownish shales and low-grade phyllites occur in Sample 650A$38 \mathrm{X}-1,71-73 \mathrm{~cm}$. It is very likely that they were originally components of very thin sandy layers which can be observed in cemented fragments. SEM photographs (Pl. 5, Figs. 1 and 2) give an impression of these sandy layers and the abrupt change in grain size (sharp basal contact?). The growth of a network of phillipsite crystals (Pl. 5, Fig. 3) seems to be responsible for the slight cementation of the sediments. Volcanic glass is not observed.

\section{Sedimentological Interpretation}

Although the grain size data do not completely reflect the depositional relations, evaluating the information from different types of components, we can identify this layer as a turbidite. It obviously started with an interval of fine lamination. The sandy laminae seem to contain relatively well sorted calcareous biogenic debris $(<125 \mu \mathrm{m})$, planktonic foraminifers (prevailing in fractions $125-354 \mu \mathrm{m}$ ), and fragments of shales and low-grade metamorphic rocks $(<125 \mu \mathrm{m})$. Their restriction to the finer size fractions points to a sorting which may have happened during former reworking processes (stepwise transportation by turbidity currents). The occurrence of these relatively well sorted components is obviously not restricted to the striking thin dark layer at $650 \mathrm{~A}-38 \mathrm{X}-1,73 \mathrm{~cm}$, but they occur also within some centimeters of the superposed sediment. The dark layer, however, may owe its existence to a concentration of the laminae mentioned.

In the upper part, the content of planktonic foraminifers (and nannoplankton?) increases distinctly. The sediment is richer in carbonate than we found in the studied layers of younger age.

\section{Stratigraphic Hypothesis}

Overlying sediments: (1) Sample 650A-36X-1, 33-37 cm, contains a rich planktonic foraminiferal assemblage. It indicates a relatively warm environment by the occurrence of some Globigerinoides ruber. (2) The boundary between nannoplankton zones NN19 and NN20 is situated in Core 650A-37X (Shipboard Scientific Party 1987, p. 151). This boundary defines this level as isotope Stage 12.

The layer itself: The upper part of the studied layer contains assemblages indicating a warming upward.

Underlying sediments: The assemblage of Sample 650A-38X-1, $92-96 \mathrm{~cm}$, is characterized by Globigerinoides ruber indicating warm environment.

Result: The planktonic foraminiferal assemblages of isotope Stages 11 and 13 are generally very similar. Starting from the boundary NN19/NN20 as a well-determined level, we have to consider the sediments of Core $650 \mathrm{~A}-37 \mathrm{X}$ as representing isotope Stage 12. Consequently, the sediments of the studied layer and that of the underlying Sample 650A38X-1, 92-96 cm (warm environment), should have been deposited in isotope Stage 13.

\section{Layer 20 (Core 42, Section 1, 0-25 cm)}

The dark-gray, sandy, and faintly laminated deposit (thickness: $0.25 \mathrm{~m}$; depth below seafloor: $392.40-392.65 \mathrm{~m}$ ) is under- 
lain by a light-colored sediment from which an additional sample $(650 \mathrm{~A}-42 \mathrm{X}-1,25-27 \mathrm{~cm})$ is studied for comparison.

\section{General Textural Data}

Grain size distribution and contents of organic carbon and total carbonate are presented on Figure 22.

The grain size data are without value since the sediments contain varying amounts of cemented lumps.

The total carbonate values indicate the nannofossil ooze character of the underlying deposit. The base sample (650A-42X-1, $23-25 \mathrm{~cm}$ ) of the dark-gray, sandy layer is relatively rich in carbonate, whereas the upper sample is practically free of carbonate.

Bulk mineralogy: Each of the three samples represents a special mineral assemblage: (1) The sample from the underlying nannofossil ooze contains quartz, calcite $\left(2.25 \% \mathrm{MgCO}_{3}\right)$, and traces of phillipsite. (2) The base sample of the dark-gray layer (comprising the sandstones) shows quartz, calcite $\left(2 \% \mathrm{MgCO}_{3}\right)$, and phillipsite. Occurrence of feldspar is uncertain. (3) The upper (greatest?) part of the dark-gray layer consists almost completely of phillipsite. There is only a tiny reflection at about $29.4^{\circ} 2 \theta$ indicating calcite.

\section{Biogenic Content}

Planktonic foraminifera: The base sample (650A-42X-1, 23$25 \mathrm{~cm}$ ) contains abundant Orbulina universa, Globorotalia inflata, common Globigerinoides elongatus, few G. ruber, G. quadrilobatus, and Globorotalia scitula. This assemblage is very similar to that of the immediately underlying Sample $650 \mathrm{~A}-42 \mathrm{X}-1$, $25-27 \mathrm{~cm}$, and looks as though it originated by remobilization of the underlying sediment. In the sample from the upper part $(650 \mathrm{~A}-42 \mathrm{X}-1,6-8 \mathrm{~cm})$ the finest sand fraction (less than $88 \mu \mathrm{m}$ ) is barren. In the other fractions, we found a distinct classification depending on the grain size: very rare Globigerina quinqueloba and Globorotalia scitula $(125-180 \mu \mathrm{m})$, common Globigerina quinqueloba with few dextral Neogloboquadrina pachyderma, rare Globigerinoides elongatus $(180-250 \mu \mathrm{m})$, some Globorotalia inflata (250-354 $\mu \mathrm{m})$, and some Orbulina universa (larger than $354 \mu \mathrm{m})$.

Nannoplankton: Autochthonous specimens are abundant in Sample 42X-1, 25-27 cm (underlying deposit), and frequent in Sample $42 X-1,23-25 \mathrm{~cm}$ (base of the dark-gray, sandy layer). The amount of reworked specimens is rather small.

The base sample contains lumps of white sandstones with $350 \mu \mathrm{m}$ maximum component size. The components are sharpedged colorless, grayish and greenish minerals and irregularly formed rock fragments(?) as well as planktonic foraminifers. Also a bryozoan fragment has been observed. Moreover, uncemented planktonic foraminifers occur. Lumps of yellowish finegrained sediments dominate in the finer grain size fractions.

The sand fraction of the upper sample consists completely of lumps of yellowish, fine-grained sediments.

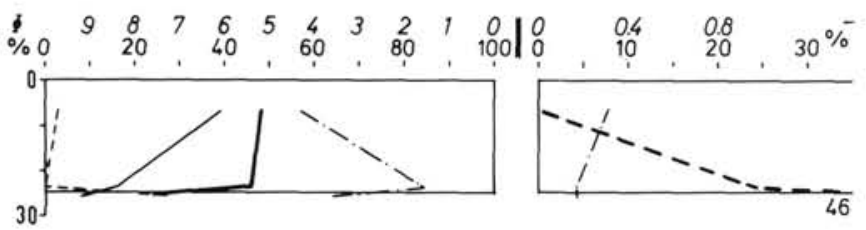

Figure 22. Sedimentological parameters for Core 650A-42X, Section 1, 0-25 cm. See Figure 2 for legend.

\section{Sedimentological Interpretation}

The occurrence of a practically pure zeolite layer (Pl. 5, Fig. 4) must be interpreted as an originally existing pure layer of volcanic glass. This, again, can be explained most easily as an ashfall deposit. The thin level of phillipsite-cemented sandstones below this ash-fall deposit should testify to a turbiditic event. It may have been triggered by a shaking caused by a volcanic eruption in the neighborhood, the ashes of which then superposed the turbidite layer.

\section{Stratigraphic Hypothesis}

Overlying sediments and the layer itself: no useful information.

Underlying sediments: The planktonic foraminiferal assemblage of Sample $650 \mathrm{~A}-42 \mathrm{X}-1,25-27 \mathrm{~cm}$, is very similar to that of $650 \mathrm{~A}-42 \mathrm{X}-1,23-25 \mathrm{~cm}$, but without dilution by nonbiogenic components. The climatic information is "temperate warm."

Result: A direct stratigraphic interpretation is not possible, however, see the stratigraphic discussion ("Discussion" section below, paragraph 13).

\section{Layer 21 (Core 42, Section 2, $30 \mathrm{~cm}$, to 42, CC)}

A macroscopically homogenous sediment (thickness: $0.84 \mathrm{~m}$; depth below seafloor: $393.87-394.71 \mathrm{~m}$ ) which is somewhat lithified. The core is broken in pieces of varying length.

\section{General Textural Data}

Grain size distribution and contents of organic carbon and total carbonate are on Figure 23.

The grain size data are most likely unusable. All samples contain phillipsite. Therefore we have to assume that the sediments are at least partially cemented. The only useful data are total carbonate values. They increase steadily upcore and signalize, with regard to the results from the studied layers of younger age, a turbidite sequence.

$\mathrm{X}$-ray diffractometry shows a mineral assemblage of quartz, calcite (about $2.5 \% \mathrm{MgCO}_{3}$ ), feldspar, and phillipsite.

\section{Biogenic Content}

Planktonic foraminifers: Sample 650A-42X-CC (washed onboard) contains common Globorotalia inflata and rare Globigerinoides ruber. $650 \mathrm{~A}-42 \mathrm{X}-\mathrm{CC}, 8-10 \mathrm{~cm}$, is barren. Globorotalia inflata occurs again rarely in Sample 650A-42X-2, 92-96 $\mathrm{cm}$. The samples following upcore are barren again.

Nannoplankton: The assemblages are characterized by reworked specimens (common in all samples). Autochthonous specimens are common only in the uppermost sample, but rather rare in the others.

\section{Sedimentological Interpretation}

The layer seems to be part of the "homogenous" upper interval of a turbidite (note the incomplete recovery).

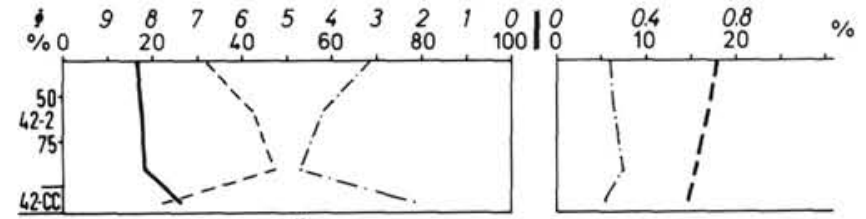

Figure 23. Sedimentological parameters for Core 650A-42X, Sections 2, $30 \mathrm{~cm}$ to CC. See Figure 2 for legend. 


\section{Stratigraphic Hypothesis}

No useful information; therefore, stratigraphic interpretation is not possible.

\section{Layer 22 (Core 47, Section 1, $47 \mathrm{~cm}$, to Section 2, $50 \mathrm{~cm}$ )}

The studied interval (thickness: $1.53 \mathrm{~m}$; depth below seafloor: 421.97-423.50 m) comprises: (1) a dark-colored lower part $(650 \mathrm{~A}-47 \mathrm{X}-2$, about $50 \mathrm{~cm}$, to $650 \mathrm{~A}-47 \mathrm{X}-1,103 \mathrm{~cm})$ which is intensively broken (drilling disturbances), and (2) above a relatively sharp contact, a light-colored upper part which shows irregularly bounded areas of slight color changes. For comparison, one sample from top of the underlying sediment $(650 \mathrm{~A}$ $47 \mathrm{X}-2,61-63 \mathrm{~cm}$ ) as well from the base of the superposed one $(650 \mathrm{~A}-47 \mathrm{X}-1,43-45 \mathrm{~cm})$ are studied.

\section{General Textural Data}

Grain size distribution and total carbonate as well as organic carbon contents are presented on Figure 24. The grain size data are not useful because of frequent secondary cementation of the sediments.

The total carbonate contents show a clear increase upcore, indicating a turbidite deposit. The observations from sand fractions support this idea. In the deeper part of the studied layer (low carbonate contents) the sand fractions consist of lumps of cemented sediment. The grain size of their components is relatively fine and decreases upcore. In the upper part (high carbonate contents), the sand fractions are represented almost completely by planktonic foraminifers which, however, are frequently cemented in Sample 650A-47X-1, 80-82 cm. The nannoplankton data document the same relations. Reworked nannoplankton is rare in all samples; autochthonous nannoplankton is rare in samples with low carbonate content but is frequent in those of high carbonate content.

$\mathrm{X}$-ray diffractometry shows quartz, calcite, and phillipsite. The latter is dominating mineral in those samples with low carbonate content, but subordinate in the carbonate-rich sediments.

The sample from the overlying deposit (650A-47X-1, 43-45 $\mathrm{cm}$ ) has relatively low carbonate content. The sand fraction consists completely of lumps of cemented sediments of varying grain sizes.

The sample from the underlying deposit (650A-47X-2, 61-63 $\mathrm{cm}$ ) has also relatively low carbonate content. The sand fraction consists almost completely of lumps of cemented fine-grained sediment.

The bulk mineralogy data for these two samples shows the same relations as mentioned above for the studied layer itself.

\section{Biogenic Content}

The two deepest samples (650A-47X-2, 33-35 cm, and 650A$47 \mathrm{X}-1,115-117 \mathrm{~cm}$ ) are barren. In $650 \mathrm{~A}-47 \mathrm{X}-1,94-96 \mathrm{~cm}$, and

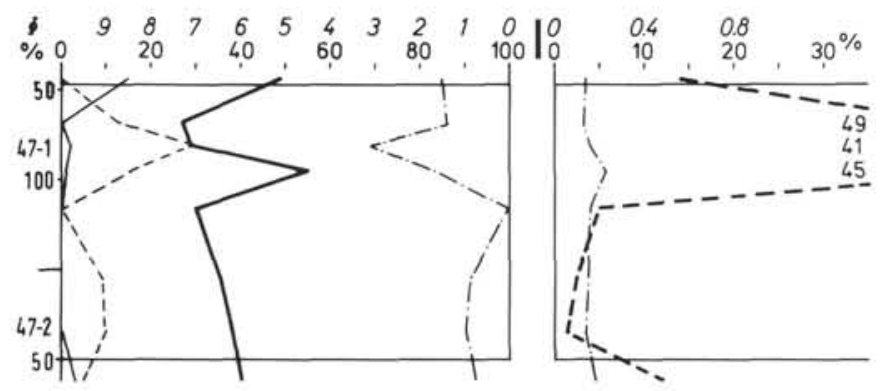

Figure 24. Sedimentological parameters for Core 650A-47X, Sections 1, $47 \mathrm{~cm}$ to $2,50 \mathrm{~cm}$. See Figure 2 for legend.
$650 \mathrm{~A}-47 \mathrm{X}-1,90-94 \mathrm{~cm}$, the sand fraction consists completely of planktonic foraminifers the preservation of which is good. All size fractions are present. The assemblages comprise abundant Globigerina quinqueloba and Globigerinoides ruber, common G. quadrilobatus, few Globorotalia inflata, Globigerinita glutinata, and rare Globigerinoides sacculifer (warm environment). In Sample 650A-47X-1, 80-82 cm, planktonic foraminifers are rare. The uppermost sample $(650 \mathrm{~A}-47 \mathrm{X}-1,67-69 \mathrm{~cm}$, presents a pure planktonic foraminiferal assemblage similar to $650 \mathrm{~A}-47 \mathrm{X}-1$, 94-96 cm, with minor differences (common Globigerina falconensis and few Globigerinella siphonifera) but the same climatic indication.

\section{Sedimentological Interpretation}

There is no doubt that we can interpret this layer as a turbidite (which originally had volcanic glass as dominating component) and its cover by a "normal" hemipelagic sediment.

The underlying deposit (650A-47X-2, 61-63 cm) may be an originally glass-containing turbidite too, which was followed directly by the next one without development of a cover of normal sediment.

The sample from the superposed deposit (650A-47X-1, 43$45 \mathrm{~cm}$ ) obviously documents the base of the next younger turbidite.

\section{Stratigraphic Hypothesis}

Overlying sediments: The base of Brunhes magnetozone has been determined in the interval between 650A-45X-2, 105-107 $\mathrm{cm}$, and $650 \mathrm{~A}-47 \mathrm{X}-1,38-40 \mathrm{~cm}$. Sample $650 \mathrm{~A}-47 \mathrm{X}-1,7-11 \mathrm{~cm}$, contains a warm assemblage similar to $650 \mathrm{~A}-47 \mathrm{X}-1,94-96 \mathrm{~cm}$, without Globigerinoides sacculifer and with rare Globigerina bulloides.

The layer itself: The upper part documents a period of warm environment.

Underlying sediments: no useful information.

Result: The determination of Brunhes/Matuyama magnetozone boundary gives an age of 0.73 m.y. In marine sediments, this boundary is usually determined in isotope Stage 19 .

The studied layer is older than Brunhes/Matuyama boundary. There is an alternative for its warm assemblage: isotope Stages 19 or 21. Since Globigerinoides sacculifer does not occur in Stage 21 of Site $653 \mathrm{~A}$, we can exclude this stage. Consequently, the studied layer should represent Stage 19.

\section{Layer 23 (Core 56, Section 1 to Section 3)}

The core (thickness: $3.18 \mathrm{~m}$; depth below seafloor: $508.20-$ $511.38 \mathrm{~m}$ ) is disturbed: there are few-centimeter-thick lumps of intact sediment in more or less regular intervals between totally broken or kneaded sediments. The lumps show always a somewhat darker color than the disturbed material. Within Sections $650 \mathrm{~A}-56 \mathrm{X}-1$ and $650 \mathrm{~A}-56 \mathrm{X}-3$, the sediments are obviously brittle, whereas those in Section $650 \mathrm{~A}-56 \mathrm{X}-2$ are rather soft. The samples were taken in most cases from the undisturbed lumps.

\section{General Textural Data}

Grain size distribution and contents of organic carbon and total carbonate are presented on Figure 25.

Grain size distribution: cannot be definitely interpreted. It gives the impression of nearly homogenous composition which may be somewhat falsified by slight cementation with phillipsite(?).

Organic carbon content oscillates between $0.2 \%$ and $0.3 \%$.

Total carbonate content increases upcore from $21 \%$ to $25 \%$.

Bulk mineralogy: quartz, calcite $\left(\mathrm{MgCO}_{3}\right.$ content around $2.5 \%$ ), dolomite (in most samples, but near to the identification limit), feldspar, phillipsite (only weak reflections).

Clay mineralogy (only two samples): illite $91 \%-95 \%, 7 \AA$ minerals (only chlorite?) $5 \%-9 \%$. 


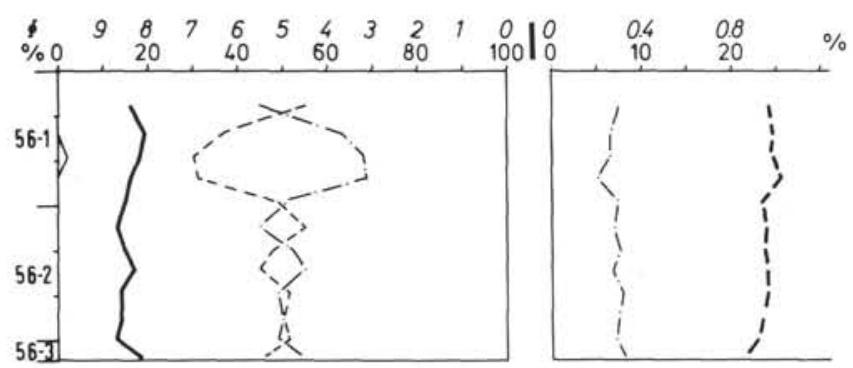

Figure 25. Sedimentological parameters for Core 650A-56X, Sections 1 to 3 . See Figure 2 for legend.

Sand sized components are very rare. Only Sample 650A$56 \mathrm{X}-1,94-96 \mathrm{~cm}$, contains a considerable amount of thin, platy fragments of the slightly cemented sediment.

\section{Sedimentological Interpretation}

We have not yet a clear idea about the character of these sediments. Cementation seems to play a subordinate rule (low content of phillipsite). Therefore, we can consider the grain size distribution as fairly original. Volcaniclastic material is missing; minerals which may originated from it (zeolites) do not occur in considerable amounts. The carbonate contents are relatively low but increase upcore. This can signalize turbidite character according to the studies we made of the layers of younger age. Then, this layer should belong to the upper, fine-grained part of a thicker turbidite (bad recovery).

\section{Stratigraphic Hypothesis}

Overlying sediments: Base of Jaramillo magnetic event is determined between 650A-51X-3, 31-33 cm, and 650A-52X-1, 80$82 \mathrm{~cm}$ (J. Channell, pers. comm. 1988). This gives an age of 0.98 m.y. The last occurrence of Helicosphaera sellii is reported from 650A-52X-CC (Shipboard Scientific Party, 1987, p. 152).

The layer itself: no information.

Underlying sediments: Top of Olduvai magnetozone has been determined in 650A-63X-3 (Shipboard Scientific Party, 1987, p. 153). This gives an age of $1.66 \mathrm{~m} . \mathrm{y}$.

Result: The studied layer cannot be precisely dated. It has an age between 0.98 and 1.66 m.y.

\section{DISCUSSION}

Some general findings, derived from the detailed descriptions, will be listed and discussed.

1. Twenty-three sediment intervals have been studied. From macroscopic aspects, they comprise different types of sediments: normally-graded sequences, "homogenous" sediments, and sand layers. Except for one layer (Layer 20), all others are interpreted to be turbidites or parts of them.

2. The thicknesses of the described complete turbidite layers vary between $0.33 \mathrm{~m}$ and about $40 \mathrm{~m}$.

3. Maximum mean size of the base sediments of the studied layers varies between 1 phi $(\phi)$ and $7 \phi$. The minimum mean size of the top sediments varies considerably less (between 7 and $9 \phi$ ). Intervals with coarse base (maximum mean size $5 \phi$ or coarser) do occur only from top of Site $650 \mathrm{~A}$ to Layer 9. This is exactly the interval in which APC coring method was applied. Below Layer 9, when XCB method was used, the maximum mean size of basal sediments of the studied layers is $5 \phi$ or finer. This observation supports the idea already expressed in the core descriptions (Shipboard Scientific Party, 1987) that the coarsergrained bases of turbidite layers have been washed out by the more aggressive coring method.
4. If we would like to interpret extremely all intervals of no recovery as indications for washed out, coarse-grained turbidite bases, we could not reconstruct turbidites as thick as Layers 6 (about $17 \mathrm{~m}$ ) and 9 (about $40 \mathrm{~m}$ ). Moreover, not all of the macroscopically "homogenous" intervals can be interpreted as finegrained upper parts of turbidites, but some of these intervals may, in fact, consist of a sequence of turbidites of very fine grain size spectra (such as Layer 16). Therefore, we can conclude that the frequency of thick turbidite layers is higher in the younger part of the stratigraphic sequence than in the older one.

5 . The top sediments of the turbidites are of different characters. In some cases (Layers 1, 5, 6, 7, 8, 14, 15, 16, and 18?), the turbidites terminate with sediments which show indeed almost or actually the highest carbonate contents of the respective sequence. However, the absolute values are relatively low $(20 \%$ or less) - too low for normal hemipelagic or even pelagic sediments which should have been deposited when the turbidite events died away. In these cases we have to consider the turbidites to be followed immediately by the succeeding ones, if we would not assume that the originally superposed "normal" sediments are eroded before deposition of the following turbidite. Such situations of erosion before deposition of the succeeding turbidite may have happened at the base of thick turbidites which are deposited from strong turbidity currents. The currents which deposited thin turbidite layers should not have been able to erode considerably.

In other cases (Layers 2, 3, 9, 10, 11, 12, 13?, 19, and 22), the turbidites are topped by sediments with relatively high absolute values of carbonate content (from about $25 \%$ to $50 \%$ ). These sediments can be considered as more or less normal deposits which consist of considerable amounts of calcareous particles from biogenic production in the water column.

In few cases (Layers 4, 17, 21, and 23), the upper boundaries of the layers are unknown, and therefore an interpretation is senseless.

6 . Some of the studied layers $(2,13,15,21$, and 23) show generally fine mean size spectra (between 8 and $9 \phi$, and between 6 and $7 \phi$ in Layer 15) even if they are graded. Their restricted grain size distribution points to the availability of large amounts of relatively well sorted material and the lack of coarse-grained ones. In the cases of incomplete layers, when the lower contact is unknown (Layers 21 and 23), we can consider these layers as fine-grained upper parts of thicker turbidites. Any section of the upper parts of the thick turbidite Layers 6 and 9, for example, would give a very similar picture like Figures 23 or 25 . However, the layers mentioned above could also belong to the group of Layers $(2,13$, and 15$)$ which are completely recovered and really contain only fine-grained and only slightly (if any) graded material.

This type of deposit is best comparable with that named "unifite" by Stanley (1981). Stanley explains the origin of unifites by "basinward displacement" of material "involving repeated failure and redeposition, slope-relief bypassing resulting in fining and homogenization downslope and modification by hydraulic jump effects at the base-of-slope" (Stanley, 1981., p. 77). Stanley's statement that unifites occur in small, topographically restricted depressions, however, has to be modified. This type of deposit obviously occurs also in larger abyssal plains. A thick homogenous sequence (about $10 \mathrm{~m}$ thick) has been described from the Ionian Abyssal Plain (Hieke, 1984). This layer covers an area of at least $3800 \mathrm{~km}^{2}$ and comprises a volume of at least $38 \mathrm{~km}^{3}$. Therefore, the occurrence of relatively thin unifites within the Marsili Basin should not be considered as unusual.

The present morphological situation around the Marsili Basin is roughly outlined on Figure 1. Today, gravity-controlled transport of material can happen along the indicated paths. The map shows also areas which possibly act as traps for material 
transported by turbidity currents. Their number could be completed by the Cefalú Basin between Sicily and the Eolian Islands, however, at present, it may play only a subordinate role for sediment transport toward Marsili Basin. Basins in which sediments were accumulated during Neogene-Quaternary time surround the Marsili Basin in north, east, and south (Fabbri et al., 1981; Barone et al., 1982). Their function could have changed during time as is documented for the Gioia Basin (south of Stromboli) which is now crossed by the Stromboli Canyon running into Marsili Basin (Fabbri et al., 1981). So, the morphologic/tectonic preconditions for the origin of unifites existed during time.

7. Turbidite sediments are deposited from events which were obviously different in intensity, regional importance, source, and material available for transport.

Within the whole sedimentary sequence of Site 650 we have to expect: (1) that the material of some turbidites has been transported directly from shallow water areas into the abyssal plain (sometimes enriched with material eroded on the way); (2) that some turbidites consist of repeatedly mobilized and displaced material. This may have been grain-size- as well componentsorted with the tendency to become a unifite; and (3) turbidites, the components of which are displaced only from intermediate water depths, where they originally were deposited by ash-fall.

Combinations of these pure types are very likely. Furthermore, it could be possible that the very thick turbidite deposits (occurring within the whole Marsili Basin in almost constant thickness?) are the product of several currents which came from different sources but were triggered by the same pan-Tyrrhenian event.

8. Volcaniclastic material (glass, pumice) is a prominent constituent of all studied layers from top of Site 650 to Core 29 . From Core 31 to Core 56 (the deepest studied interval), no volcaniclastic material was observed, but zeolites (phillipsite and, in one case, analcime) are always present. It is most likely that they originated from altered glass particles.

The amount of volcaniclastic material and of zeolites respectively indicate that volcanism has been active during the whole studied time with varying but sometimes large intensities. Nevertheless, the number of true ash-fall layers seems to be small. It is obvious that most part of the volcaniclastic material originally deposited as ash-fall layers has been remobilized by turbidity currents.

A detailed study of volcaniclastic material is still outstanding. It should supply better knowledge about source areas of turbidites as well as of volcanic activities within different parts of the neighborhood of Marsili Basin.

9. Shallow water biogenic material and lithic fragments are of great interest to ascertain the source areas of turbidites. Both groups of components occur in Layers 1, 3, 4, 9, 10, 11, and 19. The shallow water origin of components is best documented in Layer 9 by bryozoans, benthic foraminifers, ostracodes, plant remains, and fragments of metamorphic rocks.

The benthic foraminifers give the following special information: there are three principal elements of species in the studied layers representing inner neritic (zone 1), upper epibathyal (zone 3 ), and lower mesobathyal (zone 7) depths. The outer neritic species occur together with inner neritic or upper epibathyal forms, but usually they are not frequent.

Inner neritic species form a mode in the histograms (Fig. 3) of some horizons of Layers 1, 3, 6, 9, and 11. In other horizons of the same layers, upper epibathyal species are frequent. They are generally frequent within Layers $4,7,8,10,18$, and 19. Therefore, we have to assume that at least parts of the material of Layers $1,3,4,6,7,8,9,10,11,18$, and 19 came from inner neritic to upper epibathyal depths. This assumption includes complications such as preceding transport and mixing of material as well as admixtures of sediments which have been eroded in greater depths during the final transport to the deep.

The Pleistocene sediments of Site 650 should have been deposited in lower mesobathyal depths. This statement is based on following information: (a) The lower mesobathyal zone is represented by Articulina tubulosa. It has very thin and elongate tubelike tests and is very fragile. Most of the specimens are broken. Nevertheless, we can assume that they are nearly autochthonous. Even if they were moved, it must have been only a short distance compared with the way of the turbidity currents. (b) Articulina tubulosa is living also in upper mesobathyal depths, there together with Gyroidina spp., Gyroidinoides spp., Uvigerina spp., etc. In our samples, however, these associated species are very rare. Therefore, most of the Articulina tubulosa are considered to indicate the lower mesobathyal zone. (c) Below that part of Pleistocene from which layers are studied in this paper, and also at the nonturbiditic horizons between studied layers, $A$. tubulosa is a dominant species. In this horizon occurs almost the same fauna as Assemblage E of Hasegawa et al. (this volume), which is regarded as lower mesobathyal fauna. Up to now, no details of the respective source areas are available. Perhaps the study of the metamorphic rocks can give hints.

10. The clay minerals show relatively simple assemblages. Illite and irregular mixed layer minerals are the most frequent components. Smectite has been identified only as constituent of mixed layers, never as pure mineral. In most cases kaolinite dominates chlorite. Only in a few samples such as Layers 10 and 11 does chlorite prevail over kaolinite.

The results presented in this paper show the value of the information from x-ray analyses made on board and presented in the core descriptions (Shipboard Scientific Party, 1987, Fig. 10) to be relative. The climatostratigraphic interpretation given in Figure 11 of that report (Shipboard Scientific Party, 1987) is disproved by the recognition of turbidite Layer 6 (40.3-61.8 mbsf, "representing" isotope Stages 5a and part of 5b), Layer 8 (69.875 mbsf, "representing" deepest part of Stage 5b and Stage 5c), and Layer 9 (92.8-132.1 mbsf, "representing" part of Stage 5e and an indefinite deeper interval). The idea that "smectite/chlorite" peaks show a negative correlation with carbonate peaks (Shipboard Scientific Party, 1987, Fig. 11) is not proved by the original figure itself.

11. At present, the content of organic carbon in turbidite sediments cannot be used for the identification of special sources.

12. The target to establish a calendar of volcanic and/or tectonic events in and around the Marsili Basin cannot be reached easily as is inferred from the presented data. First of all, we need a sufficiently exact time scale. It can be set up only from normally deposited sediments with no subsequent reworking. These, again, are obviously rare, since the greatest part of the sedimentary sequence consists of turbidites. With regard to these circumstances, we should be very careful using material for analyses to establish any type of stratigraphy. The most correct way must be to study first the nature of the sediments and then to select material for analyses. This process has been used to apply to the evaluation of planktonic foraminifer assemblages and the succeeding oxygen isotope study.

A first but still preliminary result is the stratigraphic interpretation of Layer 9 (the 40 -m-thick turbidite, recovered from 93-132 m below seafloor). The top sediment was deposited during isotope Stages $5 \mathrm{~b}$ or $5 \mathrm{~d}$ (based on climatic interpretation of planktonic foraminifers). The assemblage from a sample immediately below Layer 9 is interpreted as indicating Stage 5e. This would mean that the deposition of Layer 9 may be connected 
with the Tyrrhenian transgression. This again would make sense to interpret the turbidity current as caused by sea level rise and would explain the large amount of mobilized material.

13. The stratigraphic interpretation of the studied layers is shown on Table 4. The first attempt to date the layers is based on information from the layers themselves and their overlying and underlying sediments. We cannot improve the stratigraphic interpretation of Layers 1 through 13 by discussion. For older layers we can try to find arguments from nannoplankton zone boundary NN19/NN20. It is determined in Core 650A-37X and is situated within isotope Stage 12. Since Layers 14 through 18 are situated above boundary NN19/NN20, they all have to be not older than Stage 12. The planktonic foraminiferal assemblage of Sample 650A-26X-1, 33-37 cm, represents a warm environment. Since it is superposing NN19/NN20 boundary, it should be situated in Stage 11. Consequently, Layers 14 through 18 cannot be older than Stage 11. Because of lack of normal sediments, the planktonic foraminiferal assemblages of which we could use for stratigraphic interpretation within the considered interval, we can only state that Layers 14 through 18 should have been deposited during Stages 10 and/or 11 .

Between Layers 19 and 20, there exist five samples from nearly normal sediments. Sample 650A-38X-1, 92-96 cm, represents a warm environment interpreted to be Stage 13. The assemblage of Sample 650A-39X-2, 37-41 cm, is characterized by abundant Globorotalia inflata and Globigerina quinqueloba, common dextral Neogloboquadrina pachyderma, few dextral Globorotalia scitula, dextral Neogloboquadrina acostaensis and Orbulina universa, rare Globigerina pseudoobesa, and Globigerinoides cy. clostomus (temperate environment). The composition of the assemblage of Sample $650 \mathrm{~A}-39 \mathrm{X}-3,36-40 \mathrm{~cm}$, differs from the

Table 4. Stratigraphic interpretations of the studied layers.

\begin{tabular}{|c|c|c|}
\hline Studied interval & $\begin{array}{l}\text { Direct stratigraphic } \\
\text { interpretation }\end{array}$ & $\begin{array}{l}\text { Interpretation } \\
\text { after discussion }\end{array}$ \\
\hline $\begin{array}{l}\text { Layer } 1(650 \mathrm{~A}-2 \mathrm{H}-5,40 \mathrm{~cm} \text { to } \\
\quad 650 \mathrm{~A}-2 \mathrm{H} 6,150 \mathrm{~cm})\end{array}$ & $\begin{array}{l}\text { not older than Stage 2, } \\
\text { most likely within } \\
\text { Stage } 2\end{array}$ & \\
\hline Layer $2(650 \mathrm{~A}-3 \mathrm{H}-3,17-149 \mathrm{~cm})$ & within Stage 2? & \\
\hline Layer $3(650 \mathrm{~A}-3 \mathrm{H}-5,22-87 \mathrm{~cm})$ & within Stage 2? & \\
\hline Layer $4(650 \mathrm{~A}-5 \mathrm{H}-3,63-150 \mathrm{~cm})$ & Stages 2 or 3 & \\
\hline Layer $5(650 \mathrm{~A}-5 \mathrm{H}-4,56-94 \mathrm{~cm})$ & ? & \\
\hline $\begin{array}{l}\text { Layer } 6(650 \mathrm{~A}-5 \mathrm{H}-6,0 \mathrm{~cm} \text { to } \\
650 \mathrm{~A}-7 \mathrm{H}-\mathrm{CC})\end{array}$ & younger than Stage Se & \\
\hline Layer $7(650 \mathrm{~A}-8 \mathrm{H}-4,94-146 \mathrm{~cm})$ & younger than Stage Se & \\
\hline $\begin{array}{l}\text { Layer } 8(650 \mathrm{~A}-8 \mathrm{H}-6,52 \mathrm{~cm} \text { to } \\
\quad 650 \mathrm{~A}-9 \mathrm{H}-3,69 \mathrm{~cm})\end{array}$ & $\begin{array}{l}\text { within or above Stages } 4 \\
\text { or } 6 \text { (we favorize } \\
\text { Stage } 4 \text { ) }\end{array}$ & \\
\hline $\begin{array}{l}\text { Layer } 9(650 \mathrm{~A}-11 \mathrm{H}-2,58 \mathrm{~cm} \text { to } \\
650 \mathrm{~A}-14 \mathrm{X}-\mathrm{CC})\end{array}$ & Stage 5? & \\
\hline $\begin{array}{l}\text { Layer } 10(650 \mathrm{~A}-17 \mathrm{X}-1 \\
\quad 74-121 \mathrm{~cm})\end{array}$ & $\begin{array}{l}\text { Stage } 8 \text { (uppermost } \\
\text { part)? }\end{array}$ & \\
\hline $\begin{array}{l}\text { Layer } 11(650 \mathrm{~A}-20 \mathrm{X}-1,67 \mathrm{~cm} \text { to } \\
650 \mathrm{~A}-20 \mathrm{X}-\mathrm{CC})\end{array}$ & younger than Stage 9 & \\
\hline Layer $12(650 \mathrm{~A}-22 \mathrm{X}-1,12-70 \mathrm{~cm})$ & $?$ & \\
\hline Layer $13(650 \mathrm{~A}-24 \mathrm{X}-2,12-89 \mathrm{~cm})$ & Stage $10 ?$ & \\
\hline $\begin{array}{l}\text { Layer } 14(650 \mathrm{~A}-25 \mathrm{X}-1,120 \mathrm{~cm} \text { to } \\
\quad 650 \mathrm{~A}-25 \mathrm{X}-\mathrm{CC})\end{array}$ & $?$ & Stages 10 and/or 11 \\
\hline $\begin{array}{l}\text { Layer } 15(650 \mathrm{~A}-26 \mathrm{X}-1,43 \mathrm{~cm} \text { to } \\
650 \mathrm{~A}-26 \mathrm{X}-\mathrm{CC})\end{array}$ & ? & Stages 10 and/or 11 \\
\hline $\begin{array}{l}\text { Layer } 16(650 \mathrm{~A}-27 \mathrm{X}-1,70 \mathrm{~cm} \text { to } \\
\quad 650 \mathrm{~A}-27 \mathrm{X}-\mathrm{CC})\end{array}$ & $?$ & Stages 10 and/or 11 \\
\hline $\begin{array}{l}\text { Layer } 17 \text { (650A-29X-1, } 22 \mathrm{~cm} \text { to } \\
650 \mathrm{~A}-29 \mathrm{X}-\mathrm{CC})\end{array}$ & ? & Stages 10 and/or 11 \\
\hline $\begin{array}{l}\text { Layer } 18(650 \mathrm{~A}-31 \mathrm{X}-2,74 \mathrm{~cm} \text { to } \\
\quad 650 \mathrm{~A}-31 \mathrm{X}-\mathrm{CC})\end{array}$ & ? & Stages 10 and/or 11 \\
\hline Layer $19(650 \mathrm{~A}-38 \mathrm{X}-1,40-73 \mathrm{~cm})$ & Stage 13 ? & \\
\hline Layer $20(650 \mathrm{~A}-42 \mathrm{X}-1,0-25 \mathrm{~cm})$ & $?$ & Stage 19 \\
\hline $\begin{array}{l}\text { Layer } 21(650 \mathrm{~A}-42 \mathrm{X}-2,30 \mathrm{~cm} \text { to } \\
\quad 650 \mathrm{~A}-42 \mathrm{X}-\mathrm{CC})\end{array}$ & $?$ & Stage 19 \\
\hline $\begin{array}{l}\text { Layer } 22(650 \mathrm{~A}-47 \mathrm{X}-1,47 \mathrm{~cm} \text { to } \\
\quad 650 \mathrm{~A}-47 \mathrm{X}-2,50 \mathrm{~cm})\end{array}$ & Stage 19 & \\
\hline $\begin{array}{l}\text { Layer } 23(650 \mathrm{~A}-56 \mathrm{X}-1 \text { to } \\
\quad 650 \mathrm{~A}-56 \mathrm{X}-3)\end{array}$ & $?$ & \\
\hline
\end{tabular}

previous one by the occurrence of few Globigerinoides ruber, $G$. elongatus, and Neogloboquadrina dutertrei (temperate warm). The assemblage of Sample 650A-39X-6, 38-42 cm, differs from the previous one by the missing of Globorotalia inflata, the occurrence of common sinistral Globorotalia truncatulinoides excelsa and Globigerina falconensis and rare Globigerinoides trilobus (warm environment). Finally the assemblage of Sample $650 \mathrm{~A}-39 \mathrm{X}-6,127-131 \mathrm{~cm}$, differs from the previous one by the occurrence of common Globorotalia inflata, few Globigerinoides conglobatus, rare G. quadrilobatus, and G. sacculifer (warm environment).

Based on the comparison with Site 653A where Globigerinoides sacculifer occurs in Stages 13 and 19, we can interpret Sample 650 A-39X-6, $127-131 \mathrm{~cm}$, to represent Stages 13 or 19. Since Samples 650A-39X-3, 36-40 cm, and 650A-39X-2, 37-41 $\mathrm{cm}$, document a relative upward cooling, Sample 650A-39X-6, $127-131 \mathrm{~cm}$, cannot belong to Stage 13 which is already found in Sample 650A-38X-1, 92-96 cm. Therefore, the level of 650A$39 \mathrm{X}-6,127-131 \mathrm{~cm}$, has to be interpreted as Stage 19.

The interval including Samples $650 \mathrm{~A}-39 \mathrm{X}-6,38-42 \mathrm{~cm}, 650 \mathrm{~A}-$ $39 \mathrm{X}-3,36-40 \mathrm{~cm}$, and $650 \mathrm{~A}-39 \mathrm{X}-2,37-41 \mathrm{~cm}$, shows warm environments with a relative cooling upward. One can only speculate that Sample 650A-39X-3, 36-40 cm: (a) could represent Stage 19 (together with $650 \mathrm{~A}-39 \mathrm{X}-6,38-42 \mathrm{~cm}$, and $650 \mathrm{~A}-39 \mathrm{X}-$ $6,127-131 \mathrm{~cm})$. Then Sample 650A-39X-2, 37-41 cm, should indicate the transition to Stage 18; (b) could represent Stage 17. Then Sample 650A-39X-2, 37-41 cm, should indicate the transition to Stage 16; or (c) could represent Stage 15. Then Sample $650 \mathrm{~A}-39 \mathrm{X}-2,37-41 \mathrm{~cm}$, should indicate the transition to Stage 14 and the interval between $650 \mathrm{~A}-39 \mathrm{X}-3,36-40 \mathrm{~cm}$, and $650 \mathrm{~A}-$ $39 \mathrm{X}-3,36-40 \mathrm{~cm}$ could comprise Stages 16 through 18.

Further speculations can be made about the interval of no recovery in Core $650 \mathrm{~A}-38 \mathrm{X}$ which has to include the time of isotope Stages 14 through 18 or various parts of them, depending on the alternatives discussed for the sediments of Core $650 \mathrm{~A}$ $39 X$. Isotope Stage 19 has been presumed for Layer 22, too. This means that all sediments deposited between Layers 20 and 22 (about $31 \mathrm{~m}$ thickness) should represent isotope Stage 19 (time span of only $20,000 \mathrm{yr}$ ).

14. A preliminary evaluation of the age/depth relations give hints that the calculated sedimentation rates (Shipboard Scientific Party, 1987, p. 168) can be specified in the interval from top to about $420 \mathrm{mbsf}$ insofar as there are two levels of very rapid sedimentation. One is documented at least by Layer 9 (92.8-132.1 mbsf). The other one results in the interval between about 220 and 350 mbsf where a mean sedimentation rate of about $75 \mathrm{~cm} / 1000 \mathrm{yr}$ is calculated. During the other periods of the upper $420 \mathrm{~m}$ of Site 650 , the mean sedimentation rate is distinctly smaller.

\section{SUMMARY}

The current study shows that most of the sediments of Site 650 have been deposited from turbidity currents. So-called homogenous intervals are in fact normally graded or tend to become unifites as end-members of repeated mobilization resulting in the loss of coarse-grained components.

The composition of the layers vary between (1) mixtures of land-derived, volcaniclastic and shallow water as well as openmarine biogenic particles and (2) rather monotonous, volcanicglass-dominated assemblages.

All imaginable triggering events may have acted (shakes released by volcanic activity and/or true tectonic movements as well as sea-level changes).

Ash-fall layers which directly document volcanic activity seem to be rarely preserved, since their material has been often remobilized and displaced by turbidity currents. 
In deeper parts of the sedimentary sequence (from about $280 \mathrm{~m}$ below seafloor downward) volcanic glass is totally transformed into zeolites.

\section{ACKNOWLEDGMENTS}

The help of M. Bauer, D. Ranis, H. Schuster, and S. Wamsler.during the laboratory work is gratefully acknowledged. We thank Dr. J. Froh for technical assistance in the operation of SEM and Drs. H. Köster, J. Mascle, J.-P. Rehault, R. Sartori, and G. Zuffa for discussions and stimulation.

A part of this study was made while S. Hasegawa was a visitor at Museum National d'Histoire Naturelle (MNHN) in Paris. He thanks Institut de Paléontologie of MNHN for the hospitality.

The study is supported by the Deutsche Forschungsgemeinschaft (Germany) as well as by C.N.R.S. (France).

\section{REFERENCES}

Barone, A., Fabbri, A., Rossi, S. and Sartori, R., 1982. Geological structure and evolution of the marine areas adjacent to the Calabrian Arc. Earth. Evol. Sci., 3:207-221.

Biscaye, P. E., 1965. Mineralogy and sedimentation of recent deep-sea clay in the Atlantic Ocean and adjacent seas and oceans. Geol. Soc. Am. Bull., 76:803-832.

Broecker, W. S., and Van Donk, J., 1970. Insolation changes, ice volumes, and the ${ }^{18} \mathrm{O}$ record in deep-sea cores. Rev. Geophys. Spac. Phys., 8:169-198.

Fabbri, A., Gallignani, P., and Zitellini, N., 1981. Geologic evolution of the peri-Tyrrhenian sedimentary basins. In Wezel, F. C. (Ed.), Sedimentary Basins of Mediterranean Margins. Bologna (Technoprint), 101-126.

Fabricius, F., and Müller, S., 1970. A buret cylinder for grain-size analysis of silt and clay (with Algol-Program). Sedimentology, 14:39-50.

Goldsmith, J. R., and Graf, D. L., 1958. Relation between lattice constants and composition of the $\mathrm{Ca}-\mathrm{Mg}$ carbonates. Am. Mineralog., 43:84-101.

Hieke, W., 1984. A thick Holocene homogenite from the Ionian Abyssal Plain (Eastern Mediterranean). Mar. Geol., 55:63-78.

Muerdter, D. R., and Kennett, J.P., 1983. Late Quaternary planktonic foraminiferal biostratigraphy, Strait of Sicily, Mediterranean Sea. Mar. Micropaleontol., 8:339-359.
Nachite, D., 1984. Les ostracodes actuels des plates-formes et du domaine profond de Méditerranée occidentale: leur intérêt pour l'évolution paléohydrologique au Quaternaire terminal [Thèsis $3 \mathrm{e}$ cycle]. Université Bordeaux.

Peypouquet, J. P., 1977. Les ostracodes et la connaissance des paléomilieux profonds. Application au Cénozoïque de l'Atlantique nordoriental [Thèse Doct. Etat.]. Université Bordeaux I.

Peypouquet, J. P., and Nachite, D., 1984. Les ostracodes en Méditerranée nord-occidentale. In Bizon, J. J., and Burollet, P. F. (Eds.), "ECOMED", 150-169.

Pflum, C. E., and Frerichs, W. E., 1976. Gulf of Mexico deep-water foraminifers. Spec. Publ. Cushman Found. Foraminiferal Res., 14: $1-125$.

Phleger, F. B., Parker, F. L., and Peirson, J. F., 1953. North Atlantic Foraminifera. Repts. Swed. Deep-Sea Exped., 7:3-122.

Pujos-Lamy, A., 1973. Répartition bathymetrique des Foraminifères benthiques profonds du Golfe du Gascogne: Comparaison avec d'autres aires oceaniques. Rev. Esp. Micropaleontol., 5:213-234.

Shipboard Scientific Party, 1987. Site 650. In Kastens, K. A., Mascle, J., et al., Proc. ODP, Init. Repts., 107: College Station, TX (Ocean Drilling Program), 129-285.

Stanley, D. J., 1981. Unifites: structureless muds of gravity-flow origin in Mediterranean basins. Geo-Mar. Letters, 1:77-83.

Tennant, C. B., and Berger, R. W., 1957. X-ray determination of dolomite-calcite ratio of a carbonate rock. Am. Mineralog., 42:23-29.

Vénec-Peyré, M.-Th., 1983. Étude de la distribution des foraminifères vivant dans la baie de Banyuls-sur-Mer. In Bizon, J. J., and Burollet, P. F. (Eds.), “ECOMED”, 60-80.

Wewer, R. F., 1975. Mineralogische Untersuchungen an der Tonmineralassoziation pleistozäner bis rezenter Sedimente des Ionischen Meeres [Diplom-Arbeit Mineralogie]. Technische Universität München.

Wright, R., 1979. Neogene benthic foraminifers from DSDP Leg 42A, Mediterranean Sea. In Hsü, K. J., Montadert, L. et al., Init. Repts. DSDP, 42 (Pt. 1): Washington (U.S. Govt. Printing Office), 709726.

Date of initial receipt: 8 February 1988

Date of acceptance: 10 January 1989

Ms 107B/120 


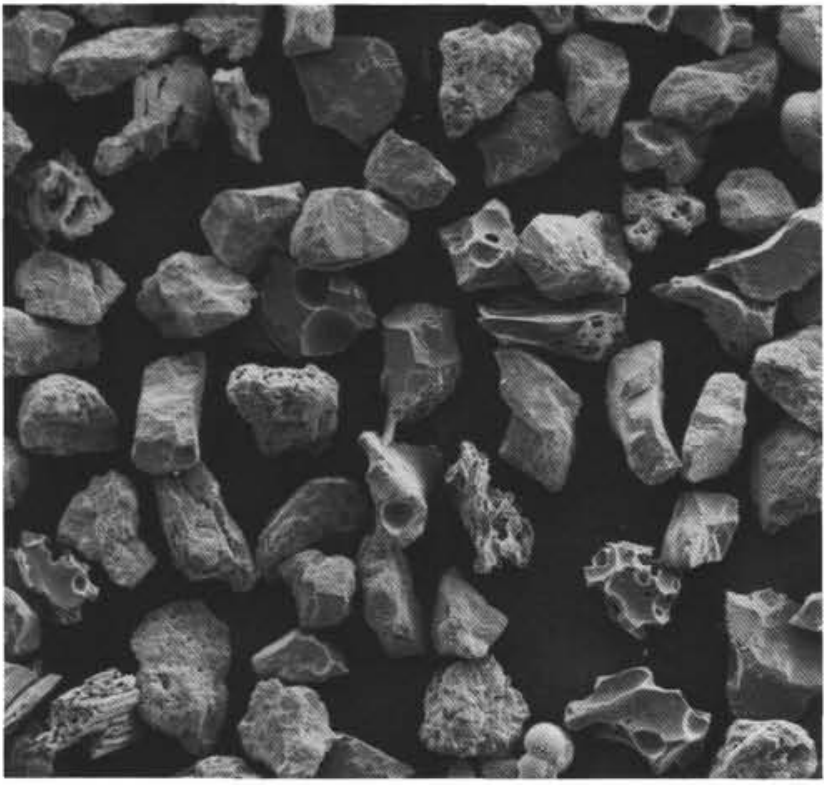

1

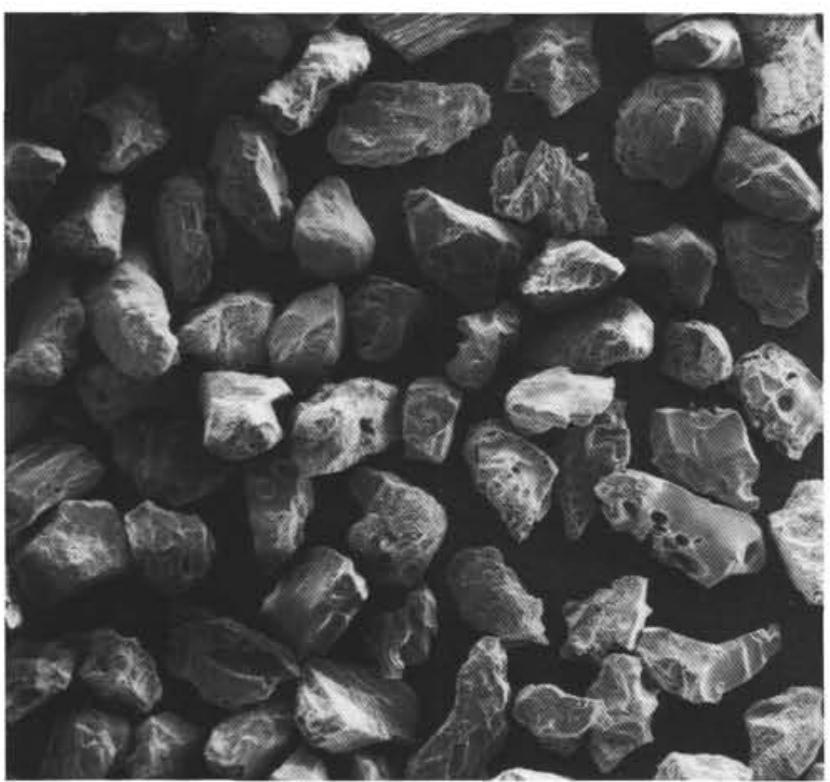

3

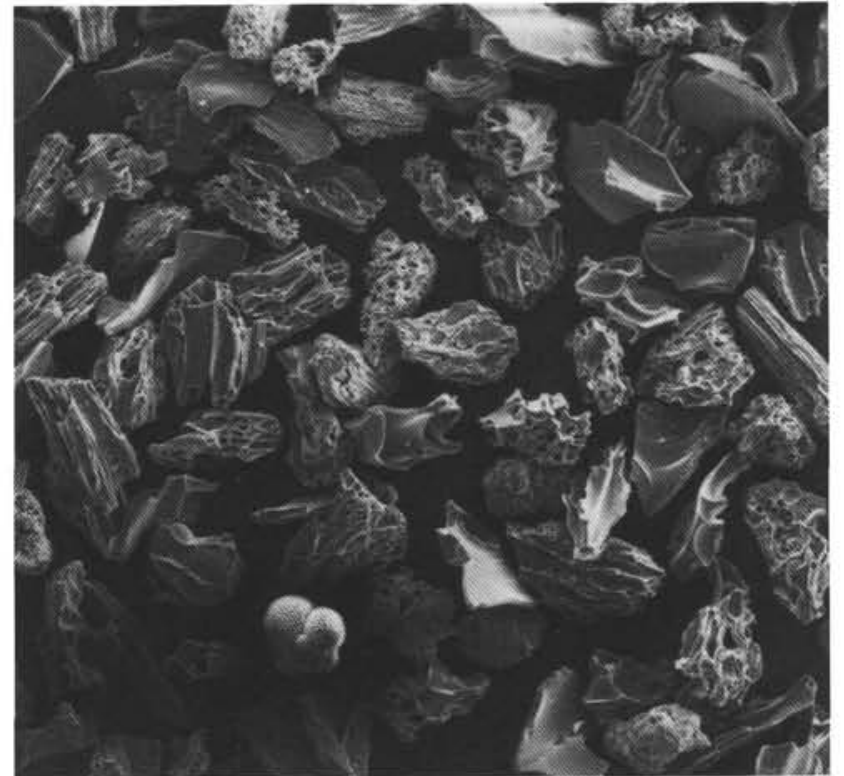

2

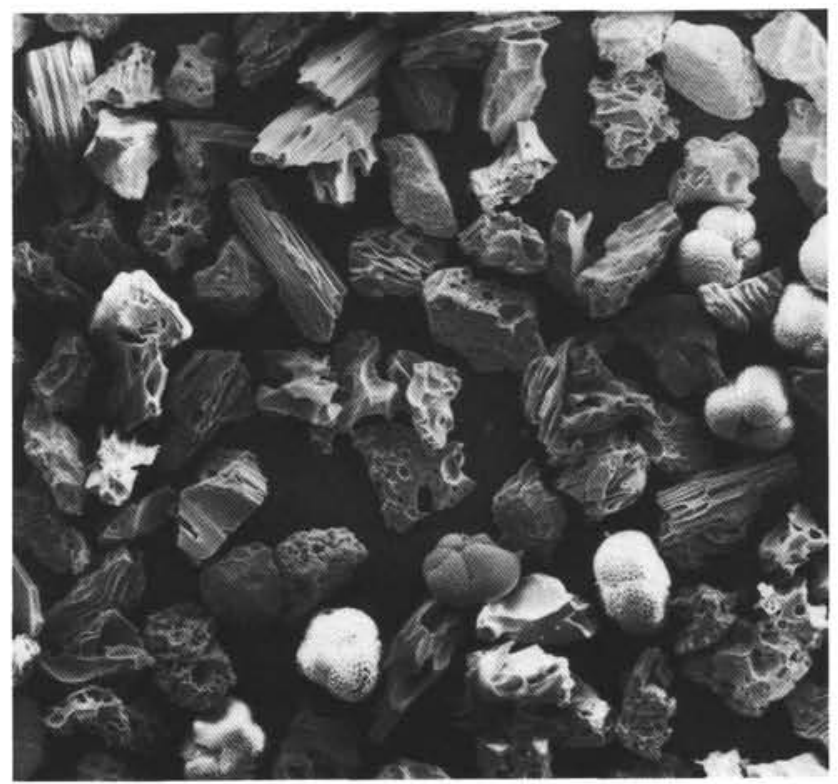

4

$100 \mu \mathrm{m}$

Plate 1. Compositions of sand fractions $125-177 \mu \mathrm{m}$. 1. Layer 3 (Core 650A-3H-5, 22-87 cm), Sample 650A-3H-5, 85-87 cm. 2. Layer 6 (Core $650 \mathrm{~A}-5 \mathrm{H}-6,0 \mathrm{~cm}$, to Core $650 \mathrm{~A}-7 \mathrm{H}-\mathrm{CC}$ ), Sample $650 \mathrm{~A}-7 \mathrm{H}-1,20-22 \mathrm{~cm}$. 3. Layer 9 (Core $650 \mathrm{~A}-11 \mathrm{H}-2,58 \mathrm{~cm}$, to Core $650 \mathrm{~A}-14 \mathrm{X}-\mathrm{CC}$ ), Sample $650 \mathrm{~A}-14 \mathrm{X}-\mathrm{CC}, 12-14 \mathrm{~cm}$. 4. Same layer, Sample 650A-12H-3, 35-37 cm. 


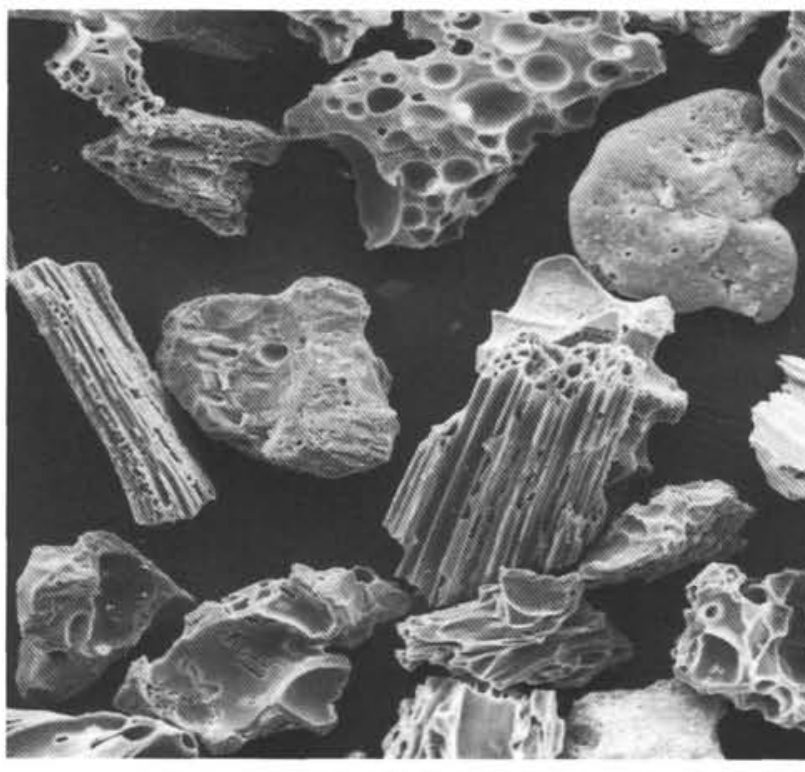

1

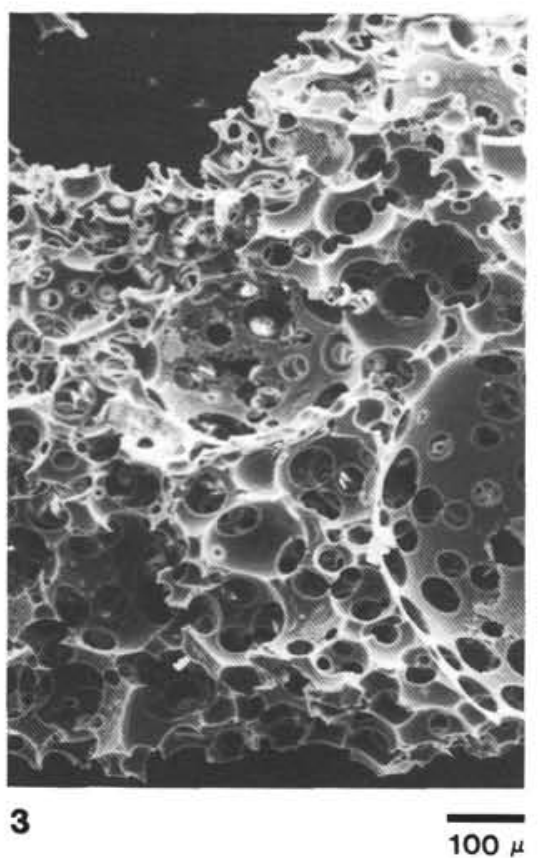

$100 \mu \mathrm{m}$

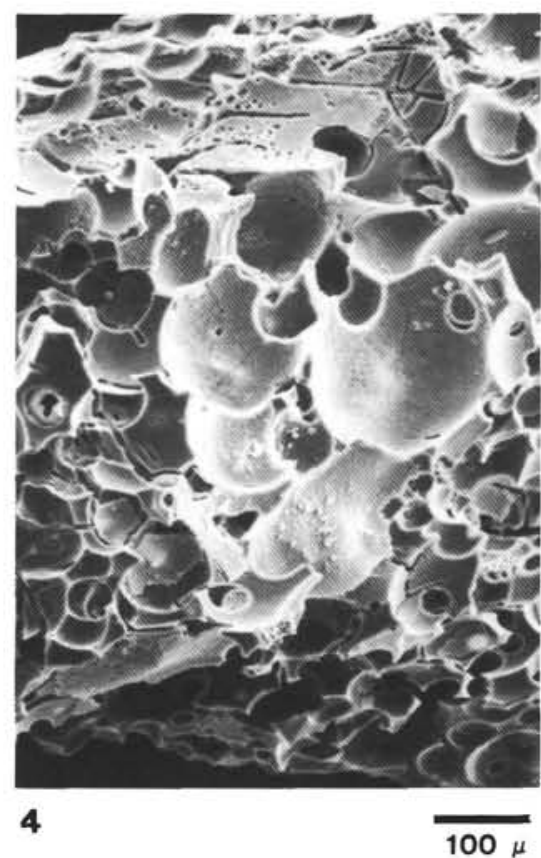

2

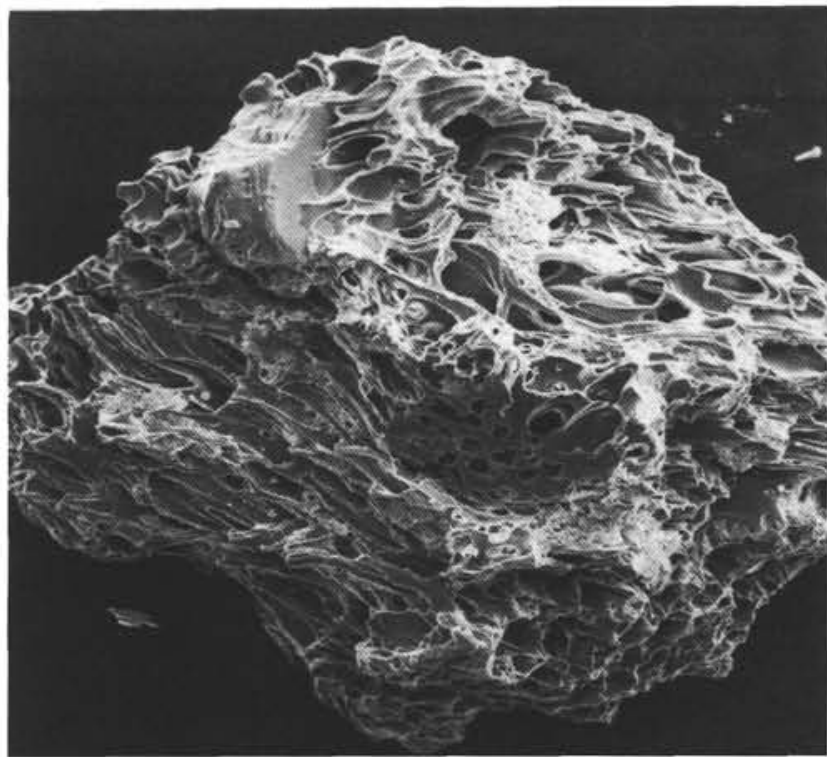

$1000 \mu \mathrm{m}$

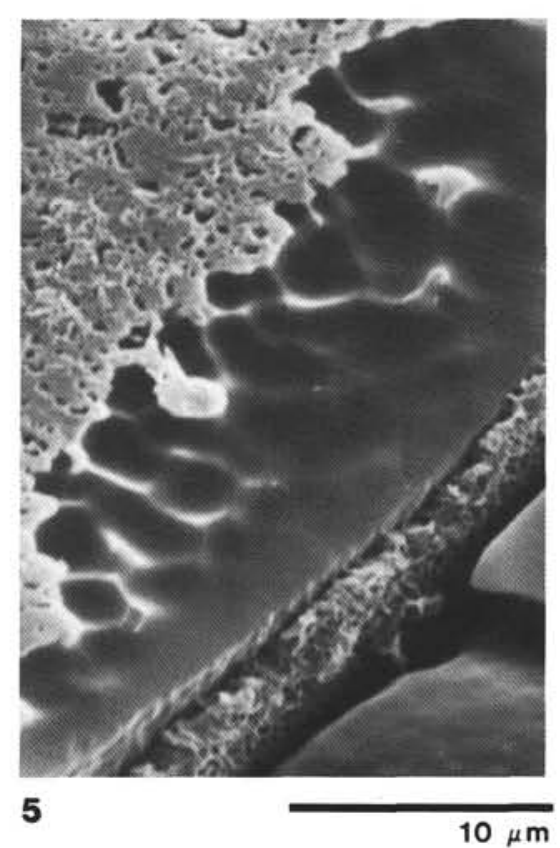

Plate 2. Volcaniclastic components of sand fractions. 1. Co-occurrence of different types of pumice (Sample 650A-12H-3, 35-37 cm, 125-177 $\mu \mathrm{m})$. 2. Pumice shard including pyrogenic mineral (Sample 650A-14X-CC, 12-14 cm). 3. Pumice shard with spheric vesicles (Sample 650A-14XCC, $12-14 \mathrm{~cm}$ ). 4. Pumice shard with spheric vesicles (Sample 650A-14X-CC, 12-14 cm). 5. Corroded vesicle wall and neoformation of minerals in fissures. (Detail from Fig. 4 central upper part). 

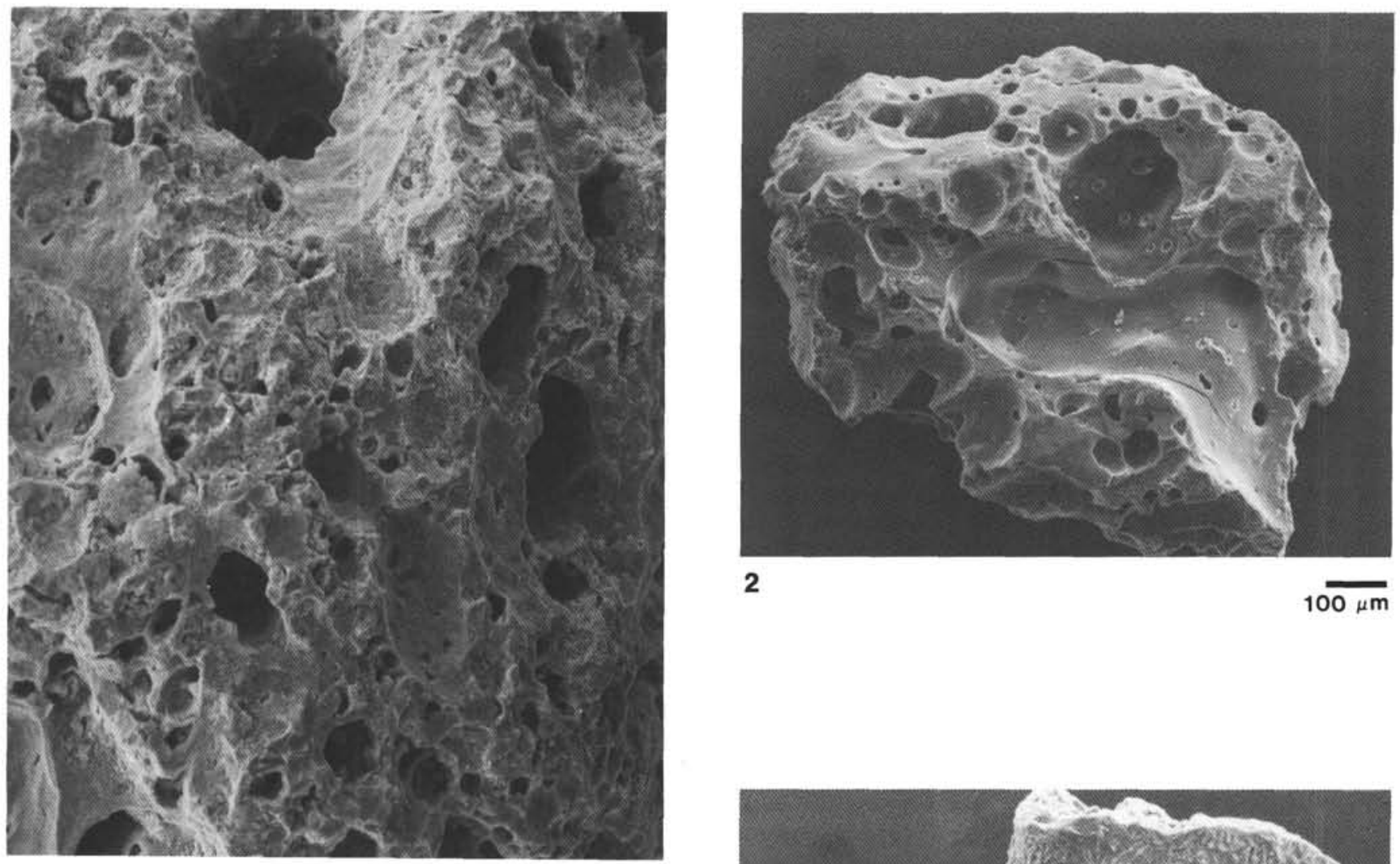

1

$\overline{100 \mu \mathrm{m}}$

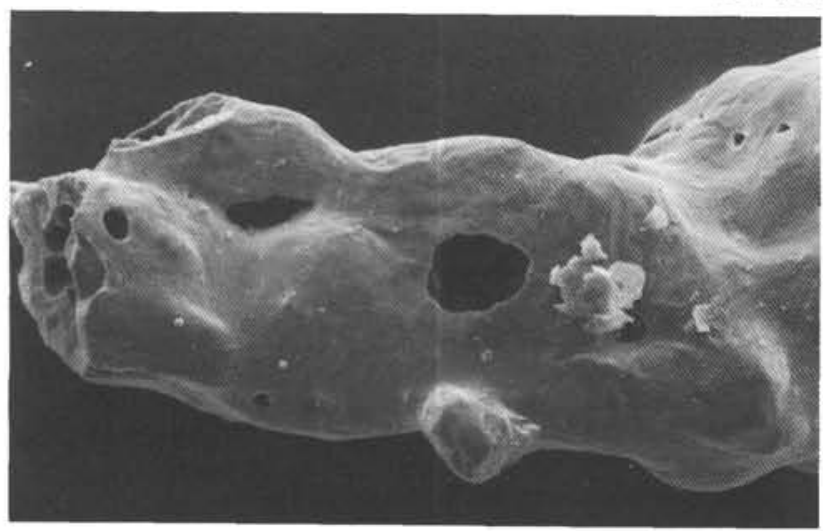

3
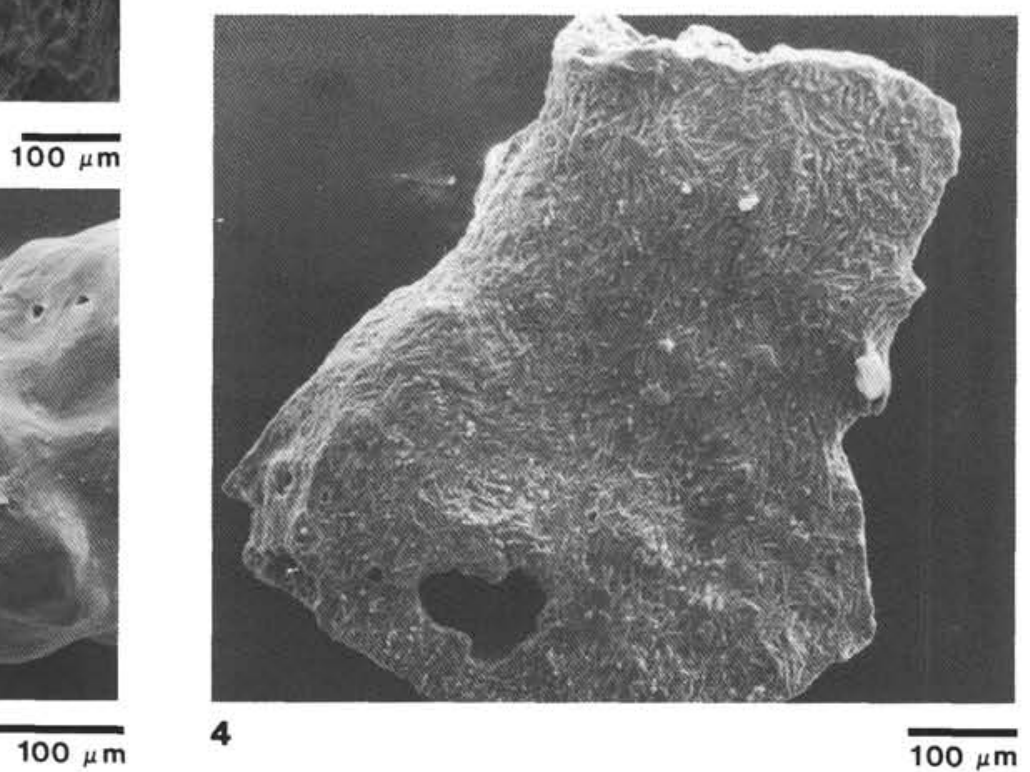

Plate 3. Opaque lapilli occurring in sand fractions. 1. Dark gray lapillus (Sample 650A-14X-CC, 12-14 cm). 2. Red lapillus (Sample 650A-13H-5, 100-102 cm). 3. Black lapillus (Sample $650 \mathrm{~A}-13 \mathrm{H}-5,100-102 \mathrm{~cm}$ ). 4. Red lapillus with filaments of Ca-rich plagioclase (Sample $650 \mathrm{~A}-13 \mathrm{H}-5$, $100-102 \mathrm{~cm})$. 

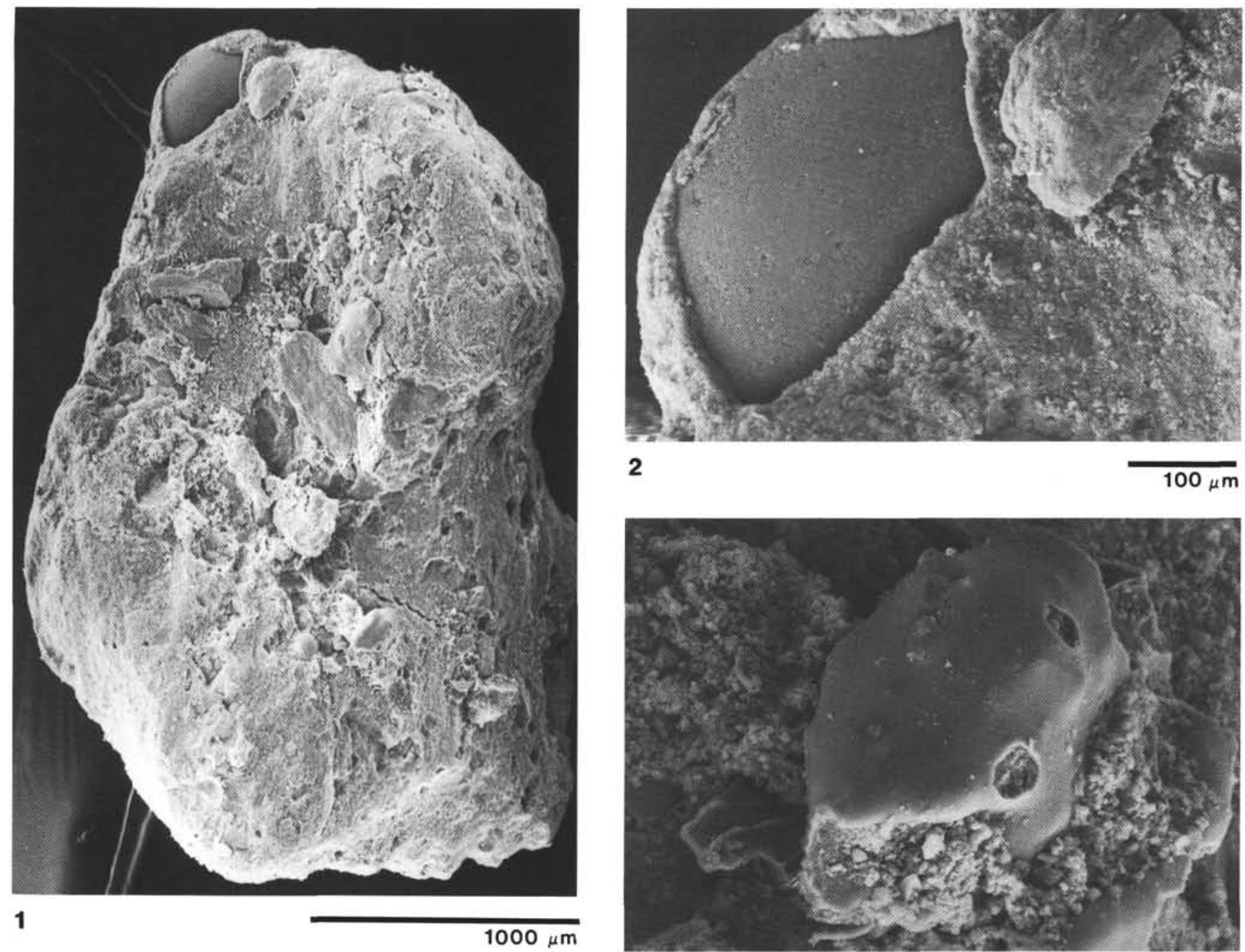

2

$100 \mu \mathrm{m}$

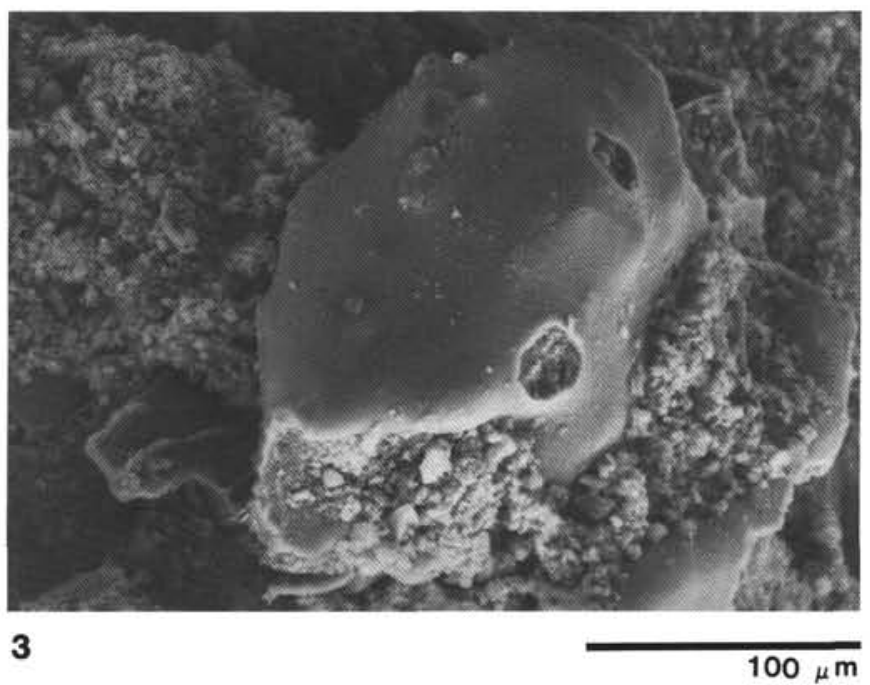

Plate 4. Sediment clast from Sample 650A-13H-2, 100-102 cm. 1. Total view. 2. Internal mold of ostracode (detail from top of Fig. 1). 3. Volcaniclastic component (detail from lower part of Fig. 1). 


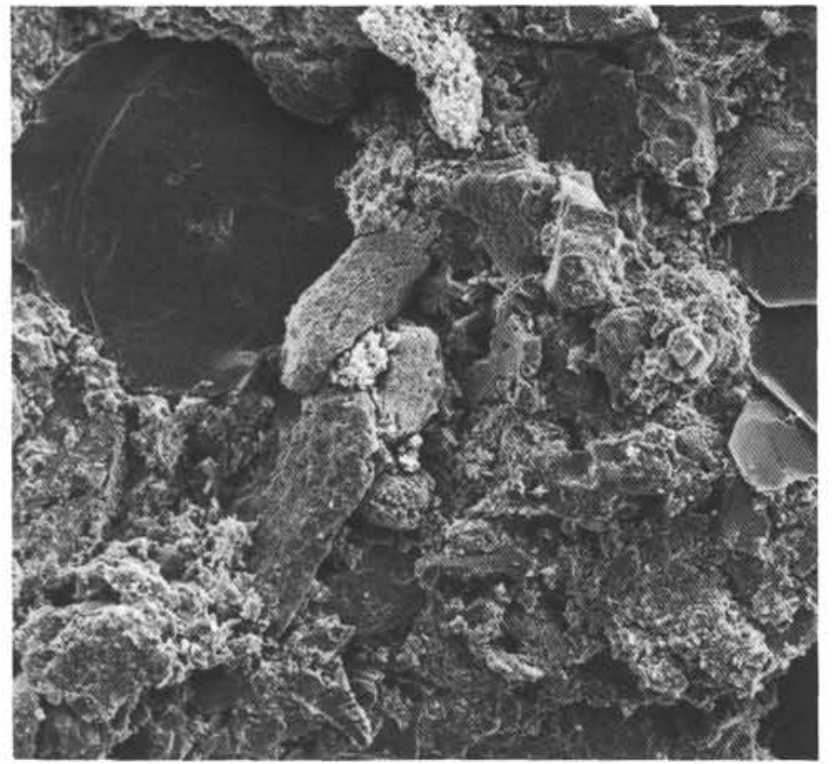

1

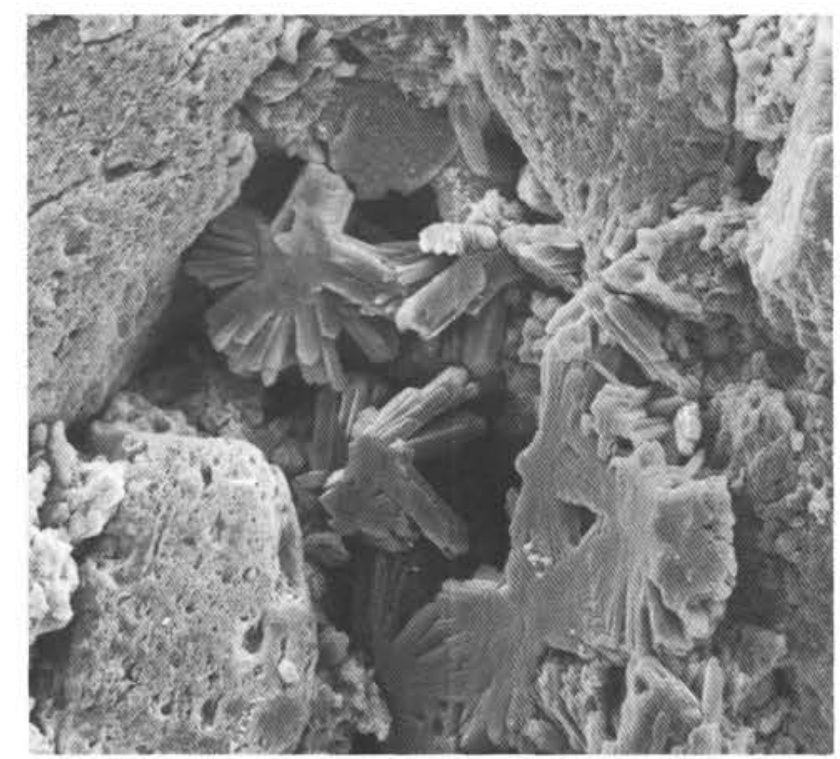

3

$100 \mu \mathrm{m}$

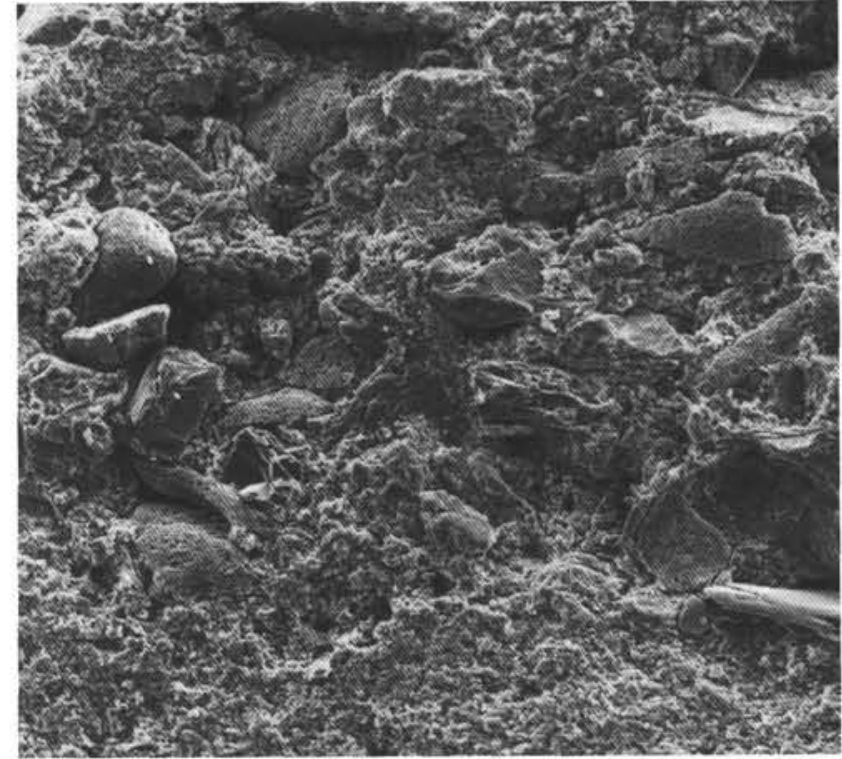

2

$10 \overline{\mu \mathrm{m}}$

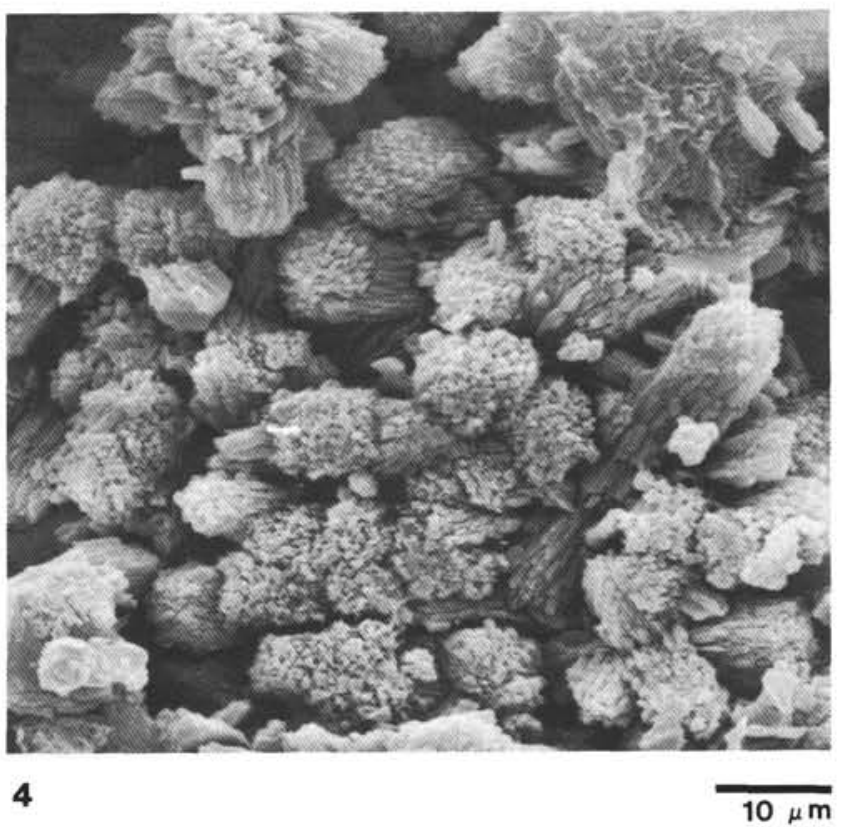

Plate 5. Cemented sediments. 1. Sandstone from Sample 650A-38X-1, 71-73 cm, bedding plane view. 2. Sandstone from Sample 650A-38X-1, 71$73 \mathrm{~cm}$, view perpendicular to bedding plane. Relatively sharp contact between silty and sandy deposits (original orientation unclear). 3. Rosettes of phillipsite crystals growing in cavities originated by complete alteration of volcanic glass (detail from center of Fig. 1). 4. Bundles of zeolite crystals. The sediment consists in the greatest part of zeolite and may have been originally a tephra layer (Sample $650 \mathrm{~A}-42 \mathrm{X}-1,6-8 \mathrm{~cm}$ ). 